\title{
Learning through Play: An Interplay between Early Childhood Teachers' Beliefs and Practice in Aotearoa-New Zealand
}

by

\section{Matthew James}

Submitted to the Victoria University of Wellington

in partial fulfilment of the requirements for the degree of

Master of Education

Victoria University of Wellington

School of Education

2020 


\section{ABSTRACT}

This study explores teacher conception of play and its relationship to children's learning. It also explores how this influenced the role teachers took during play and the way they approached assessment. This case study research involved three teachers across three early childhood education centres in Wellington, New Zealand. Data drawn on included teacher interviews, observations, document, and field notes. Piaget's (1973) and Vygotsky's (1978) Constructivist theories of learning through play provided the theoretical framework informing both the data collection and analysis. Findings suggested that teachers held various conceptions about how learning through play could be practiced and how children learn. These beliefs and assumptions were further influenced by an ad hoc range of contextual factors, including the children's ages, differing centre philosophies and goals. Teachers revealed that the professional development they had been able to access concerning learning through play and assessment had been limited, largely relying on professional development provided by their own centre, discussions with their head teacher, peers, and their own initiative and understanding. This research suggests there is a need to provide on-going professional development to assist teachers to engage with the place of learning in the play-based activities; strategies to assess learning during play activities; and effective documentation. This might help teachers work through the complex and sometimes contradictory ideas about play and children's learning they encountered and the inconsistencies there were at times between their espoused beliefs and practices. 


\section{ACKNOWLEDGEMENTS}

I dedicate this thesis to my family. My sincere appreciation goes to the many people whose guidance, support and practical assistance contributed to this research project. I would especially like to thank the following people:

I sincerely appreciate Maggie Haggerty for her support and guidance throughout the project.

I am indebted to the teachers and their learning communities for participating in this study. I truly appreciate the teachers who volunteered to be part of this research and allowing me to enter their personal space.

Finally, I must acknowledge the support of my family. I dedicate this thesis to my wife, Shoba, our children, Bryan and Shernaia, and my parents, Robert and Sandra. I am incredibly blessed to have such a loving and supportive family to encourage me through this process. 


\section{Table of Contents}

ABSTRACT

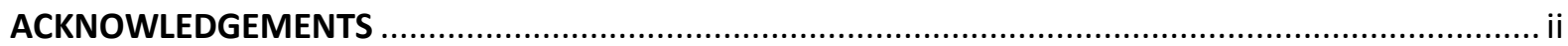

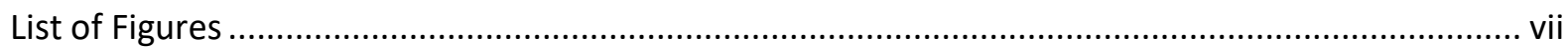

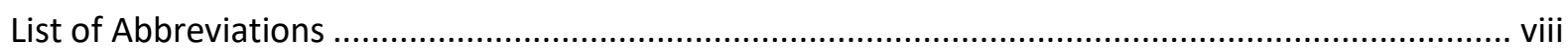

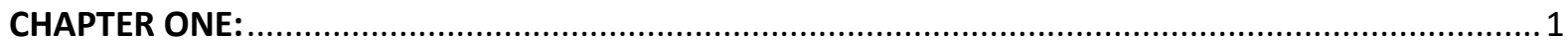

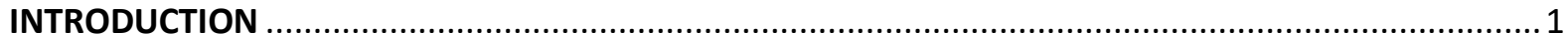

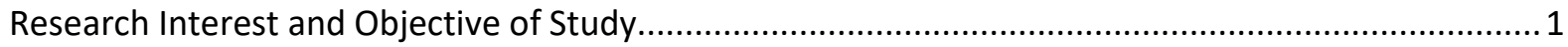

Background of Study: In the New Zealand Early Childhood Context................................................. 2

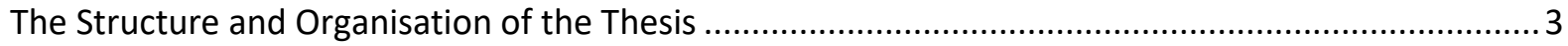

CHAPTER TWO:

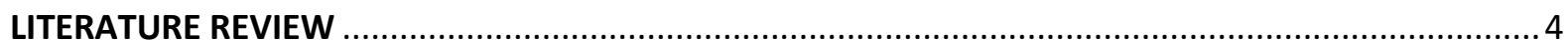

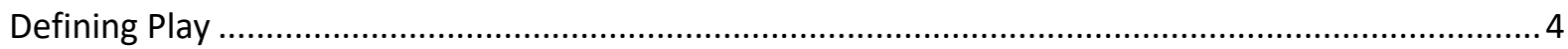

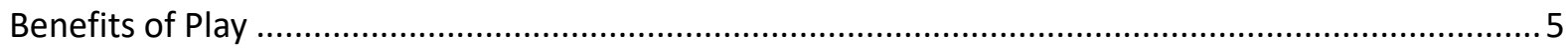

The Paradigm Shift: From Behaviourism to Constructivism ..................................................... 6

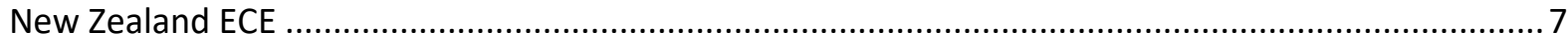

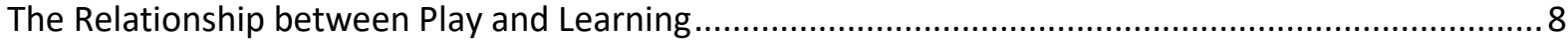

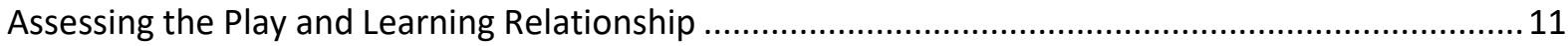

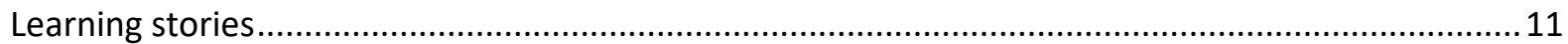

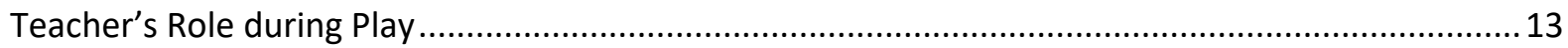

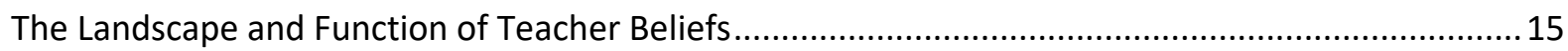

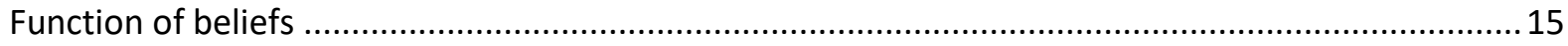

The Relationship between Teacher Beliefs and Practices .......................................................... 16

Issue and Gaps surrounding Learning through Play ...................................................................... 19

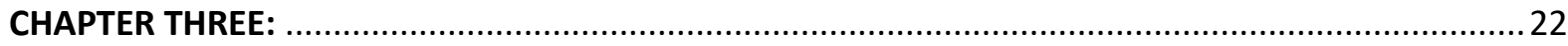

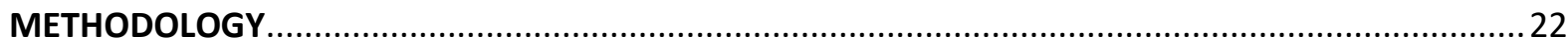

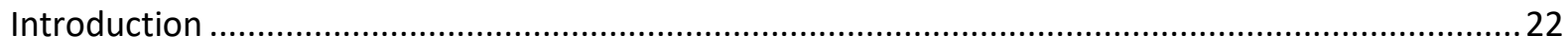

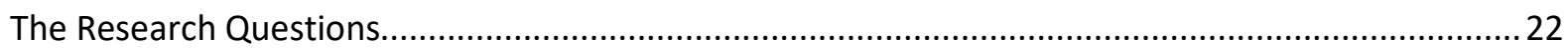

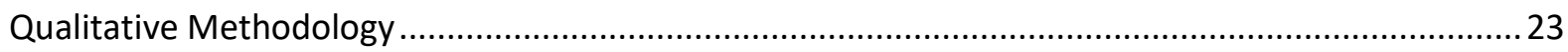

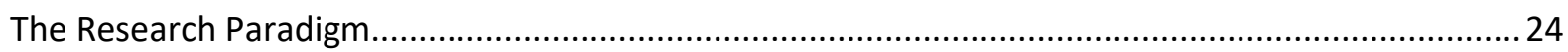

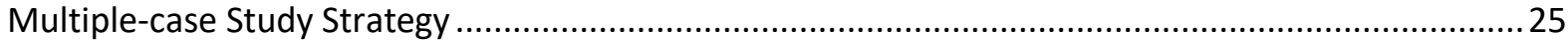

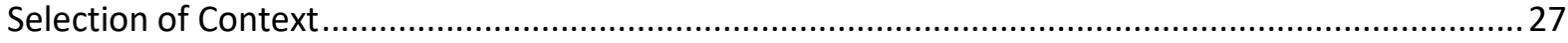

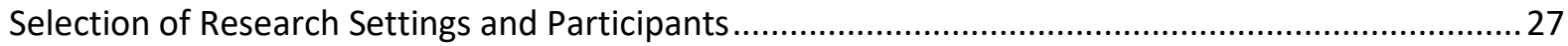




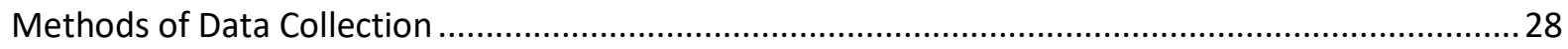

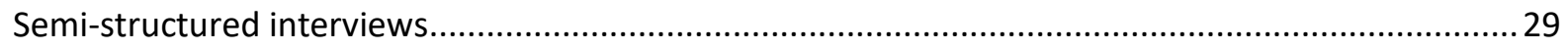

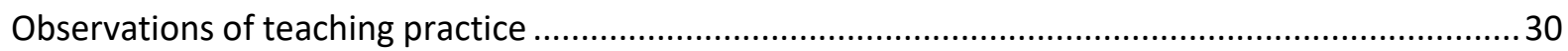

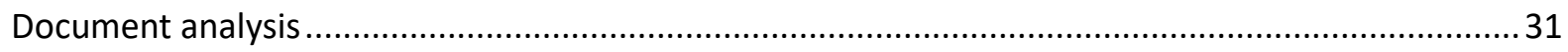

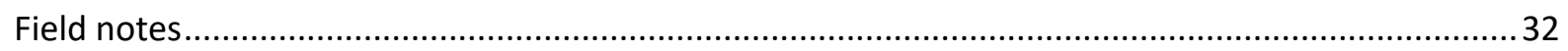

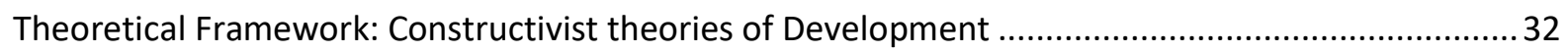

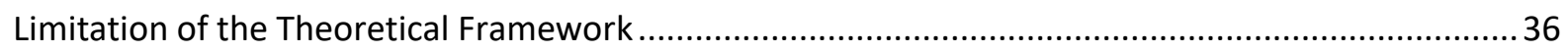

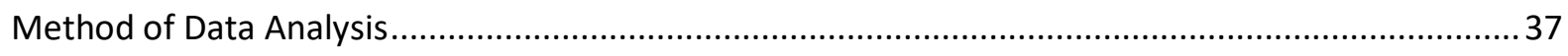

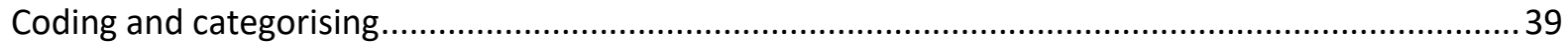

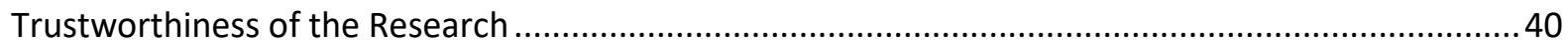

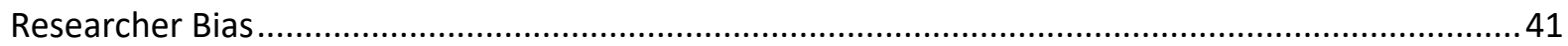

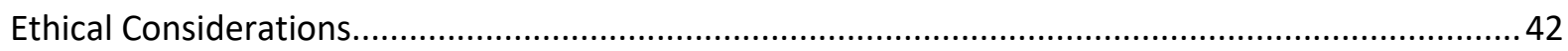

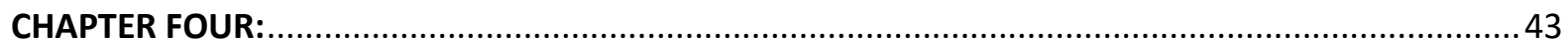

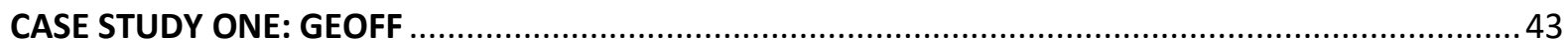

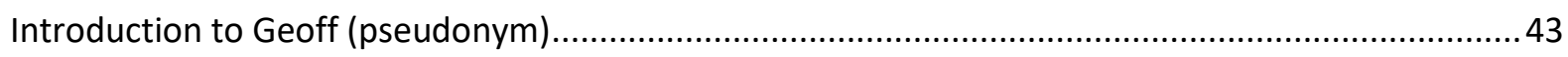

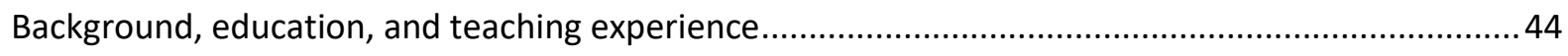

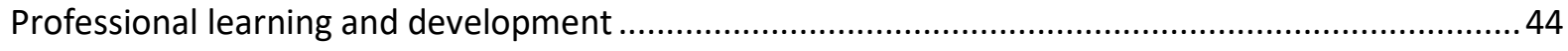

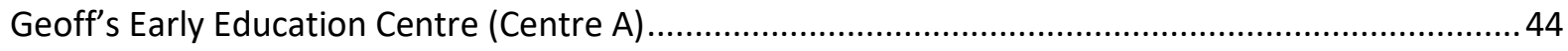

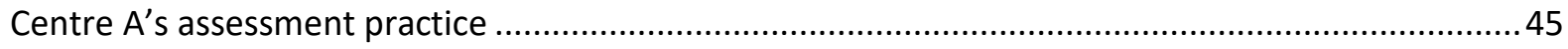

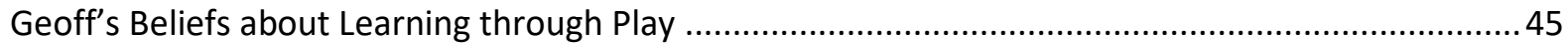

Geoff's understanding of assessing learning through play.......................................................... 47

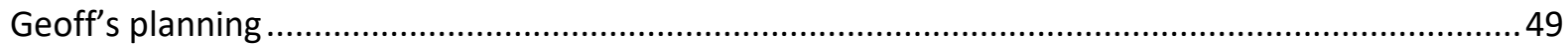

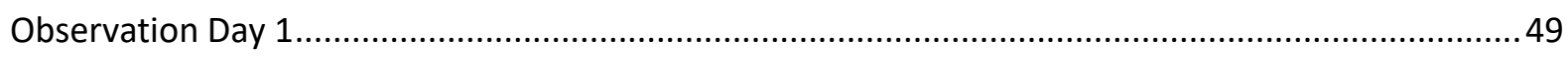

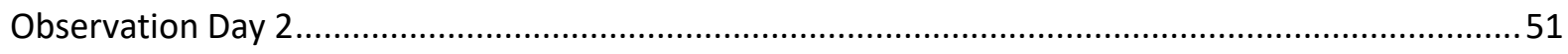

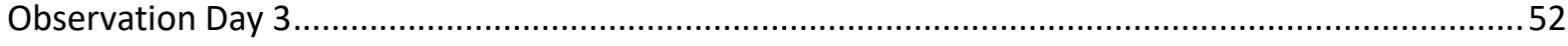

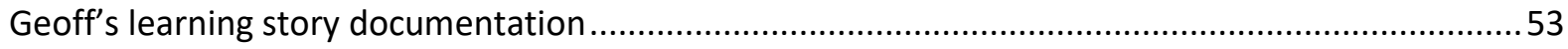

The relationship between Geoff's beliefs and practices ................................................................ 54

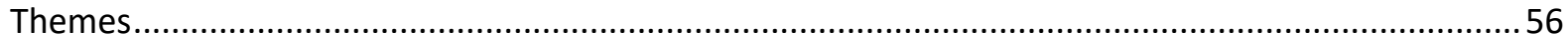

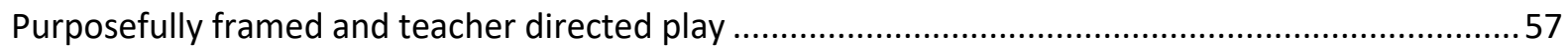

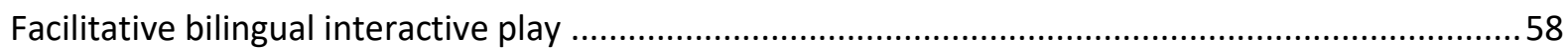

Assessment influences self-exploration of teaching practices ..................................................... 59

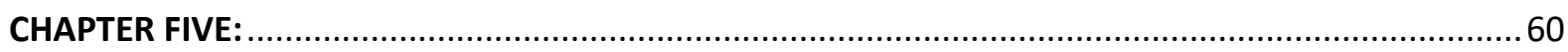

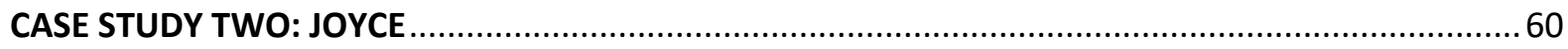




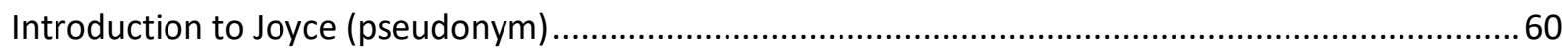

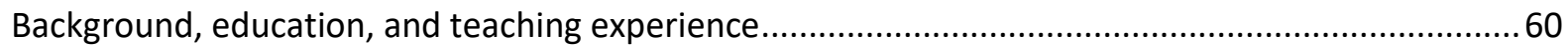

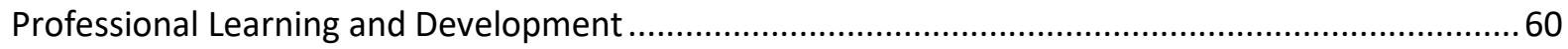

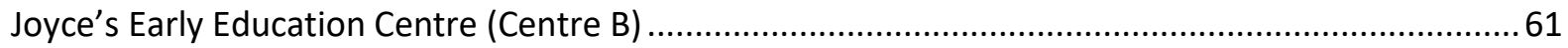

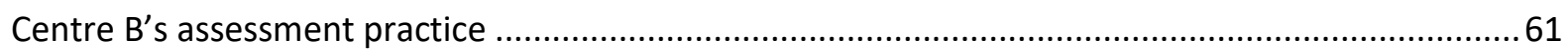

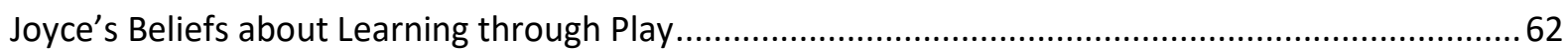

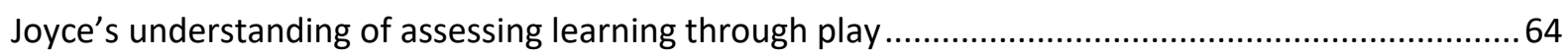

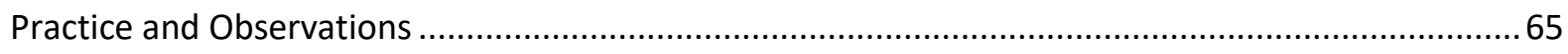

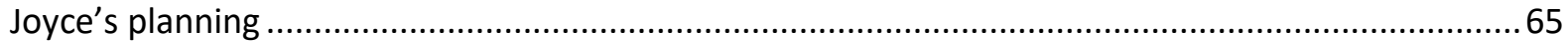

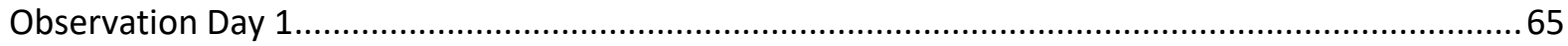

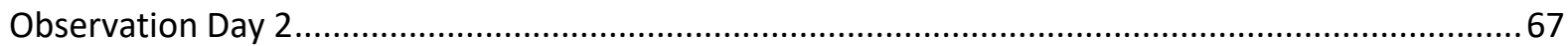

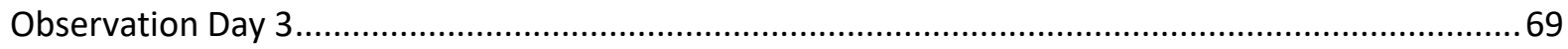

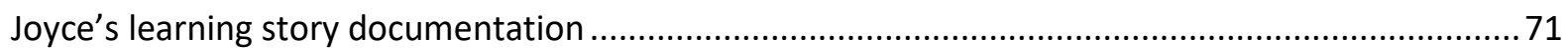

The relationship between Joyce's Beliefs and Practices.............................................................. 71

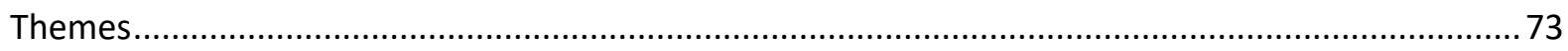

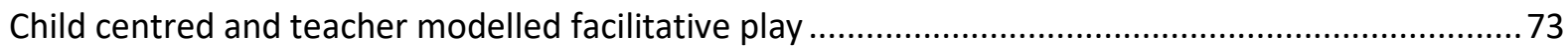

Promote self-regulation through interactive facilitation during play ............................................... 74

Realistic assessment that streamlines relevant information......................................................... 75

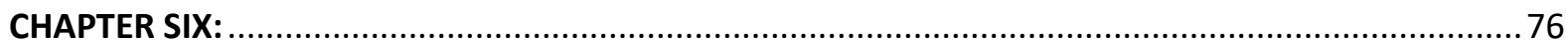

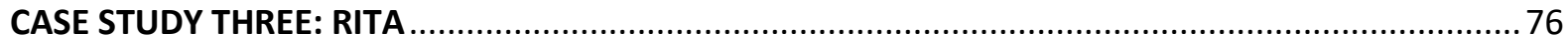

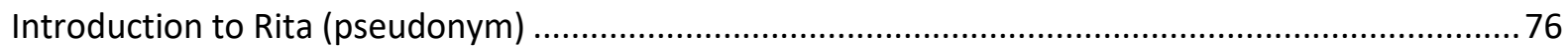

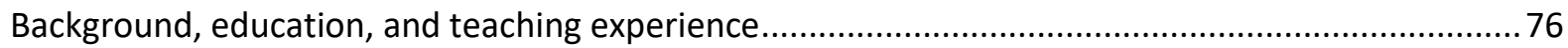

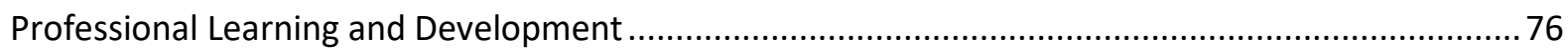

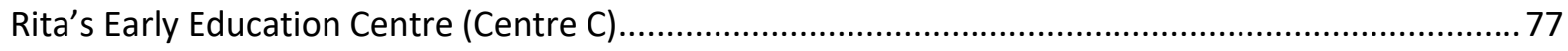

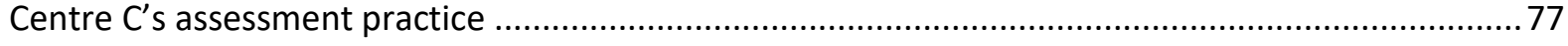

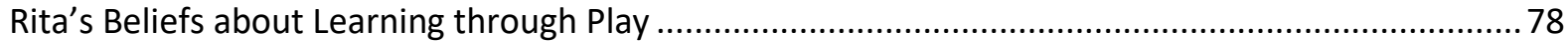

Rita's understanding of assessing learning through play ............................................................... 79

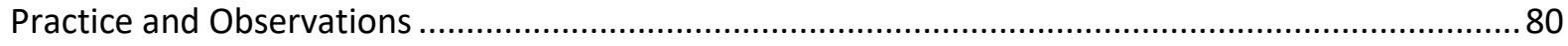

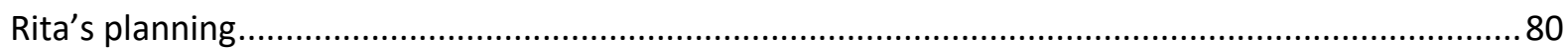

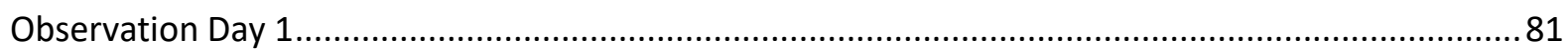

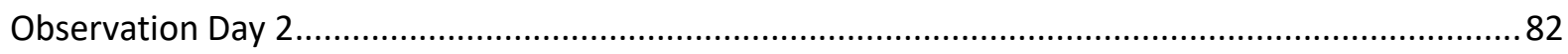

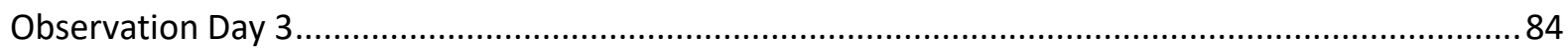

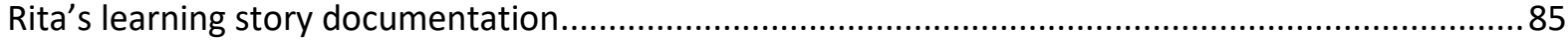




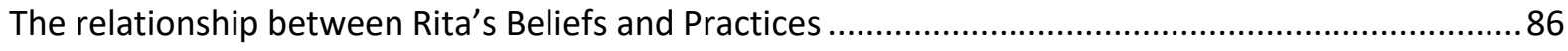

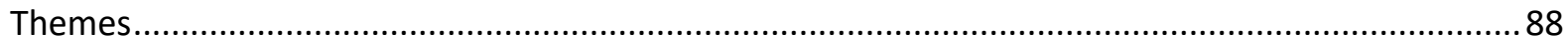

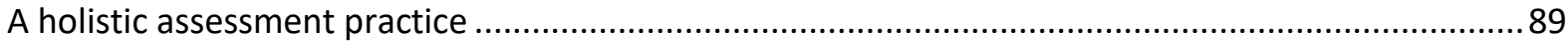

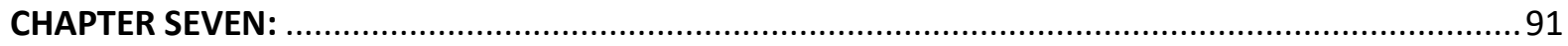

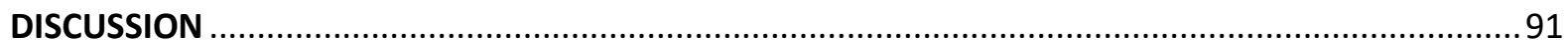

Teachers beliefs about the role of play in children's learning ...................................................... 91

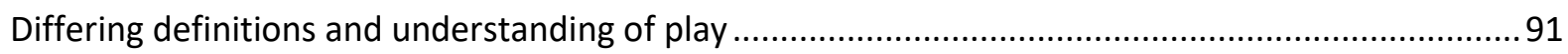

Varied understanding of the role of play in learning ................................................................... 92

The Relationship between Teachers' Beliefs and their Practice....................................................... 94

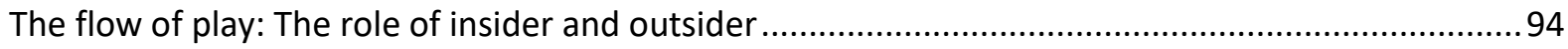

Teacher Roles: Teacher 'guided' or 'child-led' activities................................................................... 96

Diverse understanding about assessment approaches ................................................................ 97

Teacher beliefs connected to distinctive assessment approaches and practice ...............................99

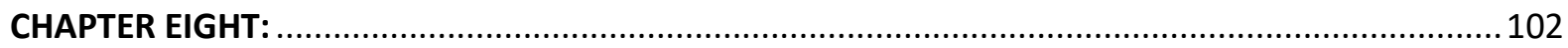

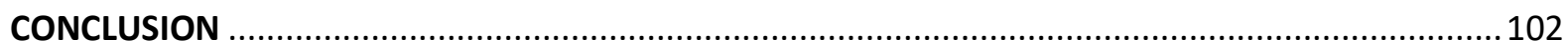

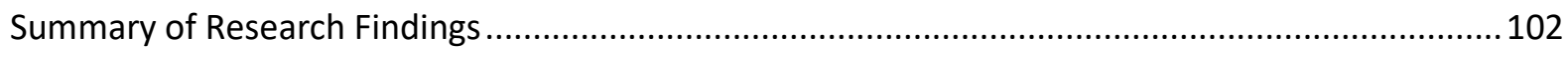

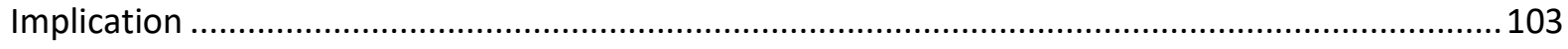

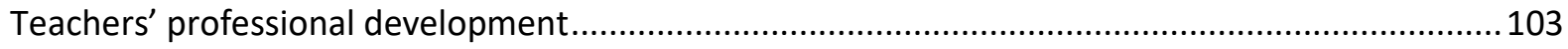

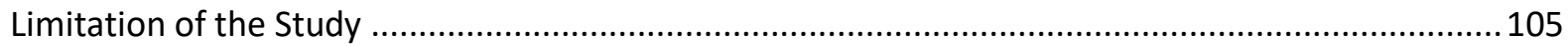

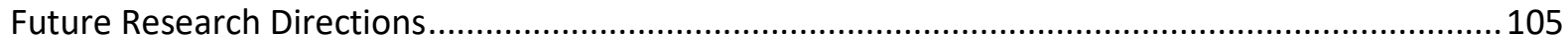

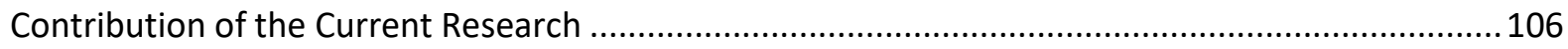

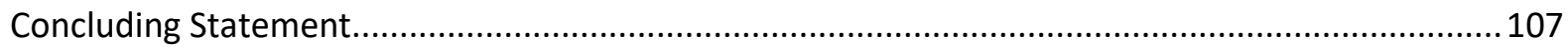

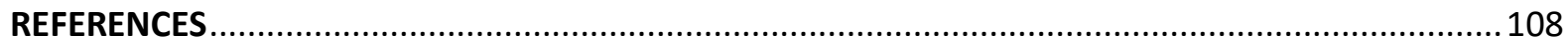

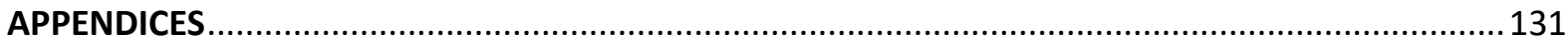




\section{List of Figures}

Figure 3.1: Theoretical framework: Constructivist theories of learning through play

Figure 3.2: Multiple-case study processes and methods of data collection

Figure 4.1: Geoff's reported beliefs and observed practice

Figure 5.1: Joyce's reported beliefs and observed practice

Figure 6.1: Rita's reported beliefs and observed practice 


\section{List of Abbreviations}

Interview data GI Indicates data obtained from Geoff's interview

$\mathrm{JI} \quad$ Indicates data obtained from Joyce's interview

RI Indicates data obtained from Rita's interview

Observation data GO Indicates data obtained from Geoff's observations

JO Indicates data obtained from Joyce's observations

RO Indicates data obtained from Rita's observations

Document data Gdoc Indicates data obtained from Geoff's documents

Jdoc Indicates data obtained from Joyce's documents

Rdoc Indicates data obtained from Rita's documents

Field note data GF Indicates data obtained from Geoff's field notes

JF Indicates data obtained from Joyce's field notes

RF Indicates data obtained from Rita's field notes

Website data GW Indicates data obtained from Geoff's centre's website

JW Indicates data obtained from Joyce's centre's website

RW Indicates data obtained from Rita's centre's website 


\section{CHAPTER ONE:}

\section{INTRODUCTION}

The relationship between teachers' beliefs and practice, specifically regarding learning through play and their approach to assessment, is intertwined and complex (Absolum, Flockton, Hattie, Hipkins, \& Reid, 2009; Black \& Wiliam, 1998; Brown, 2004; Carr, May, \& Podmore, 2000). Information gathered through assessment practice guides early childhood teachers on the next learning steps for children in early childhood education (Ministry of Education (hereafter MOE), 2004a; 2004b; 2011). Hayward (2012) defined assessment as ways teachers observe children's learning, comprehend it, and then make informed decisions.

This study explores early childhood teachers' beliefs about learning through play, and how these beliefs influence their practice and shape their approach to assessment. This chapter provides relevant contextual and background information about learning through play and teacher beliefs. The chapter begins by outlining my interest and position regarding learning through play, assessment of this learning, and how this relates to the early learning environment of Aotearoa/New Zealand. This is followed by a discussion of my research objective. The rationale for conducting research on learning through play and the assessment of the learning that occurs is then given. The chapter concludes with an overview of the eight chapters that make up this thesis.

\section{Research Interest and Objective of Study}

My interest in the research subject stems from my own work within the early childhood sector as a teacher. Learning through play and the documentation of that learning remains a challenging issue among researchers and teachers, in part due to inconsistent definitions of play. Planning a stimulating and inclusive curriculum around 
play interests requires much preparation and knowledge on a teacher's part. In order to extend children's learning and development through play, teachers must be ready to recognise and seize upon teachable moments. It is important that teachers support children's learning and development by providing a wide range of creative and stimulating activities, that engage children of all ranges of abilities. For many teachers, myself included, this can be challenging (Wood \& Bennett, 2000). As an early childhood teacher, I was interested to understand how others in the field interpreted learning through play and how their beliefs about learning through play influenced their assessment practices and the way they assessed children's learning.

\section{Background of Study: In the New Zealand Early Childhood Context}

Te Whāriki, is the authorized early childhood education (ECE) curriculum for all early education settings which came into effect in 1996 and was updated in 2017. It is created on the principle that each setting will weave a curriculum that is responsive to the children and community (MOE 1996; 2017). Te Whāriki provides learning outcomes to be implemented, based on a socio-cultural and holistic perspective (Lee, Carr, Soutar, \& Mitchell, 2012). Within the curriculum, teachers are encouraged to support children's learning and development through play and based on their own interest (MOE, 2017). Learning through play is seen as beneficial to children and helps them develop and refine their skills. The curriculum suggests that teachers incorporate a competence model and promote learning through play that is learner-centred (MOE, 2017).

The curriculum offers wide-ranging principles and objectives to assess children's learning (MOE, 2017). The Kei tua o te Pae ECE assessment resource, the assessment arm of Te Whāriki, includes 20 booklets and 177 exemplars of resources to make visible learning, through the use of narrative assessments, particularly in the form of learning stories (MOE, 2004a; 2004b; 2004c; 2004/2007/2009). This was developed as an 
alternative to standardised assessments that aims to describe children's progress in learning (Carr \& Lee, 2012). Within the curriculum framework, play is positioned as a meaningful way of learning for children (MOE, 2017).

\section{The Structure and Organisation of the Thesis}

This thesis is made up of eight chapters, including an introduction. Chapter two reviews literature related to play and learning, assessment, and teachers' beliefs. It concludes by examining gaps and issues surrounding play. Chapter three outlines the methodological approach to the research, providing the rationale for the methods used. Chapters four, five and six cover the individual case studies of the teacher participants in the study. Chapter seven follows with a discussion of the findings in light of the literature reviewed. Chapter eight summarises the research and explores the implications to practice and future research. 


\section{CHAPTER TWO:}

\section{LITERATURE REVIEW}

\section{Defining Play}

Play is widely viewed as multi-faceted, spontaneous, and unpredictable, and it has been difficult to define and research (Pelligrini, 2013; Wood \& Attfield, 2005). There are many definitions of play. For example, Fromberg (1987) defines play as an act of being symbolic, meaningful, pleasurable, voluntary, and intrinsically motivational, rule governed. Contrastingly, Pellegrini's $(1995$; 2013) definition of play is a disposition the child brings to the activities. Play is described as personally motivating for children, giving significance to activities rather than goals, often occurring through exploration with familiar objects and free from rules, and adapted through non-literal active engagement (Pelligrini, 2013). Wood and Attfield (2005) claim any definition of play should consider the different contexts, and children's needs, interests, and preferences. Defining play or categorising it based on a single factor or event is challenging (Wood \& Attfield, 2005). While researchers generate definitions that reflect the complexity of play through differing theoretical lenses, teachers are left with inconsistent definitions that challenge their understanding of the role of play in children's development and the implementation of a play and learning curriculum (Alcock \& Stobbs, 2019; Pelligrini, 2013; Mueller \& File, 2019; Nuttall, 2003).

Research by Wood and Attfield (2005) found that teachers differ when defining play. Some teachers state that play should be initiated by children, others state that play should be structured by time and that resources are crucial in the learning through play beliefs. Therefore, research reveals that a variety of beliefs and assumptions about the role of play exist within the early education learning environment. 
Benefits of Play

Play has been widely recognised as one of the key tools in enhancing children's learning. Recent studies support the role of play in children's learning and development (Alcock \& Stobbs, 2019; Moore, Edwards, Cutter-Mackenzie, \& Boyd, 2014). During play, children can be regarded as active learners, who learn by doing (Dewey, 1910). Children learn through play as during this activity, children can improve their language acquisition; cognitive, social and physical skills; and their self-regulation of emotions (Lindsey \& Colwell, 2003; Moore et al., 2014; Nuttall, 2003; Saracho \& Spodek, 2006). Early childhood teachers invest time and energy to plan and implement play in their daily teaching and learning activities as it can provide opportunities for children to engage in discovery and inquiry (Aras, 2016; Clark \& Kragler, 2005; Edwards, 2016).

Piaget (1973) described children in pre-school years as being at the preoperational stage of cognitive development, where literacy and numeracy have little meaning for them. However, children at this stage use concrete symbols to represent objects and ideas which indirectly impacts and develops their literacy and numeracy learning (Bodrova, 2008). Categorisation, organisation, putting items into a series, and problem-solving, are important mathematical concepts (Wolfgang, Stannard, \& Jones, 2001). Research evidence suggests children naturally engage in mathematical activities during play (Bjorklund, 2016) and some forms of play are linked with mathematical achievement (Ramani \& Siegler, 2008).

During play, children react to situations through emotions, which are significant in helping them form relationships. Play helps children connect and interact with their surroundings and develop their emotional and social skills (Halberstadt, Denham, \& Dunsmore, 2001). Effective social development is observed through children's appropriate expression of emotions, understanding of peer's emotions and the ability to regulate their emotions during interactions (Halberstadt et al., 2001). As a result, successful peer interactions lead to positive behaviours and also positive engagement with peers (Denham, 1998; Camras \& Halberstadt, 2017). 
Play activities are critical in children's language development (Clark \& Kragler, 2005; Marcon, 2002). The interactions with teachers and their peers help children acquire words and develop their own language proficiency which shapes their future communication skills (Weisleder \& Fernald 2013). Some studies have suggested that teacher engagement through interaction during play is a vital component in enhancing children's language development and the skills required to use them appropriately (Clark \& Kragler, 2005; Tsao, 2008). In addition, scaffolding has been specified as a form of interactive guidance for children during play for effective language learning (Weisberg, Hirsh-Pasek, Golinkoff, Kittredge, \& Klahr, 2016). Further research suggests that children's overall language learning can be enhanced more during play, than during formal, instruction-based language teaching (Stipek \& Weisz, 1981; Stipek, Feiler, Daniels, \& Milburn,1995).

\section{The Paradigm Shift: From Behaviourism to Constructivism}

Two key paradigms that have shaped early childhood curriculum are the behaviourist worldview and the constructivist worldview (Steele, 2005). Behaviourist theory was founded and developed by Watson (1913), Thorndike (1913) and Skinner (1938) and is significant because of its focus on stimulus-response interaction that is observable. The traditional teaching and learning classroom implemented the behaviourist theory, a structured approach with explicit and direct instruction provided to children by teachers (Ertmer \& Newby, 1993). This approach is teacher-centred and led through explanation, where the teacher models each step and provides guidance to children. Within the behaviourist paradigm, the teacher role is autonomous, and students are provided with all the details so there is limited opportunity for discovery (Steele, 2005). Constructivism differs from the behaviourist theory as it is learner-centred, and teachers are facilitators in the learning process (Piaget,1973; Vygotsky, 1967) 
One of the key concepts of the constructivist theory is that learning should be meaningful and connected to real life situations. Teachers influenced by the constructivist worldview build on children's prior knowledge and skills (Vygotsky, 1967). The constructivist paradigm includes a position adopted by Dewey (1966), Vygotsky (1967) and Piaget (1973), which highlights learning as a 'process' where children actively construct knowledge through experiences that are meaningful and important to them (Dewey,1966). Piaget's (1973) theory of psychological development of children stresses the belief that actions, and spontaneous activities develop children's cognitive structures and knowledge construction. Building on Vygotsky's (1967) theory, the concept of scaffolding children's learning through the Zone of Proximal Development (ZPD), suggests that by providing temporary guidance and supporting children's development, teachers should be able to assess children's readiness to move from one level to another though sustained observation and engagement with them (Hedges, 2000).

Within this research, a constructivist worldview has been adopted because ECE in New Zealand emphasises the development of children and their ability to test ideas; modify and build their learning environments; actively engage in problem-solving and thinking, learn by doing and hands-on practice through play (MOE, 2017).

New Zealand ECE

The Te Whāriki curriculum is influenced in part by Bronfenbrenner ecological system of human development and Vygotsky's theory of sociocultural theory (Bronfenbrenner, 1979; Bronfenbrenner \& Morris, 2006; MOE, 2017). The curriculum's key element is children becoming competent and capable individuals with the key principle of empowering children and enabling a holistic learning and development. The curriculum is aimed for children from birth to school entry and focusses on three age 
categories: birth to 18 months (infant), one to three years (toddlers) and 2.6 months to school entry (young child) (MOE, 1996; 2017).

The inclusive curriculum encourages teachers to support children's learning and development as they participate in a variety of activities, including play that stems from the children's own interests (MOE, 2017). It is aimed at supporting, building, and extending the learning children bring with them. Te Whäriki, promotes a learner-centred curriculum that encompasses a competence model which encourages children's activities and engagement in play (Pramling-Samuelsson \& Carlsson, 2008). The curriculum affords a broadly-based framework of principles and outcomes that can be utilised in assessing young children's learning and highlight that children's well-being and development is core during the planning process (MOE, 2017).

The Relationship between Play and Learning

Children are recognised as active participants in their learning and development and the five strands in the Te Whāriki learning and development pedagogy are well-being, belonging, contribution, communication and exploration, with learning stories being one of the methods of assessing the play and learning (MOE, 2017). There has been an emphasis on the abundant teaching and learning possibilities of combining play through authentic experiences that are meaningful to children (Hedges \& Cooper, 2016; Zhang, 2017). Play as a foundation of learning is widely theorised and recognised within the early childhood literature (Brown, 2004; Cutter-Mackenzie \& Edwards, 2013).

There has been a growing trend in education policy to integrate more formal learning approaches in ECE curriculum, specifically in the year heading up to children starting primary school. Various studies have found that ECE settings are under pressure 
to formalise learning goals to meet targeted curriculum requirements and outcomes; United States (US) (Kane, 2016), Australia (Theobald et al., 2015) and China (Wang \& Lam, 2017). Gibbons (2013) argues that such an approach with teacher interventions learning through play becomes too prescribed. One negative effect is that it will counter children's disposition to experiment, explore and interact, qualities that underpin $\mathrm{Te}$ Whāriki (MOE, 2017).

An important proponent of a play pedagogy highlighted in literature and research is the focus on holistic development of learning (Bergen, 2009; Fisher, Hirsh-Pasek, Golinkoff, Singer, \& Berk, 2011). Therefore, understanding the perspective of learning through play has become a significant factor in ECE research over the past two decades (Whitebread, Coltman, Jameson, \& Lander, 2009). Teacher's conceptualisations of learning through play influences the quality and implementation of play experiences for children (Pyle \& Danniels, 2017; Tsai, 2015). Research studies within these area recognise teachers as crucial contributors to children's holistic development (Gimtrova \& Gimtrov, 2003; Whitebread et al., 2009).

Teachers' perspective of learning through play is influenced by curriculum requirements, pre-service teacher training and ongoing professional development (Lynch, 2015; Pyle \& Danniels, 2017). Studies indicate that teachers' enactment of learning through play approach was compromised when there were conflicts between a productoriented curriculum and a process-oriented pedagogy of learning through play (Pyle \& Danniels, 2017). In New Zealand, the ECE curriculum Te Whāriki positions a play pedagogy as fundamental to children's development and learning (MOE, 2017).

One of the key aspects of play and learning is the integration of new knowledge and skills with pre-existing concepts (Sturgess, 2003). This indirectly involves the construction and generation of new and refined skills and knowledge that are montaged 
together, becoming meaningful and familiar to them in real world situations (Roussou, 2004). As a result of the play and learning relationship, play has been embedded into the early childhood curriculum, however, there still exists an overarching complexity in the play and learning relationship.

In a pedagogical play framework, teachers are encouraged to create a rich reality via provision of material for exploration and experimentation in open-ended play (Edwards, Cutter-Mackenzie, Moore, \& Boyd, 2017). When engaging children in play, three play-types commonly used, are open-ended play, modelled play, and purposefully framed play (Cutter-Mackenzie \& Edwards, 2013; Edwards \& Cutter-Mackenzie, 2013). These three play-types are located across a continuum (Moore et al., 2014).

An open-ended play-type is generally seen as being located at the end of the continuum which encompasses the teachers providing children with play experiences with minimal engagement or interaction (Moore et al., 2014). The teacher provides children with "materials suggestive" of a concept and children explore and learn about the concepts (Moore et al., 2014, p. 4). Located in the middle of the continuum is the modelled play. This play-type encompasses the teacher providing play experiences with illustrations, explanations and/or demonstration of resources suggestive of a concept prior to permitting children to use the resources with minimal interaction as a foundation of learning about the concept (Moore et al., 2014).

According to Moore et al. (2014), purposefully framed play is located across the entire spectrum of the continuum. This play-type involves children being provided with play experience through open-ended play, followed by modelled-play and then teacherchild interaction. The teacher in this play-type provides children with materials suggestive of a concept and further opportunities for open-ended play, modelled-play, and interactions (Moore et al., 2014; Wood 2009). 
Assessing the Play and Learning Relationship

Te Whariki suggests that "assessment is both informal and formal" and occurs the moment Kaiako (teachers) listen to, observe, participate with and respond to children who are engaged in everyday experiences and events (MOE, 2017, p. 63). Teachers are encouraged to directly influence the play and learning environment to help children reach immediate and longer-term goals (MOE, 1996; 2017). The concept of listening, observing and participating with the children sees the assessment practice move from teachers as outsiders "obtaining, and interpreting, information that describes a child's achievements and competence" of the first Te Whariki curriculum (MOE, 1996, p. 99) and moving towards engagement with the children.

Many Early Childhood Education (hereafter ECE) teachers consider the strength of Te Whāriki curriculum is that it enables wide-ranging principles and outcomes to be used to assess children's learning and development (Eberle, 2014). Within the New Zealand early education settings, assessment during play is guided by Te Whāriki and the aim of the curriculum is that children progress in competence and confident (MOE, 2017). However, due to the competence model of the curriculum, assessing play and learning is open to different possibilities (Bernstein, 2000; Dalli, 2011). In early childhood education, assessing children's learning during play is a complex and challenging process, however it is the key tool for teachers to identify learning and development (Education Review Office (ERO), 2007; Farquhar, 2003).

\section{Learning stories}

Assessment for learning is emphasised in the Kei Tua o te Pae - Assessment for Learning: Early Childhood Exemplars. Teachers' primary emphasis within the New 
Zealand early childhood education assessment process has been formative focused (MOE, 2004a; 2004b; 2004c; 2004/2007/2009). These publications were intended to increase teachers' understanding of formative assessment and use this knowledge to inform the teaching practices. The original version of Te Whāriki (MOE, 1996) states the purpose of assessment was to provide "useful information about children's learning" and "development to teachers, children and their families" (p. 29).

ERO $(2007 ; 2013)$ states that while there is no formal method of assessment, early education centres often utilise learning stories which are a narrative form of assessment. For example, in the New Zealand early childhood context, learning stories were designed to capture the formative assessment aspect of children's learning but they can be also utilised for a summative purpose, to make judgements (Carr, 1998a; 1988b; 2001). The learning story approach emerged as a result of wanting to create an authentic assessment tool and capture children's' learning outcomes (Carr, 2001; MOE, 2017). As a learning story documents a child's learning and competence through narratives and photos, it is regarded as an assessment tool (Carr \& Lee, 2012). These learning stories "tell and retell stories of learning and competence, reflect on the past and planning for the future" (Carr \& Lee, 2012, p.2). The Te Whāriki framework purposefully avoids providing a road map or format of writing learning stories, so that teachers can find their own meaningful ways of assessing children's learning (MOE, 2017).

Teachers' observations are one form of assessment in early education that enables the teacher to understand each child individually (Drummond, 1995). For a teacher to fully understand children's development, it is crucial for teachers to be observers during play and learn about the children's mindsets, beliefs, and development. Therefore, it is important for teachers to collect assessment data from children within a natural setting through anecdotal notes, video recording and photographs (MOE, 1996; 2017). 
Teacher's Role during Play

Hadley (2002) suggested there are two types of teacher engagement during play: outside or inside the flow. Teachers who are outside the flow, may prompt children to reflect, which leads to modification and extension of play (Hadley, 2002). Contrastingly, teachers who are inside the flow take part in the play as a participant and communicate directly with the children. Whatever flow the teacher takes on, they play an important role during play- based learning, such as an observer, note-taker, manager, facilitator, mediator, or participant (Jones \& Reynold, 1992). In addition, how teachers promote play is influenced by their beliefs, practices, and settings (Barkatsas \& Malone, 2005; Hadley, 2002; Sherley, 2011).

Interactions during play are important for children's cognitive learning. Rogoff (1993) suggests that during play, a teacher's role should be supporting or facilitating to guide and organise activities which result in learning. However, teachers' and children's roles during play have been debated as the 'guiding' perspective is seen by some researchers as teacher-led and directed (Rogoff, 1993). The argument here is that the teachers should not take on a leading role as there is a risk of the children's initiative and interest being overlooked, but rather take on a shared role that complements learning through the play process (McArdle, 2001; McArdle, Grieshaber, \& Sumsion, 2019; Wood 2007).

Research has indicated that the role teachers take in play activities is dynamic and dependent on the types of play with which the children are engaged. If it is an outdoor play type, teachers may adopt a more supervisory role with structured activities than an indoor type of play which requires teacher to possibly take on a facilitator role (Miller \& Smith, 2004). The teacher's role can be placed within a continuum of teacher participation ranging from an authoritative role as an adult transmitter of knowledge, to an insider 
(Miller \& Smith, 2004). Some US research shows that a facilitator role is the most predominant role adopted by early education teachers (Moon \& Reifel, 2008; Wood, 2009). The researchers described early childhood teachers in US as being facilitators during play, for example, setting up the play environment, materials and props so that children are free to choose what and how they want to play (Moon \& Reifel, 2008).

Many policy makers and teachers consider one of the key strengths of Te Whāriki is that it enables early childhood teachers to plan the curriculum around children's interests, an approach that is entirely effective in supporting children's learning (MOE, 2017). Contrastingly, Blaiklock (2018) suggests that the non-prescriptive nature of guidelines regarding programme planning in Te Whāriki is a 'gap' and that early childhood centres are unable to incorporate play effectively into their programme planning. He goes on to argue that sometimes this leads to a narrow, imbalanced view of children's interests, stemming from a lack of understanding or from teachers' bias regarding the importance of children's play and its relationship to learning (Blaiklock, 2010; 2018). Other researchers argue that teachers need to ensure that their knowledge of children's interests, learning and development is current, and that this knowledge is crucial for children's learning during play (Blaiklock, 2013; Farquhar, 2012; Hedges \& Cooper, 2016; 2018).

Another significant aspect for successful implementation of play in New Zealand ECE is teachers' professional knowledge. Of the utmost importance, is teachers understanding and utilizing children's interests as a framework for teaching and learning through play activities (Carr, 1998a; 1988b; 2001; Carr \& Lee, 2019). Hedges and Cooper (2018), state that all early childhood teachers should hold full qualifications and that attention should be given to theorising more complex understandings of how to combine teaching, learning and play (Lee, Courtney, McGlashan, Neveldsen, \& Toso, 2019; Kane, 2016). A number of researchers have argued that building such knowledge and skills can be achieved through robust teacher training programmes for trainee teachers, and 
through professional development courses (Hedges \& Cullen, 2005; Mitchell, Wylie, \& Carr, 2008), specifically in the New Zealand ECE context (MOE, 1996; 2017).

\section{The Landscape and Function of Teacher Beliefs}

Teachers' beliefs play a crucial role in teachers' assumptions about what learning is (Pajares, 1992; Richardson, 2003). There is a body of evidence that teachers' beliefs work as moderators to the success or failure of the implementation of play-based learning (Vartuli, 1999; McCarty, Abbot-Shim, \& Lambert, 2001). There is wide-spread acknowledgement that teacher beliefs influence practice and implementation of play (Hedges, 2011; Hedge \& Cassidy, 2009). Teachers' beliefs about children's learning and development is an important factor in ECE. Many teachers report that play contributes to children's social, cognitive, emotional, and linguistic development. Teachers' beliefs combined with their pedagogical knowledge can either expand or limit children's development and learning during play-based activities (Parker \& Neuharth-Pritchett, 2006).

\section{Function of beliefs}

Beliefs have two functions: one helps an individual define and understand themselves and their surroundings, and the other guides their decision-making (Pajares, 1992). In addition, teachers not only hold individual beliefs about their surroundings, but also hold beliefs about themselves, for example about their capabilities. These beliefs lead to the teacher's choices of tasks/activities, persistence, and their level of success (Oppermann, Brunner \& Anders, 2019). Teachers' beliefs are argued to be the most significant factor in teachers' learning through play decision making, a strong determiner in their practice (Bandura, 1986); as well as highly resistant to change. For example, long 
held beliefs can be difficult to be reformed (Pajares, 1992), or changed through argument, reasoning, or logic (Fang, 1996).

Early childhood teachers enter their teaching profession with pre-existing beliefs that have been built since they were learners. Studies have found that the time teachers spent as learners, pre-service and in-service, develops their beliefs. These beliefs act as filters where knowledge and information are interpreted, acted upon, adopted, or adapted, and ideas challenging their pre-existing beliefs are often rejected (Thomas \& Pederson, 2003).

The effect of teachers' beliefs on their practice has been a focus of many research studies (Hedge \& Cassidy, 2009; Parker \& Neuharth-Pritchett, 2006). Teachers' beliefs are considered as a 'construct' of their thoughts that needs to be further researched (Pajares, 1992). Investigation into teacher beliefs and the influence of these beliefs on their practice will provide an in-depth view of their play-based approaches in the early childhood education in New Zealand. Therefore, this research focuses on the beliefs and practice relationship of early childhood teachers in New Zealand specifically in the learning through play curriculum.

\section{The Relationship between Teacher Beliefs and Practices}

Teacher beliefs can be defined as the interrelationship between teachers' assumptions about children and how they learn, their attitudes towards children, and values they hold in relation to education and children (Pajares, 1992). Zeichner and Gore (1989) explain that a compilation of beliefs and attitudes shape the teacher and serve as a filter through which their instructional decisions are informed, conserved, and transformed. Some empirical studies suggest teachers' beliefs are stable and resistant to 
change (Kagan, 1992). Others suggest teachers espoused beliefs and practice are not consistent (Fang, 1996). The most plausible explanation for this was that unpopular, tacit, and contradictory beliefs continue to impact their practice (Kagan, 1992). An alternative explanation has been that core central beliefs held by the teachers are resistant to new beliefs (Pajares, 1992).

Some researchers argue that teachers' belief systems are resistant to change, therefore, professional learning and development are ineffective in altering their beliefs (Pajares, 1992; Richardson, 2003). Research in early education indicates that teachers have strong, established belief systems that developed as a result of their personal teaching experience and new learning experience such as professional learning and development. Breffni (2011) found that curriculum or course-related professional development improved teachers' knowledge but had minimal impact on changing their beliefs.

Other studies argue that teachers' beliefs systems are transformative (Parke \& Neuharth-Pritchett, 2006; Speer, 2008; Vartuli, 1999). Several studies on ECE found professional development effective in altering teachers' beliefs (Isikoglu, 2009; Vartuli \& Rohls, 2009). These studies specifically targeted teachers' reassessment of their beliefs as a result of new learning, understanding and experiences. For example, Vartuli \& Rohls (2009) followed a cohort of pre-service early education teachers from their initial education programme, induction and one year after employment. These teachers' learning comprised of theoretical instruction and ongoing practicum opportunities. The teachers were challenged to explore ideas and perceptions from various perspectives. They also reflected on how their preconceived beliefs changed over time. The findings indicate that it was important for educators to support teachers in exploring their beliefs based on new learning through professional development. 
A complex relationship exists between beliefs and practice, with both extrinsic and intrinsic factors seen as having an influence. A variety of factors that may be intrinsic to an individual teacher were identified by Charlesworth, Hart, Burt and Hernanadez (1991) and others. These factors include beliefs, knowledge (both theoretical and practical), principles, and attitudes (McLachlan et al., 2017; Smith \& Shepard, 1988a; 1988b; Stipek \& Byler, 1997). Extrinsic factors are often more visible and observable, and include formal education, physical working environment, experience, and parental expectations (Claxton \& Carr, 2004; Hedges; 2011; 2014; Hedges \& Cooper, 2016; 2018; White et al., 2008). Other research points towards outside factors which may create an imbalance between beliefs and practices. Research has found that teachers may not always feel able to put into practice a curriculum which aligns with their beliefs (Durden \& Dangel, 2008; Stipek \& Byler, 1997; Stipek et al.,1995).

Teachers' subject and curriculum knowledge is seen as fundamental when fostering play (Hill, Cowie, Gilmore \& Smith, 2010). For example, McLachlan-Smith (1996) found that there was a relationship between teachers' beliefs and supporting children's literacy learning based on the draft Te Whāriki (MOE, 2003). Findings from case studies, interviews, observations, and document analysis revealed that how the curriculum was being interpreted and implemented was based on the teacher's beliefs and interpretation of the curriculum. Harris (2016) points out that the role of play within the early learning has been increasingly questioned, due to augmented strains and demands for earlier education and misinformed beliefs about play-based pedagogies. Teachers are influenced by their beliefs when adopting, adapting, or rejecting new pedagogical concepts into their teaching (Vartuli, 1999; McCarty, Abbot-Shim, Lambert, 2001; Wang, Elicker, McMullen \& Mao, 2008).

New Zealand research on teacher's beliefs and practices reveals inconsistencies between beliefs and practice when transferring knowledge into practice (Blaiklock, 2013; Farquhar, 2012; Hedges \& Cooper, 2016; 2018; McLachlan et al., 2017; McLachlan, 2018; Zhang, 2017). The differing philosophies and theoretical conceptualisation of 
learning through play and the various studies conducted about learning through play and assessing learning as well as teachers and children's role during play further complicates the current understanding and practice. Thus, there is the need to investigate New Zealand ECE teachers' beliefs and practices about learning through play.

Issue and Gaps surrounding Learning through Play

There is strong ideological and theoretical support for a learning through play curriculum in ECE (McLachlan, 2013; Saracho, 2015). Nevertheless, evidence suggests that teachers find it challenging to translate learning through play into practice. The educational potential of play is not realized fully in the early education curriculum (Hedges, 2000; Wood \& Attfield, 2005). However, the role, purpose and value of play has been debated, especially the issues of contexts, validation and endorsement of play within the curriculum, and specifically, the relationship between playing, learning and teaching (Bennett, 1997; Smith \& Pellegrini, 2008; Wood \& Attfield, 2005).

These pro- and anti-play ethos arguments have ensured that play remains the subject of educational discussions, research, and policies (Hedges, 2000; Wood \& Attfield, 2005). The trend of promoting play pedagogy within the early childhood education framework has been growing worldwide. This indirectly has influenced and challenged early childhood teachers to understand the meaning and value of play and to implement it in their practices (Leggett \& Ford, 2013). Understanding of play has progressed since the 1990s with wide-ranging recommendations about the types of play to be promoted, and the role of teachers in implementing play pedagogy within the early learning environment. In recent times, the focus has shifted from academic achievement to a learning through curriculum, with practices shifting from didactic models to those which see the teacher in a more active, participatory role (Bodrova,2008; Halberstadt, Denham, \& Dunsmore, 2001). 
These varying recommendations have created confusion and impacted on practice in different ways for ECE teachers. Research found that teachers who recognised the learning and development value of a play-based curriculum were facilitators during the play process, while teachers who valued academic benefits were active teachers who directed the play process (Pyle \& Danniels, 2017). In addition, teachers found it challenging to identify the academic benefits of play; lacked knowledge and skills through training and/or professional developments on play; and did not recognise the importance of engaging in direct instruction to achieve the outcomes (Howard, 2010; Leggett \& Ford, 2013).

A shallow understanding of children's interests and patterns of play, along with increased pressure on educators to produce academic outcomes for children, can also adversely affect the implementation of play-centred curricula. Hedges and Cooper (2016; 2018) state that constrained interpretations of play-focused pedagogy in ECE have been maintained through deep-rooted, child-centred beliefs and current prioritisation of educational outcomes. Cooper and Hedges (2014) found that teachers saw themselves and have been positioned as observers of children's play, due to long-held views of childcentred play, which may have discouraged educators from engaging with children at a deeper level. Children's interests are fundamental when planning play activity within the New Zealand curriculum. Research indicates that many teachers try to accommodate children's interests when incorporating learning through play (Cooper \& Hedges, 2014; Hedges \& Cooper, 2016; 2018), although researchers agree there has been a gap in understanding children's interests as the structuring of play is adopted into the learning environment.

This gap may be due to a lack of adequate research on how teachers can best support children's learning through play. Hedges (2014) points out the dearth of academic 
literature that enables teachers to make decisions regarding whose and which interests to follow when it comes to programme planning. Ministry of Education (1993; 1996) and Hedges (2013) raise the question of how understanding of children's interests and play might support teachers as they work towards constructing a curriculum alongside children within Te Whāriki framework. Another challenge is that when teachers rely on their own experiences and those of peers to learn about good assessment approaches, there may be gaps in their understanding and ability to support the development and quality of their own practice (Reynolds, 2007). 


\section{CHAPTER THREE:}

\section{METHODOLOGY}

\section{Introduction}

This chapter presents the research questions followed by the research methodology utilised in this research. The next section describes the research paradigm and the philosophical context in which the research is situated, justification for utilising an interpretive paradigm and the rationale for using a qualitative methodology. This is followed by sections on the justification for using a multiple-case study approach and the rationale for the selection of context, settings, and participants. The following section describes the method of data collection which include semi-structured interviews, observations, document analysis and field notes. Within these sections the reasoning behind the methods and procedural information are then explained.

The subsequent section focuses on describing the Constructivist theoretical framework and the limitations of the framework. This is followed by the section on the method of data analysis and the coding and categorising process. Issues of trustworthiness of the research, researcher bias and ethical considerations are then addressed in the following sections.

\section{The Research Questions}

The study aimed to answer the following research questions: 
How do early childhood teachers' beliefs on learning through play impact their approach to assessment?

More specifically, the research was driven towards answering the following questions:

- What beliefs do early childhood teachers hold about the role of play in children's learning?

- What role do teachers' beliefs on play have in the assessment of children's learning?

My research focused on ECE teachers, and their learning through play beliefs and practices. I drew on a qualitative, interpretive paradigm to answer the research questions.

\section{Qualitative Methodology}

This research is situated within a qualitative research methodology and an Interpretivist paradigm (Denzin \& Lincoln, 2011). I drew on the five structures of a qualitative approach as suggested by Merriam (2001). The goal is extracting understanding and meaning, the researcher is main tool of data collection and analysis, using fieldwork, an inductive analysis, and rich descriptive findings. The qualitative interpretivist paradigm of this research complements the existing body of literature on learning through play in ECE with semi-structured interviews and teacher observations as essential data collection methods to elicit teacher beliefs and practice relationships. This emphasised teachers' beliefs and interpretations of their beliefs and perception of play. The "thick descriptions" of teachers as the knowledgeable participants, enhanced by different perceptions and experiences, offered multiple meaningful realities of beliefs 
and practices of play-based learning among the early childhood teachers (Stake, 2006; 2010).

Data collection methods, including semi-structured interviews and observations, provided in-depth exploration into relationship between teachers' beliefs regarding learning through play, and their practice. This provided embedded opportunities for teachers' beliefs to be investigated that were context- and content- related (Delamont, 1992). As any research method has flaws, the interviews relied on teachers explaining their beliefs about learning through play and assessment, a process shaped by the research itself. The interviews were complemented by other data collection methods such as observations, document analysis and field notes.

The Research Paradigm

A paradigm is defined as a worldview or means of "making sense of the complexities of the real world" (Patton, 2002, p. 69), or "logically related assumptions, concepts or propositions that orient thinking and research" (Bogdan \& Biklen, 2007, p. 24). The choice of methodology for this research is influenced by beliefs on how the world should be researched and comprehended (Denzin \& Lincoln, 2011). This is driven by both the ontological and epistemological beliefs, that is the research paradigm, a framework or set of beliefs that influence decision-making (Denzin \& Lincoln, 2008; Schwandt, 2000).

As a researcher, I position myself within a constructive-interpretive paradigm (Denzin \& Lincoln, 2008) because I hold the perspective that educational research involves individual behaviour that is complex and individualised by personal choices (Cohen, Manion \& Morrison, 2007). Individuals construct their own meaning in real life 
situations as a result of their interaction with the world, therefore, creating meanings in different ways even when it is in relation to the same phenomenon. An Interpretivist paradigm provided the best lens for this research as ontologically the early childhood teachers would bring multiple, valid descriptions and explanations about learning through play among children. Epistemologically, the teachers in this research are shaped by and shape their teaching environment as experts.

Methodologically the interactions teachers have during their teaching and practices are valuable and subjective as Creswell (2009) indicates individuals pursue comprehension of their world through "development of subjective meaning of their experiences which are varied and multiple" (p. 8). In addition, Stake (2010) states that the interpretivist believes that there are multiple interpretations that all contribute to a richer, more multidimensional understanding of a phenomenon. This was evident during data collection; each teacher in the early childhood education carried their own set of beliefs and practices about learning through play from their teacher training education, experience, and their current teaching environment. As a result, the interpretivist paradigm of understanding the phenomenon assisted me in gaining insight into their beliefs and practice.

\section{Multiple-case Study Strategy}

The strategy I employed for this research was a multiple-case study approach. Denscombe (2007) defines case-study research as the exploration of instances of a phenomenon in order to provide a detailed view of events, relationships, encounters, or processes. In this research, each case is an investigation of a teacher's understanding and beliefs about play, which enabled the differences within and between cases to be explored to illustrate the same phenomenon (Creswell, 2007). 
The strength of a qualitative case study research is in its small samples that enable in-depth findings (Denzin \& Lincoln, 2011) that provide "rich, thick description" of a phenomenon (Merriam, 2001, p. 29). The research participants were chosen by selective sampling of three cases to be studied in-depth, to gain insight into the phenomenon. The three cases for this multiple-case study presented "literal replication" (Yin, 2009, p. 54) that enabled me to compare and contrast the cases in-depth. The conclusion of one case can be compared and contrasted with other cases to provide robust findings of a phenomena as the cases selected, the methods of analysis, and the topic being researched, are similar. This is the advantage of utilising multiple-case study as a strategy to explore teachers' understanding and beliefs about learning through play, the findings cannot be generalised (Stake, 2006; 2010). Although there are only the cases selected, there are multiple possible variations operating in different contexts and that precludes generalising.

The data collection process included semi-structured interviews with each teacher, observations, post-observation interviews, follow-up emails, analysis of documents and field notes. The key interest was on individual teacher's beliefs and practices during learning through play. The data collection process enabled me to illustrate and interpret each teacher and their situational distinctiveness and provide unique viewpoints of the same phenomenon (Creswell, 2007).

The interpretive-qualitative multiple-case strategy of this research adds to existing to literature by providing contextual insights or the natural context of the phenomena researched. The interpretations of this research are filtered through the personal worldview of the researcher, subjective while open to the researcher's values, background, experiences and understanding (Creswell, 2007). However, the issues, constructions, analysis and the context value of the research focus on attaining important 
results (Denzin \& Lincoln, 2011) influenced by the constructivist theories of development as a theoretical framework (Piaget, 1973; Vygotsky, 1978).

\section{Selection of Context}

The focus of this research is on assessing children's learning and development through play activities within ECE in New Zealand. In ECE planning, incorporating and documenting children's play-based learning to help children progress has been important. There has been a wealth of information and research readily available on learning through play and its benefits.

\section{Selection of Research Settings and Participants}

Purposeful sampling was utilised as I wanted to select teachers working in ECE centres and Kindergartens in the Wellington region. My research interest was in teachers working within the early childhood setting. Contacting teachers was done through emailing and getting permission from centre managers, who then decided if they wanted to participate in this research. The centre managers then approached their teachers regarding who would be able to participate in this research. The main focus was on the teacher and their beliefs and practices regarding assessing children's learning through play and development.

Using Google for contact information, I selected a variety of early childhood education centres and Kindergartens from across Wellington region and invited them to join the study via email. After several weeks, I managed to recruit three early childhood education centres willing to participate. However, before I was able to begin the data 
collection process, one of the participants withdrew from the research, as she had decided to resign from her place of employment. From here, I made phone contact with one of the potential participants that I had emailed earlier, and they agreed to take part in this study.

The three teacher participants in my study were employed by private early learning centres around Wellington. The head teachers were approached to suggest teachers they thought would be suitable to participate in the study. The head teacher/centre manager suggested teachers, who were willing to take part, and provided me with their email contact details, via information and consent forms designed for the centre/organisation. I spoke to the teachers who agreed to participate regarding the nature of my research. To ensure they were fully informed, I then sent out an information sheet to each teacher participant, explaining the focus of the study, along with a consent form. It was explained to the teacher participants that their identity, and that of their place of employment, would remain confidential, and that the findings of the study would not negatively impact them professionally.

\section{Methods of Data Collection}

The three case studies in this research provided the data for analysis and findings. The aim of this research was to discover the teachers' beliefs and practices in their natural settings (Merriam, 2001). Several methods of data collections were used to enable data triangulation (Creswell, 2007) which enhances the credibility of the data analysis (Lincoln \& Guba, 1985). Triangulation is an approach to test validity though merging of information from various sources and help identify (in)consistencies in emergent themes that enables the reduction of systematic bias (Patton, 2002). Therefore, triangulation provides opportunities to reinforce the credibility and reliability of this research (Merriam, 2001). 
The sources of data drawn on in my research were two sets of semi-structured interviews with teacher participants, pre- and post-observation interviews, one-hour observations every day for three consecutive days of teachers' practices, assessment and pedagogical documentation and field notes. These different data sources enabled me to make comparisons within and between cases.

\section{Semi-structured interviews}

The primary method of investigating teacher's beliefs on children's learning through play was via semi-structured interviews. Denzin and Lincoln (2008) state that interviews provide studies with individual "lived experiences" which are meaningful and provide in-depth understanding during specific interactions with participants (p. 47) and are an important source of information.

The interviews provided me with opportunities to gain valuable information regarding the teacher participants' real-life experience and to answer my research question about teachers' beliefs about learning through play and the impact of their assessment approach to play, from each participant's own perspective and in their own words (Huberman \& Miles, 2002). One semi-structured, in-depth interview about beliefs and practices was conducted with each of the three teacher participants. A follow-up interview was conducted with each participant at the conclusion of the third observation. The interview schedule was used as a guide and is shown in Appendix B.

The interviews were conducted at the teacher's place of work, as per their request. The interviews ranged in time from 15 minutes to 60 minutes, depending on how much the participants wished to elaborate on the topic. I was conscious of my ethical responsibilities taking precedence over any advantage my interviews might offer for this 
study. Therefore, I informed the teachers that they had the freedom to choose at any time if they wanted to end the interviews or if they did not wish to answer any of the interview questions. They were informed that the transcribed interviews would be referred to them for factual accuracy checking before I began my analysis.

Following the interviews, as requested by the teacher participants, I emailed them for further information. This was due to the teachers informing me that they could not give extensive answers during interviews as they needed time to think. All the follow up emails provided valuable and useful information as the teachers were busy and unable to meet for further interview sessions. These emails were an additional source of data to expound the teachers' perspectives on learning through play and assessment.

\section{Observations of teaching practice}

Merriam (2009) suggests that "observational data represent a first-hand encounter with the phenomenon of interest rather than a second-hand account of the world obtained in an interview" (p. 117). Observations were required as interviews do not always accurately reflect an individual's interpretation of the world and can be influenced by various factors, such as why they are being interviewed or their personal reasons on how much information they would like to share (Seidman, 2006; 2013). Observations provided "additional information" (Yin, 2003, p.93) and understandings of "teachers' outwards behaviours" that were visible within the context in which they transpired (Borich, 1999, p.99).

In my observations I sought to capture the teachers' behaviours, actions, gestures and oral interactions which were used to triangulate with other methods of data collections such the semi-structured interviews, field notes and document analysis (Merriam, 2009). 
My observations captured interactions between the teacher participants and the children in their care, as they participated in a variety of activities and routines that took place at each centre (see Appendix $\mathrm{C}$ for observation schedule)

I undertook the role of a non-participant observer in the centres and observed three sessions in each centre for approximately 60 minutes each time. As a non-participating observer, I endeavored to adopt a distant role, staying separate from the activities observed without participating or interacting with the participating teachers or the children. This enabled me to remain an outsider but to obtain an insider view of the phenomenon.

Document analysis

Documentation in the form of planning and learning stories was a further data source and played a "subsidiary or complementary role" to interviews and observation for this research (Denzin \& Lincoln, 2008, p. 354). This data helped supplement the data collection method of the observations and interviews carried out in this research. The documents were not collected to respond to the research questions but to corroborate other data. They were also used to triangulate the data during the analysis such as the interviews and observations (Merriam, 1998).

All three teacher participants provided me with their planning documentation and learning stories they had written to document children's learning that showed their assessment practice. While I did not collect or make copies of any of these documents as teachers did not want to share children's confidential assessment information, I was given permission by the teachers to take notes of important points for data analysis. My notes about their planning and learning stories were catalogued alphabetically, with the 
source, date, and place, to enable me to retrieve these documents when I needed them (Miles \& Huberman, 1994).

\section{Field notes}

Field notes were used to illustrate the location and atmosphere of the play activities where the observations were being carried out which included my personal reflections. The field notes were taken during every observation to record the learning atmosphere or "climate" or the "physical and emotional environment" of the play (Borich, 1999, p.14). I sat at the back of the room and my notes included quotes or any actions by the teachers that I felt were significant. This included my thoughts that I felt would be significant for the research, a self-reflection of my personal observation to be included as a form of triangulation of data to for this research (Berg, 2007). In addition, I recorded details and descriptions of the classroom as soon as possible after the interviews. The field notes recorded during this research allowed me to become familiar with each centre's setting. I was able to note how the centre's environment was set out and that assisted the observation of the play-based lessons.

\section{Theoretical Framework: Constructivist theories of Development}

Theoretical framework relies on a formal theory that is "constructed by using established, coherent explanation of certain phenomena and relationships" (Eisenhart, 1991, p. 2005). Therefore, a theoretical framework consists of theories that underline this research plan and the concepts (Osanloo \& Grant, 2016), as well decisions made in the research process (Mertens \& Hesse-Biber, 2013). Sarter (2006) addresses the "limited usefulness of findings and conclusions" when research is not supported by a theoretical framework (p. 494). The theoretical framework enabled me to analyse my findings using 
the constructivist theories of learning through play that explore the relationship between two dominant theoretical orientations within the constructivist theories of play of Lev Vygotsky (1978) and Jean Piaget (1973) and the extent to which they influenced the teachers' beliefs and practice. Figure 3.1 shows the theoretical framework used for analysis of the data for this research.

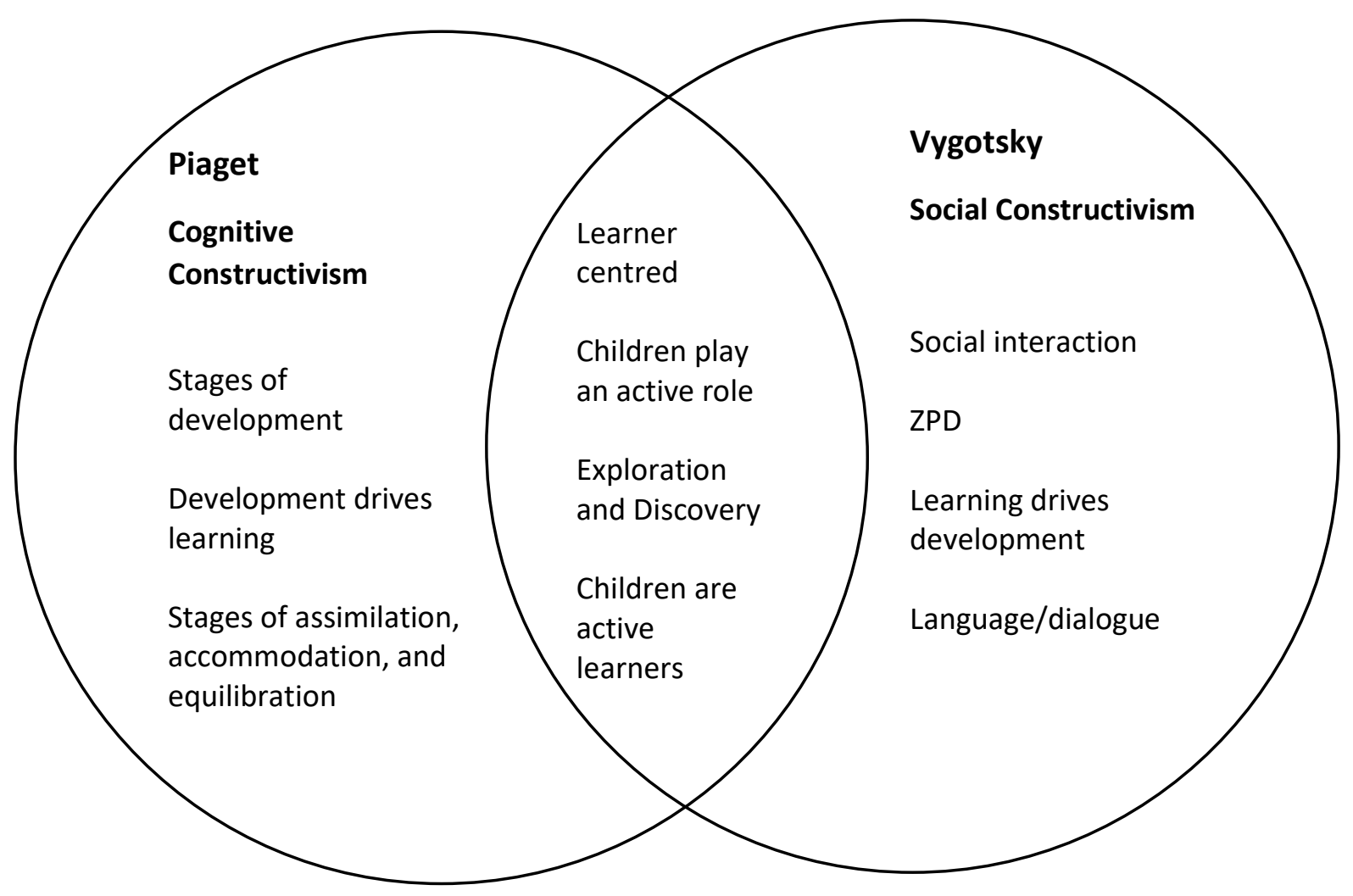

Figure 3.1: Theoretical framework: Constructivist theories of learning through play

Lev Vygotsky (1978) stressed the significance of social interaction in the development of children's cognition. Children's surroundings such as family, community, and the world around them, play a fundamental role in the process of children making meaning of the world. Vygotsky's (1978) sociocultural approach to the children's cognitive development argues that social learning comes before development. This counters Jean Piaget's (1973) concept that children's development leads their learning. Although the 
theories differ, both theorists believe that young children should be actively involved in their own learnings, such as discoveries and the development of understanding new concepts and schema (Piaget, 1973; Vygotsky, 1978).

Vygotsky's (1967) social cultural theory suggests that the children's world is shaped by their families, communities, education, and culture. The environment and context children experience influence their perception and knowledge of the world around them, as well as learning from peers. Children learn new concepts and language proficiency when they interact with others (Bodrova, 2003; Vygotsky, 1967). In addition, children's learning occurs through interaction with their teachers, through modelling or providing instructions to them, for example, a cooperative or collaborative dialogue. This then leads to the internalisation of the information to regulate their behaviours that assist in the children's cognitive development of Zone of Proximal Development (ZPD) (Vygotsky,1978). In addition, Vygotsky (1978) stressed the importance of interactions with peers as another way of developing their knowledge and skills and suggests the use of scaffolding such as arranging tasks so children can work towards their learning and development.

Piaget's (1973) cognitive theory focuses on children and their development instead of their learning. This theory does not address learning or behaviours. Within this theory, cognitive development was restructuring of mental processes because of children's environmental experiences. This theory stressed that children construct their own understanding of their surroundings through new experiences and adding to their current knowledge. The basic components to this theory are schemas and adaptation to enable transitions (equilibrium, assimilation, and accommodation). Schemas are building blocks of intelligent behaviour, so children can form mental representations of the world (Piaget, 1955). As a result, children's development refers to the increase in the complexity of schemata that a child has learned, a set of linked mental representations of the child's world. 
Piaget (1955) viewed intellectual growth as a process of adaptation of the child's surrounding through assimilation (using existing schema to deal with new situations), accommodation (when pre-exiting knowledge does not work and needs to be altered to deal with new situations) and equilibration (cognitive development does not grow at a fixed rate but though leaps and bounds). Equilibration is the key that drives the learning process and suggests a child will seek to master new challenges through accommodation when new information does not fit into the child's pre-existing schemas (assimilation). Discovery learning, a concept put forward by Piaget (1973) suggests that children learn by doing and exploring, central to the transformation of early childhood curriculum of learning through play. The theory advances the themes that children's play should be flexible and the use of their surrounding for learning through discovery is significant to the assessment of their progress (Piaget, 1951). Children's readiness should be considered when new concepts are taught and should be appropriate to their cognitive development. Therefore, assimilation and accommodation of this cognitive development requires an active learner as problem-solving is to be discovered by the child and not taught.

This interaction within an environment creates learning (Piaget, 1973) Additionally, Piaget (1973) suggests children understand concepts better when they are engaged in play, as it is a natural way for children to express themselves and their ideas. This often is as a result of observing and mirroring situations around them. Piaget's (1973) constructivism worldview suggests initiating learning through play by emphasis on stimulating children's interest, experimentation, and discovery methods. Within the Constructivist theory of learning through play framework, the argument is that children have their own view of the world and although it differs from their teacher's view, their views are coherent, robust, and meaningful (Piaget, 1973; Vygotsky, 1978). Children have their own logic that often fits with their current settings or world and should not be considered as incomplete adult views. According to Piaget (1973), knowledge is not information that is delivered, programmed, memorised, recovered, and applied but 
involves experience that is attained through interaction with the world. Therefore, conceptual changes and learning have their own meaning among children. For children, the world is gradually shaped and transformed through their experiences.

However, there are four commonalities between Piaget (1973) and Vygotsky (1978): play should be learner centred, children play an active role in learning, children learn through exploration and discovery; and children are active learners. These four similarities in the theories indicate that play is learner-centred and for it to be effective teachers take into consideration the learners' interest. The teacher's role during the learning through play is to provide an environment that encourages interaction and facilitates the play activities (Vygotsky, 1978; Piaget, 1973). In addition, within the constructivist theory, teachers create opportunities for learning and engage with learners in a socially organised environment through scaffolding (Piaget, 1973).

\section{Limitation of the Theoretical Framework}

There are several limitations in using the Constructivist theories of learning through play framework (Piaget, 1973; Vygotsky,1978). One limitation is that the framework did not identify what action to take if a child displays little or no motivation to learn. The theories assume that all children are active learners, but not all children have the motivation and/or attentions span to continue to develop their skills or assimilate new ideas. Vygotsky (1978) did address this to some degree through scaffolding, however it remains a weakness. In addition, neither theory accounts for the knowledge gained through children's exposure to technology. Many children may have changed their learning styles from kinaesthetic to visual as a result. The other limitation of the framework

is that both theories failed to distinguish between competence and performance in assessing the competence of a child. 


\section{Method of Data Analysis}

The data gathered was analysed through the interpretive qualitative lenses (Bogdan \& Biklen, 2007). The data analysis was a systematic process of grouping the data into significant and manageable units in order to gain a thorough interpretation (Cohen et al., 2007). The data analysis involved organising and interpreting data through the teacher's definition and context, key significant relationship, patterns, and themes were identified (Cohen et al., 2007). This systematic process was inductive, interactive and a recursive process (Bryman, 2008). An inductive process involves condensing the raw data into brief summaries; establishing links between the research objectives; and developing a framework of the underlying structures, experiences or processes that are evident in the raw data (Bryman, 2008). As I was the researcher and the instrument in the analysis process, in the first stage of the analysis I developed the categories for comparisons and contrasting the data based on the theoretical framework and research questions in relation to the literature review (Creswell, 2009).

The data analysis conducted within the interpretive paradigm was focused on me as the researcher making sense of what was said by the participant teachers and looking for patterns (Patton, 2002; Stake, 2006; 2010). When analysing multiple cases, it is important to present a comprehensive description of each case, and the themes within each case, supported by thematic cross-case analysis (Creswell, 2007). I provided detailed descriptions of each participant teacher's beliefs about play. I recorded and transcribed the full interviews. I read each transcript and the set of notes to highlight significant issues and experiences. Then, I analysed the transcripts and notes and developed them into coherent and manageable summary for each case that was structured according to the theoretical framework, in order to enable my subsequent cross-case analysis. I analysed the cross-case comparisons to identify what was common 
and what was specific to individual teachers. This enabled me to obtain a unified description across the three cases; to establish categories and themes; and to build a substantive theory that covered the framework for the multiple cases (Stake, 2010). Finally, I compared the findings of the cases with those in the literature reviews.

Data analysis was an inductive process as I looked for themes and categories and deductive as the play and learning strategies from the literature and constructivist theories of development as a theoretical framework was used to analyse the data (Patton, 2002). I sought to identify key connections, themes, and categories (Cohen et al., 2007). This process enabled me to capture the uniqueness of each case that was important in this research as well as the phenomenon of learning through play for this research study (Stake, 2006; 2010).

My aim in the cross-case analysis was to compare and contrast all three cases of the participant teacher's beliefs and learning through play practices, with attention to the effects of their beliefs on their practices. My cross-case analysis highlighted the interconnected themes arising from the cases and helped shape and answer my two research questions. Firstly:

- What beliefs do early childhood teachers hold about the role of play in children's learning?

Secondly, the cross-case analysis of my observations, document analysis and field notes enabled me to answer the second research question:

- What role do teachers' beliefs on play have in the assessment of children's learning? 
Figure 3.2 on the following page provides a diagrammatic representation of the procedures and methods of data collection utilised in this multiple-case study research. The exploration within and between the three cases for commonality and variations is clearly highlighted.

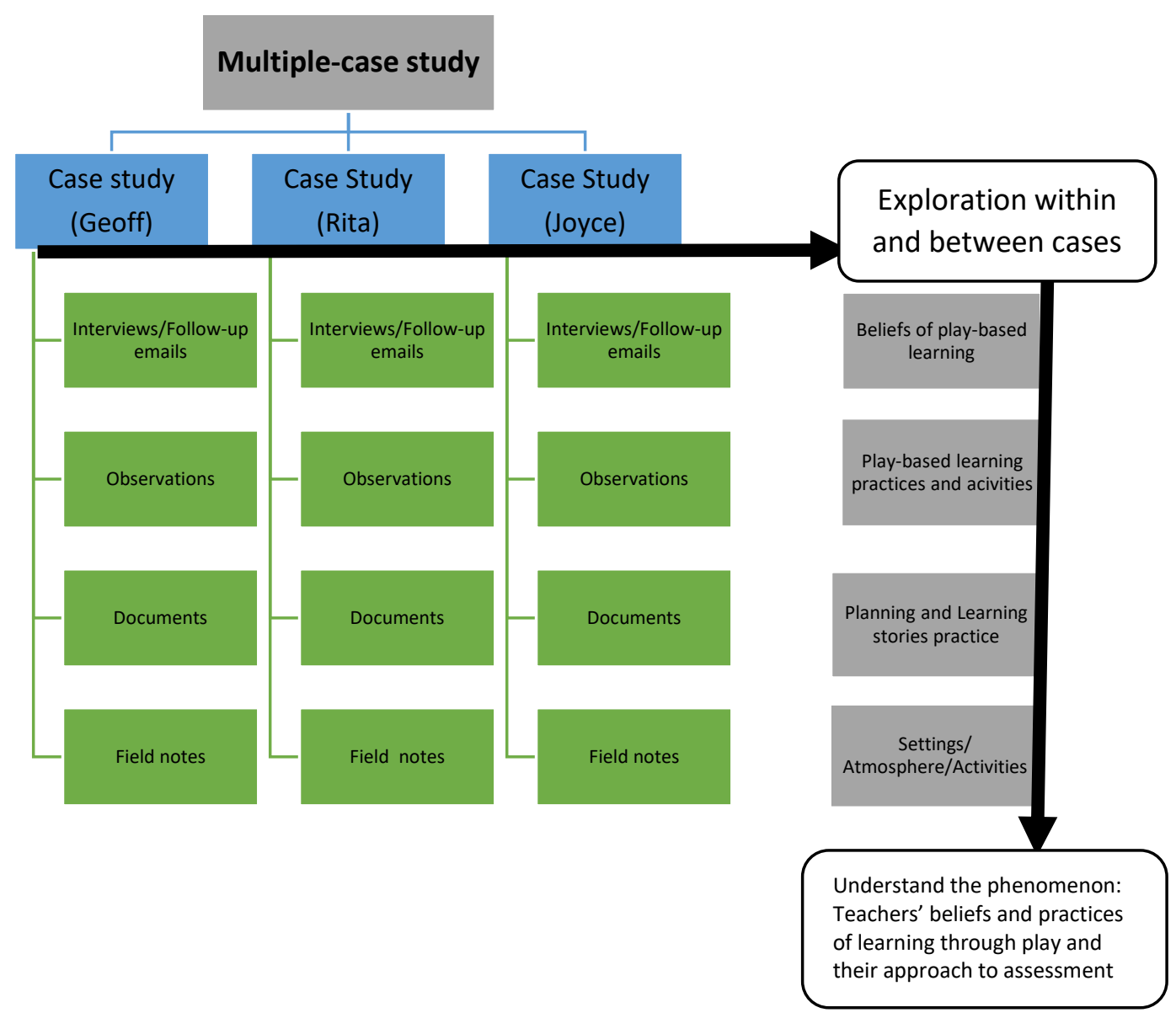

Figure 3.2: Multiple-case study processes and methods of data collection

\section{Coding and categorising}

The interviews for this thesis were all transcribed as qualitative research requires words as the unit of analysis (Denscombe, 2003). I went through the data looking for 
'words, patterns of behaviour, subjects' way of thinking and events which is repeat and stand out" (Bogdan \& Biklen, 2007, p.173). The observation enabled me to identify repetition or variations and therefore I used the coding process of integrating and improving the categories that represented the themes that arose for this study (Strauss \& Corbin, 1994). I utilised the theoretical framework as an inductive instrument to help group the categories to form a descriptive whole picture. The analysis involved creating a coding system in which the transcripts were scrutinised for regularities and peer debriefing with my academic supervisor helped the clarification process.

\section{Trustworthiness of the Research}

Trustworthiness can be seen as a set standard that honours each participant of a research ethically (Rosman \& Rallis, 2012). I maintained trustworthiness through four aspects: credibility, transferability, dependability, and confirmability (Guba \& Lincoln, 1985). In this research, the interviews and observations enabled me to capture sufficient representation of the context of the teacher's world, to ensure the accuracy of the data collected.

The extended, prolonged engagement and the multiple methods frames as endeavours to strengthen the credibility of the data, enabling the integration of conceptual relationships and theoretical position of each participant (O'Donoghue, 2007). Transferability requires the researcher to support the thick description of findings through in-depth analysis of interviews, observations, documents, and sampling to enable to possibility of the process to be employed to other contexts (Denzin \& Lincoln, 2011). These datasets generated through purposeful selection of participants to understand the phenomenon should be able to be replicated with participants in similar backgrounds. 
Dependability refers to the thoroughness of the research findings in relation to consistency across all cases such as an audit trail of all documentation, chain of activities and evidence form the time of the data collection to the analysis of the research findings (Merriam, 2001). Following advice, I logged all activities prior, during and after data collection up to the data analysis, which included memos, logs and field notes. This created an audit trail throughout the research (Denzin \& Lincoln, 2011). My academic supervisor assisted me with guidance on the depth of data analysis required.

Confirmability is the degree to which the interpretation of this study was "grounded by events" rather than my own personal interpretation and beliefs about learning through play (Guba \& Lincoln, 1985, p. 324). My research process is clearly highlighted in this thesis from data collection to the analysis. The issue of confirmability was addressed by detailed descriptions of my research process and data collection methods and linking them to the data analysis for my findings. Extensive appendices have been provided as supporting evidence for this study. Efforts to address researcher bias included comprehensive descriptions of participant teacher selections and justifications of the selection and processes (Lincoln \& Guba, 1985) and discussions with my supervisor.

\section{Researcher Bias}

As the researcher and the person who made the selection of the data for this study, I acknowledge that I was a significant research tool. My education, background, values, identity, and beliefs will have substantial "bearing on the nature of the data collected and the interpretation of the data" (Denscombe, 2003, p. 234). I attempted to minimise bias by maintaining a strict observer position and refrained from making personal and evaluative statements or comments during the interview sessions. I did not interact with children prior or during the observations. 


\section{Ethical Considerations}

I observed and adhered to Victoria University of Wellington's ethical principles and guidelines on human subjects by following processes such as minimising risk by assuring confidentiality of the participants' identities and gaining informed consent (see Appendix A). This was recognised by Johnson and Christensen (2008), as one of the most fundamental ethical issues to consider when carrying out research with human involvement. Significant care was taken not to reveal the teachers' names, ages, or ethnicity. Ethic of care was a fundamental measure taken to assure participants that their confidentiality and anonymity was an important factor in my research. Each ECE centre, teacher participant and child were given a pseudonym to ensure that their identity was confidential to the researcher.

The aim was to minimize potential risks to teacher participants and the children in their care. I took on the role of a non-participant observer to minimise disruption to the running of the ECE centre and the children's play and learning. Information sheets were sent to the Head Teacher (see Appendix A1) of each early learning centre prior to the research being conducted. Once the Head Teacher agreed to participate (see Appendix A2), a teacher participant could be invited to participate in the study, I emailed an information sheet and consent form through to the teacher participant (see Appendix A3, A4). Once the teacher agreed to participate, consent forms for parents were sent home (See Appendix A5, A6). These forms were then collected prior to observations being conducted. Informed consent was gained from children prior to observations taking place (see Appendix A7). 


\section{CHAPTER FOUR:}

\section{CASE STUDY ONE: GEOFF}

The purpose of this research is to investigate teachers' learning through play beliefs and practice and their approach to assessment. Creating a case study profile from interviews through the words of participant teachers supports the interpretation of context, provides clarity into teachers' intentions, and gives insight into the process that is a significant part of a qualitative analysis (Siedman, 2006). The following three chapters provide a detailed description of each case study participant teacher in their own context. These descriptions are based on interviews, observations, documents, field note analysis and centre websites to provide the background of their centres. Based on observations, there is a description of their learning through play beliefs and practices and their approach to assessment. This is followed by a description of themes that emerged from analysis of their play-centred teaching and learning practices.

In chapters Four, Five and Six, each teacher's profile is presented in the following order: an introduction to the teacher's background, their professional learning and development, the early education centre they work in and their teaching practice and assessment practices. Experience and qualifications prior to working as a teacher are also included. Chapters Four, Five, and Six provide an in-depth and rich description of the participant teachers' learning through play beliefs and assessment approach.

Introduction to Geoff (pseudonym) 
Background, education, and teaching experience

At the time of the research, Geoff had been teaching for four years in the ECE Centre A after graduating with a Bachelor of Teaching (ECE) qualification in 2015. He had 22 years of teaching experience which included an assistant teacher role at a Wellington primary school before becoming a Level 1-4 teacher at a Montessori primary school and currently a Room Leader at Centre A.

Professional learning and development

Geoff stated that his "professional learning and development has occurred within the centres he has worked at" (GI). Most of his "learning about assessments has been through mentoring by senior teachers or centre managers" (GI). Some has been through "observations of the children and monthly planning sessions and discussions" with the teaching team at Centre $\mathrm{A}(\mathrm{Gl})$.

Geoff's Early Education Centre (Centre A)

ECE Centre $A$ is an all-day education care for children aged six months to five years (Gl). It has three separate rooms and is licensed for 106 children (GI). Centre A has a teaching team of 16 teachers who are all fully registered and qualified in ECE (GI). Centre A's mission statement is to "prepare children for life by empowering them to grow as individuals and develop a love of life and learning" (GF). Room leaders at Centre A are responsible for curriculum development at the centre (GI). 
A bicultural curriculum has been developed to identify, strengthen meaningful Te Reo Māori and to provide visible representation of Te Reo Māori within the learning environment and documentation at Centre $A(G W)$. Teachers are described as committed to establishing connections with each child's culture, language, and identity. Centre $A$ is well-resourced to encourage exploration and challenges (GO). Teachers are wellsupported in the growth of their teaching practice and development to improve outcomes for children (GI). Professional learning opportunities and ongoing collegial discussions are key to reaching Centre A's goals $(G)$.

\section{Centre A's assessment practice}

Centre A uses the online portfolio system Educa to document children's learning (Gdoc). Children's 'learning goals are established using parents' aspirations, with guidance from teachers" (GI). Children have "individual planning charts" displayed on the wall of the main room (GF). Each plan is an A4 page with the child's photograph on it (GF). Teachers add notes of interests they have observed the child engaging in (Gl). Other notes added are around how well the child settled into the day, new accomplishments for example, climbing skills, and other children they may have played with (GO). Learning stories are written personally to the child and photographs are used extensively (Gdoc).

Geoff's Beliefs about Learning through Play

Geoff defined play as children's "interaction with the world around them" and "should be the forefront of their day" (GI). He believed that in ECE play should be the forefront of all planning and "incorporated into different aspects of a child's day" as that is how a child learns about "their world" (GI). He emphasised that there was a strong 
"relationship" between play and learning (GI). He stressed that during play children develop their "social-emotional skills" which is significant to the foundation of their "social competence" as they grow (GI). These social competency skills help them "deal with their surroundings and people through interactions" within their world (GI).

Geoff believed that during play it was either the "child" or the "teacher guiding the interaction and the direction of the play" $(\mathrm{Gl})$. He elaborated that there were often "warranted times" for a "teacher-led play" especially "depending on an age group or children's ability" (GI). However, he stressed that play should be "guided by the child" while the teacher takes on an "observer" role (GI). Geoff emphasised that the teacher's role is to "engage with the child" and bring elements of play into every aspect of their "daily routines" (GI). Geoff believed it was important for the teacher to "connect" with the children and "support" their learning during play-based activities by physically "going down" to the children's "level" (GI). For example, if they were on the floor, the teacher then sits on the floor with them to be able to see them "face-to-face" (GI). He indicated this was to support and understand them in "their playing field" by the teacher "role modelling their view of the entity" (GI).

Geoff stressed that the "use of language" during play-based interaction was an important aspect of "supporting children during their learning" (GI). He supported children's learning by using both "English and Te Reo Māori" as he strongly believed in supporting the "language development" of the children during play ( $\mathrm{Gl}$ ). He believed that "learning an additional language" supports both the "cognitive development" and "thought process" of children ( $\mathrm{Gl}$ ). This enables them to "explore language" in a "safe way" by understanding how to use and "respect" each other through various language interactions (GI). He believed this helps children in "learning different styles" of speaking and using "words" multiple and different ways (GI). 
He added that play should be incorporated and continued as a "learning tool in a child's life until their intermediate learning years" as it would help them in their "social skills" (GI). This was because Geoff believed that through play children are able to "strengthen" their "kinetic, visual, hearing and taste sensory devices" (GI). This was the reason play was an important aspect at the centre. He observed learning through "repetitions of the child's behaviour" (GI).

Geoff believed "free play" was key to learning and should be the "focus" when organising play (GI). However, instilling "fun" and "enjoyment' into play activities should be the focus, and this was one of Geoff's goals (GI). He also indicated it was "important to "learn alongside" the children and his "own love of learning" (GI).

Geoff's understanding of assessing learning through play

Geoff's belief regarding assessment is that it is a "teaching process" where he is "assessing himself" and his "teaching and learning strategies" (GI). He stressed that assessment itself should not be the "utmost important" aspect but rather, the learning process of the child (GI). To "enhance" the teacher's assessment practices, Geoff said that Centre A was going "through an internal evaluation" process of creating goals for children as professional learning and development $(\mathrm{Gl})$. This included "monthly centre planning" strategies as well as setting "individual children's goals" to be discussed with their whānau (GI). The monthly planning is mainly to support Centre A teachers' use of the "Te Whāriki curriculum" and to set out goals to be assessed (GI). This then becomes "guidance" for the teachers' teaching approaches and assessments (GI). Geoff believed "a lot of the learning stories" had been "exploration" by teachers of their assessment practices $(\mathrm{Gl})$. There were also weekly planning sessions to discuss children's progress and learning stories to create play activities to help individual children achieve their goals. 
Geoff's understanding of assessing play is "associated with each child's learning stories" (GI). Geoff believed that there were "two important aspects" when seeking to enhance children's learning and that was to "work alongside parents to create goals" for the children and the other "short-term and achievable" goals for each child based on teacher's observations ( $\mathrm{Gl}$ ). Teachers' "observations are a form of assessing" children's achievement of these goals. Learning through play captured in "learning stories help[s] document and assess" whether children are achieving these goals ( $\mathrm{Gl}$ ). Geoff believed that "ticking off those goals created in partnership with the whānau" through observations validates that the children are "learning through play" (GI).

Geoff viewed observations as the main "form of assessing" children's learning through play. In addition, the "teacher's perspective during the observations paints a picture of the type of learning that is academically" seen in classrooms (GI). The children's learning stories tell of the child's "achievement of the goals set for them". Geoff writes and "personalises" the learning stories "for the children" by writing the achievements using simple language (GI). For example, "Charlie, it was really nice to see you...". He believed this enabled him to "engage" the assessment and achievement directly to the children and help them understand that they had achieved something. It also helped him know that "learning had happened" (GI).

Geoff identified a number of key elements he looks for when assessing through observations. These are "repetitions, engagement, individual play, learning from peers, or looking for teachers' feedback" (GI). It also includes the child's social behaviour with teachers and their peers. He believed that placing himself with the children during the observations helps enhance and develop the children's learning and improves their understanding of that learning. It is also "respecting they are still learning and still have to know what is happening" (GI). It helps put "ownership onto them" and allows him to observe the "transition and the acquisition of language" coming through (GI). For Geoff, 
the most important factor during play is 'fun and enjoyment' and not achievement as "children's development is an individual process" (GI).

\section{Geoff's planning}

Geoff planning document indicated for week observed:

"Set up the learning environment to encourage sensory exploration in a safe, calm, and independent manner. Provide opportunities for children to socially interact with their Kaiako and peers in order to establish trusting attachment relationships. Extend children's language by providing different words and phrases in both English and Te Reo" (Gdoc).

\section{Observation Day 1}

Geoff had prepared his learning through play activity for under Twos children near the dramatic play area and had put Perspex building blocks as preparation for the children's play on Observation Day 1. He interacted with each child and their pretend play activities before encouraging them to join him in building the Perspex building blocks.

Child A was pretend drinking from a toy milk bottle and Geoff wanted to encourage child A to share.

Geoff: Would [Child B] like some milk (to Child A)?

Child A: (Looks at Child $B$ and passes the bottle to Child $B$ ).

Child B: (Mimics Child A's action and starts drinking from the bottle).

Geoff: Yummy milk (while rubbing his stomach).

Child A: (Picks up a plastic builder's helmet and gives it to Geoff).

Geoff: Thank you for the helmet. (and repeats the word) Helmet.

Child A: (Picks up a square Perspex block and offers it to Geoff).

Geoff: Shall we do some building? (Moves closer to the building block area and starts stacking the blocks one top of another). 
Child A and B copy Geoff's actions and start stacking blocks. Child C sees the activity and picks up blocks and hands them to Geoff. Geoff thanks Child C.

Geoff: Shall we build something? (in an animated voice).

All three children start stacking the blocks until they reach a certain height before it collapses. Child A picks up the toy helmet and puts it back on. Geoff then encourages the child to place it on Child C's head, but gently.

Geoff: Gentle, very good. Good gentle hands. Good sharing.

The three children are then joined by Child D, E and F on the mat and they start playing together with the Perspex blocks. Geoff helps the children build a tower and at the same time names the different shapes and colours of the blocks.

Geoff: What shape is this? It's a square (repeating the word till the children became focussed on the shape). Square. (Child $D$ examines one of the blocks, holding and scrutinising it).

Geoff: What can you see inside? This one has sparkles (continues to encourage exploration of the blocks while continuing to name the shapes in a gentle and playful tone).

Child $\mathrm{G}$ and $\mathrm{H}$, who had just woken up, approach Geoff in the building blocks area. Geoff asks Child $\mathrm{H}$ if she needs her warm top and where it is. Child $\mathrm{F}$ picks up the top and passes it to Geoff.

Geoff: Thank you for giving it (to Child F). Now [Child H] won't get makariri (cold).

While all the children are playing with the building blocks Geoff gets the camera ready to document the interaction between the children. Geoff starts singing along to a CD playing "Incy wincy spider" and places a ball on the block and the children laugh. Child G, F and $\mathrm{H}$ go outside with another teacher. Geoff then picks up a toy, featuring dinosaurs that pop out of eggs when buttons are pushed. As he pushes one of the buttons, a dinosaur pops out from the egg. He demonstrates to the three remaining children who get excited and start playing with the object. Geoff encourages them by saying "Ka pai". The play activity concludes, and the children move to different activities. 


\section{Observation Day 2}

For Observation Day 2, Geoff had prepared a variety of play resources for the children. Geoff interacts with children individually while they are playing with different resources. Geoff observes Child F playing with a basket of small plastic animals that Geoff had placed near him.

Geoff: What is it? What are you holding? Have you got a cow? (He mimics the sound of a cow mooing and the child smiles). Can you find me a pig? (repeats the statement in Te Reo Mãori and continues playing the game with the two children).

Child $G$ and $A$ interact with some of the play resources nearby. Child A suddenly picks up a shaker toy and throws it. Geoff gently reminds the children:

Geoff: We throw balls, not toys (then demonstrates how to use the toy properly by shaking it before passing it back to Child $A$ who then mimics his actions). Can you shake it? Can you spin it? Good work. Ka pai (directed towards Child $A$ ).

Child C: (Picks up a duck toy and shows it to Geoff).

Geoff: Duck. It is a duck and the sound it makes is quack, quack (some children laugh and mimic the sound)

The children on the mat start taking out different animals and showing them to Geoff. $\mathrm{He}$ encourages them to try saying the names of the animals and make the sound. Suddenly Child A starts singing the song 'Paki paki' and Geoff (smiling) praises the child's singing and performs the actions to the song. The children laugh as they try to mimic the actions with Geoff singing the song. Geoff took photos of the children's activities.

Geoff then takes a small bean bag and places it on his head and shows the children how to balance the bean bag on their head. Child C, F and D watch and he places one small bean bag on each of their heads. Geoff encourages them to keep trying even when it falls off. Child $A, B$ and $E$ take an interest the other children are having and approach Geoff wanting to try it too. 
Geoff: How long can you keep it on your head for? Let us try now. What will happen if you look up? (as the children try their bean bags fall off). Let's see what happens when you look down? (as the children try bean bags fall off). Let's try jumping and see if it falls off (the children clap, and start trying it and laugh when it falls off). Hold your upoko (head) still (as he places another bean bag on their head). Shall we try three now? (children continue to try balancing different numbers of bean bags that Geoff places on their heads).

As the children's interest wanes, Geoff starts singing "Head, shoulders, knees and toes" and performs the actions. The children join in by mimicking Geoff's actions. He encourages the children often saying "Ka pai" and "you did really well". The children then go for their afternoon tea.

\section{Observation Day 3}

Geoff facilitated an outside play session on Observation Day 3. Geoff indicated he wanted to enhance the children's understanding of spatial awareness while digging in the sand pit (GI). He also indicated he wanted to observe children's understanding and interactions with their surroundings and play resources $(G \mathrm{l})$. He recorded the outside interaction for his learning stories. He led Child $A, C, F$ and $H$ to the sand pit and had a spade ready for them. Child $A$ decides to ride a bike and $C$ hild $C$ and $F$ move to the climbing equipment. Geoff stays with Child $\mathrm{H}$ at the sandpit as Child $\mathrm{H}$ continues to dig using the spade.

Geoff: What have you found? (Child $H$ does not answer but continues to dig). Child $\mathrm{F}$ and $\mathrm{C}$ walk towards the sandpit and find small spades to dig with. Geoff takes a bucket. Who wants to help me fill the bucket with sand? (Child C, F and $\mathrm{H}$ move closer to Geoff to help him). Can we work together? Can we keep the sand in the sand pit? (Geoff gently reminds Child $\mathrm{H}$ and the child modifies the digging and filling up the pail without letting sand getting outside the pit). Ka pai. Good work. 
Geoff notices Child A and D standing around and not interacting or joining the activities. Geoff then moves to the water trough close to the children, beginning to drum on its lid. There is a small amount of sand on the trough lid and it moves as Geoff drums.

Geoff: Look at the sand move when I drum (to Child $A$ and $D$ who were standing there observing the children play in the sand pit. Geoff begins singing). Old MacDonald has a farm, EIEIO. What lives on the farm? (Geoff pauses). May be chicken? (he suggests).

The other children gather around him and start moving to the music. Geoff encourages the other children to drum on the water trough lid. Child A, D and F begin to bang on the lid with their hands and laugh. Geoff begins to tidy up the outside area and suggests that the children get brooms to help with the cleaning before afternoon tea.

\section{Geoff's learning story documentation}

Geoff's observations of the children's play activities were documented for the children's learning stories. His documentation of children's learning stated:

"The children have been exploring the different materials set up for them in the learning environment, exploring the blocks and plastic animals one their own and with other children. Teachers continue to work closely with the children to establish close trusting relationships. [Child D] is coming out of his shell and is developing a closer relationship with [Teacher $C$ ]. Teachers are continuing to use different words and short phrases with the children." (Gdoc). 
The relationship between Geoff's beliefs and practices

Geoff's espoused learning through play beliefs and assessment practices reflect understanding gained from his teaching experiences, Centre A's professional learning, and the Te Whāriki curriculum (GI). Geoff's beliefs and practices appeared to be aligned within the social constructivism side of the theoretical framework in that he strongly advocates social interaction, language, interest in children's development and children being active learners (GI). However, aspects of his beliefs and practice, such as considering "children as active learners, interest in the children's development through exploration and discovery" (GI) lean towards the constructivist theories of learning through play (Piaget, 1973; Vygotsky, 1978).

There were some inconsistencies between Geoff's espoused beliefs on learning through play and his practices. Geoff reported that play was a child's "interaction with the world around them" (GI). However, at times during the observations, Geoff brought the children into a teacher-led play activity pre-planned by him or his team and away from their pretend play or social play activities they were involved in (GO). Geoff believed that play should "guided by the child" (GI), however, during observations he frequently initiated play activities, such as when he encouraged the children to balance bean bags on their heads on day two (GO). His belief that children "learn during play" (GI) was observed. Although he purposefully-framed the play, the children were active learners and had opportunities to explore the designated play area and discover for themselves all the materials he had placed for them, such as when one of the children explored the plastic play animals (GO).

His belief to "connect" with the children and "support" (GI) their learning by going down to their level was often observed when he sat down on the mat and interacted with 
individual children and facilitated their language development, such as when he encouraged the children to name the animals on day two (GO). This was consistent with Geoff's belief that the "use of language" was important for the "cognitive development" of a child (GI). Through his use of language, Geoff facilitated children's language development and understanding of the objects they used during play, for example when he pointed out the sand moving on the water trough as he drummed on day three (GO). This included extending and assisting (GF) children during the activity, ensuring progression of each child involved in the play.

Geoff indicated during the interview that play is important in developing "social competence" $(\mathrm{Gl})$ and this was observed in the way his play environments were organised to be socially interactive and to ensure children practiced the language and understood the meaning through repetition (GO). He organised activities that involved more than two children and often helped the interactions to be polite, instilling attitudes of sharing and respect among the children $(G O)$. His practice was consistent with his belief that language enabled the cognitive development as he "scaffolded and supported children" during their exploration and discovery of knowledge in the observed play. Geoff's reported beliefs and observed practices aligned with social constructivist theories. Geoff reported a learnercentred pedagogy where children were active participants during play activities. Geoff's reported beliefs emphasised language interaction between him and the children. Geoff stated he believed that children are "active learners" and play should be organised based on children's interest (GI). Geoff's role during the learning through play included organising a "socially interactive play environment" (GO). During all three observation sessions Geoff scaffolded and supported children's "exploration and discovery of knowledge" while playing Perspex blocks (GI, GO). He "directed and guided" the children during play and made the play sessions fun by including singing and dancing (GO). Geoff's beliefs and practice relationship placed him on the social constructivism side of the theoretical framework. The relationship between Geoff's beliefs and practice are shown in Figure 4.1. 


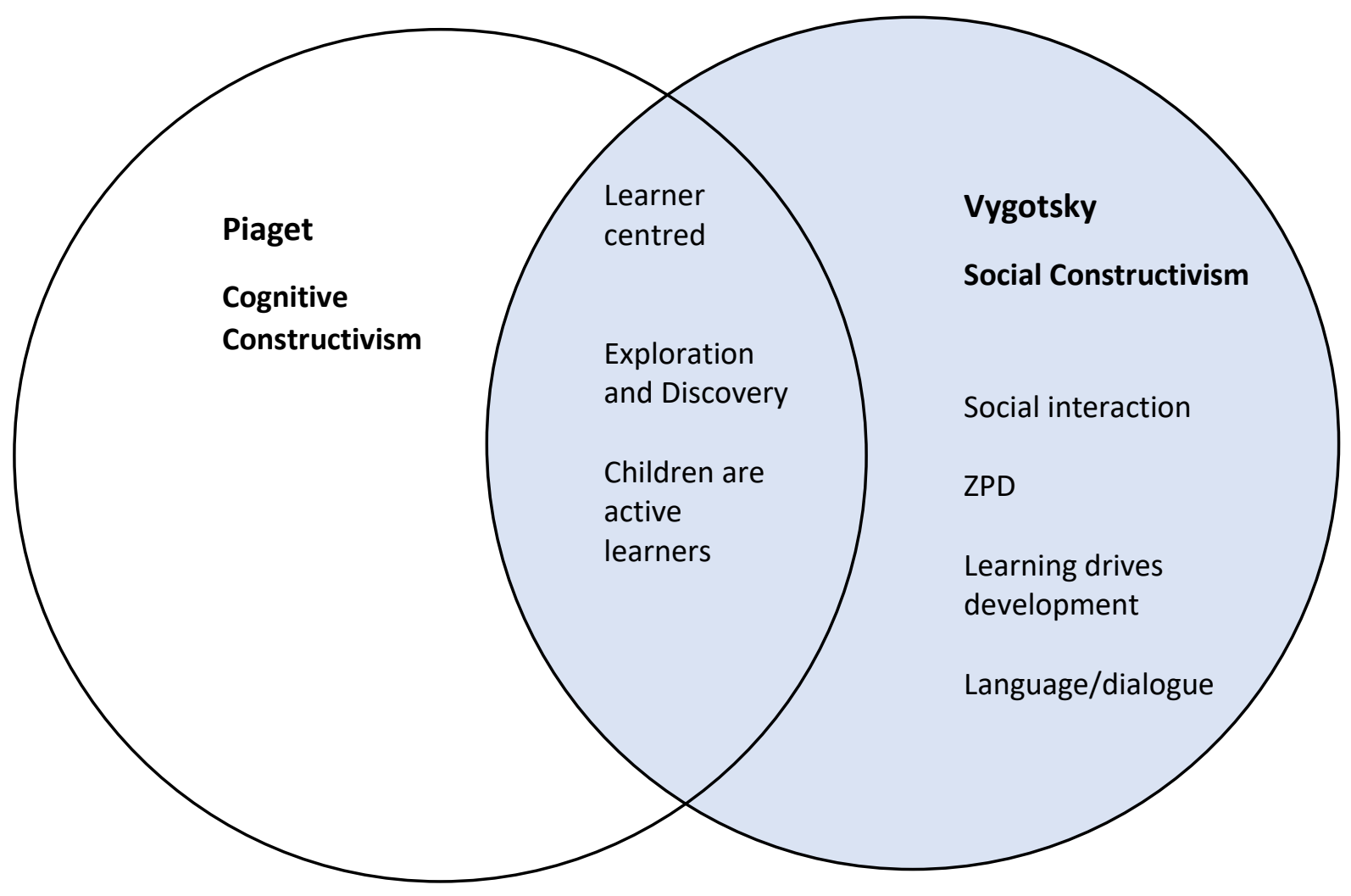

Figure 4.1: Geoff's reported beliefs and observed practice

\section{Themes}

As discussed in Chapter Three, information collected from teacher interviews, observations, field notes and documents provided data for analysis and helped identify three significant themes relating to Geoff's beliefs regarding learning through play and his approach to assessments. These were Geoff's purposefully framed, teacher directed play; enabling facilitative bilingual interactive play; and exploration of his own teaching practices as a result of his assessment practice. Using these concepts enabled Geoff to assess through observation (GI, Gdoc, GO). 
Purposefully framed and teacher directed play

One of the key learning through play findings was that Geoff had teacher- directed play activities purposefully framed to ensure his learning goals for children were met. One way that Geoff took an active role in the play activities was by providing a variety of "play resources" (GO). The play activities were pre-planned by Geoff as preparation for working towards the children's learning goals. Geoff provided the children with materials for their play activities every day that was observed. He frequently modelled using and interacting with play materials, with his actions often being mirrored by the children, such as when he and the children built with the blocks on day one (GO). He provided opportunities for the children to be more creative and explore using the materials and the children were often able to socially interact with their peers in open-ended play. For example, during observation on day 1 , when the children were able to choose the materials and interact with their peers as enabled the interaction.

Geoff "set up the learning environment" to encourage "sensory exploration" $(\mathrm{GI})$ in a safe, calm, and independent manner. Geoff prepared the Perspex blocks (observation day 1 ), plastic animals (observation day 2 ) and sand pit (observation day 3 ). He sought to enhance the children's understanding of shapes and colours, animals and the sounds they make and spatial awareness (GO). During the sand pit play, Geoff sought to develop children's awareness of the environment and adapted his play activity when he found not all the children were interested in the sand pit activity (GO).

His observations of the children enabled him to adapt his play activities to make it interesting for them and as inclusive as possible. Although he had pre-planned the play activities for each day, when he realised children were quiet or interested in something, he started singing or dancing to capture their attention. However, it was observed, that 
Geoff still finished his planned play activities in order to facilitate the children's learning (GO).

\section{Facilitative bilingual interactive play}

There were collaborations between Geoff and the children but often the interaction was facilitative and leading back to the planned play activity (GO). Geoff was behaving as an 'outsider' during the play activity on the first, second and third days to ensure the children were fully engaged during play (GO). He often prompted the children and communicated with the children directly during the play activities to ensure there was a flow in the planned activities. His facilitation through language enabled children to repeat the vocabulary he was trying to extend.

As he believed that children are "active learners and developing language skills is important" (GI) to their cognitive development, during his observations he often used Te Reo Māori with the children (GO). He praised them in Te Reo Māori and used it a lot during his object play sessions by teaching the children the bilingual terms for the objects they were holding (GO). His interaction with the children were facilitative in nature and he sought to guide them in their exploration and discovery of objects. Although at times the children did not respond to his questions due to their age, his observation of their body language and gestures enabled him to progress with the play activities knowing they were following what he was saying (GO). The children often mimicked his actions or language which enabled him to record that learning had taken place and progress with the play activities. 


\section{Assessment influences self-exploration of teaching practices}

Geoff believed his assessment of learning through play was feedback and "selfexploration of this own teaching practice" (GI). His planning, observations, interaction and documenting children for learning through play activities enabled him to "continually think of children and their development" during his assessment of the children (GI). For example, in his learning story he documented "[Child D] coming out of his shell" (Gdoc). His observation of Child $D$ enabled him to create a meaningful social interactive environment for children and to assess the child's engagement. This was observed and documented as the child was "developing a closer relationship with [Teacher C]" (Gdoc). He pre-planned play activities that provided opportunities for children to socially interact with their peers and establish "trusting relationships" (GI) and "learning stories help[s] document and assess" whether children are achieving these goals (GI). He believed this enabled him to "engage" the assessment and achievement directly to the children and know that "learning had happened" (GI). 


\section{CHAPTER FIVE:}

\section{CASE STUDY TWO: JOYCE}

Introduction to Joyce (pseudonym)

Background, education, and teaching experience

At the time of the research, Joyce had been teaching for five years in the ECE Centre B. Joyce graduated with a Bachelor of Education (Teaching) Early Childhood in 2013. She had eight years of teaching experience at the time of the research, which included a role as an untrained reliever prior to gaining her teaching qualification.

\section{Professional Learning and Development}

Joyce had completed papers on assessment and children's learning from a New Zealand University during while studying for her Bachelor of Education (JI). This she had done as her "own initiative to understand the concepts and improve her teaching and learning practices" $(\mathrm{JI})$. Joyce indicated that her "professional learning had been mostly through experience and from her practicums" (JI). She also stressed that she had developed her knowledge about play from "observing and learning about children" which has led her "to develop her own way of doing things" (JI). 
Joyce's Early Education Centre (Centre B)

ECE Centre $B$ is an all-day education and care facility licensed for 22 children. Centre $B$ has a teaching team of five full-time teachers who are fully registered and trained (JI). The centre manager delegates responsibility for day-to-day management. At the time of research, all children enrolled at the centre were over two years old and came from a range of cultural backgrounds, none identified as Māori. Centre B celebrates Te Tiriti o Waitangi and other cultures (JI, JW).

Centre B's philosophy is to encourage their tamariki to be inspired, courageous, free exploring and adventurous risk takers who feel a sense of stability in their surroundings and have the opportunity to take time to escape to a quiet, comfortable, safe area (JW). Centre B's visions are to 'provide quality education within a family environment and its mission is 'to inspire courageous investigators within a secure, nurturing learning community' (JW). Te reo me ngā tikanga Māori is woven into the curriculum (JW). Children enjoy self-initiated learning activities through creative and imaginary play as they explore the well-resourced environment (JW). Children are actively involved in learning and continuous play for a considerable period of time (JW). The teaching team work collaboratively through coaching and professional development (JI).

\section{Centre B's assessment practice}

The centre uses the online portfolio system StoryPark along with profile books that the children can access $(\mathrm{JI})$. There is a wall display of children's learning stories in the main room, which are framed with headings from Te Whāriki in Te reo Māori (JF). The stories in children's portfolios are printed out using the StoryPark templates (JF). Learning 
tags are attached to each story, linking them to Te Whāriki, for example, the story of Belonging (JO). Learning tags are like labels or keywords that can be attached to learning stories (JF). They generally relate to elements of the curriculum, outcomes, goals, dispositions, schemas, values, culture, interests, or subjects (Jdoc). The learning stories contain lots of photos in order to make them more "accessible to the children" (JI). On another wall is a display of the teachers collaborative planning, called the Thinking Mat $(\mathrm{JI}, \mathrm{JO})$. This is a project approach of Centre B where the teachers document the children's learning on different interests over several weeks $(\mathrm{JI})$. The "learning journey is mapped out to see how the interest evolves over the time period and which direction the children take it" $(\mathrm{JI})$. Teachers also "observe if any of the interests intersect at any point" (JI). The learning journey is mapped from beginning to its natural conclusion, which can be observed by children's loss of interest (JI).

Joyce's Beliefs about Learning through Play

Joyce defined play as "children expressing themselves" (JI). She believed that play was children's expression of "their whole self, their holistic self, their culture, their ideas and experiences" (JI). Joyce described play as "urges" children had, of something they "wanted to do" or "repeat" because it was very "important" for them" to act on their urges" (JI). However, she emphasised that these urges were not "someone else's interest" rather it was their own interest, which was "meaningful" to the children themselves (JI).

Joyce stated that the "relationship between play and learning" was that during play "children's learning is made visible" (JI). Since it was their interest which "they act" on, it helps teachers to observe not only their interest but "assess their learning" (JI). She saw her role during play as a way to ensure she "extend" or "facilitate" the children through "engagement to reach their goals" (JI). However, Joyce felt that it was "difficult" or "tricky" 
for her at times to extend role play among children as it was sensitive and personal to them (JI). Therefore, to address this, Joyce would "problematise" the play to enable the children to come up with the extended play sessions, especially if the role play was about "family" (JI).

Learning through play is effective according to Joyce only if the "children's interests are considered" (JI). She added that it was important to "get the child's voice" into the planning stage, for example, "inviting the children" to tell her "what they like to do" (JI). Therefore, Joyce usually "talks" to the children to "find out" what they know and what they need and like $(\mathrm{JI})$. It is often Joyce "facilitating" them and finding out prior to the play activity so the children are able to "share" their interest with her (JI). Joyce stated that this process of "finding" out their interests, helps her "set up" and put out "resources" that would definitely "attract the children" (JI). Although Joyce believed children's "interest is important in play", she indicated that there also "should be structure" to benefit their learning $(\mathrm{JI})$. Joyce indicated that for the 4 to 5 -year olds in her centre, there was an "academic incline" to their resources to help them "transition" to primary schooling as it is important to teach them to live in a "structured world as well" (JI).

Joyce believed that there should be more play in the "primary curriculum" as this was "critical" to children's learning" and all the "academic stuff" was not as "valuable" (JI). Without enough importance being placed on "play in primary schools", she believed that children were not able to "express themselves" as they are able to in their "early years" (JI). Joyce added that primary teachers should be able to "pick up academic learning" while children are involved in play and "extend their learning from the play-based activities" (JI). In primary schools, she stressed, play would be "visible, observable" and enable teachers to "document learning" (JI). 
Joyce's understanding of assessing learning through play

Joyce said that she does not know what is "currently fashionable" for "assessing play" (JI). However, she believed it was "fundamental" that teachers assess children through "observations" but there were "various ways" of doing it $(\mathrm{JI})$. This variety of methods has become a "challenge" for teachers (JI). As a result, Joyce had "developed her own method of assessing the information on play" (JI). She stressed that the "method of assessing" was "noticing any child's" learning and progress and "documenting the process" (JI). For example, if she was "reading stories", documenting it through "photos" or "recording" she saw it is "a good way of assessing children's interest and learning" (JI).

Joyce believed assessing children in ECE should be "realistic" and not writing "an essay" each time you observe learning but about the "children's learning" (JI). It is a documentation of the "child's learning" that will inform the "goals for the children during the "next planning" stage. Joyce strongly believed "assessing" children's learning was "streamlining information" that was "relevant" rather than "talking too much" (JI). Observations and documentations of children's play should be "not about what is not happening" or "only picking out" what "a teacher wants to focus on in observations" (JI). Joyce believed it was about picking out from the Te Whāriki curriculum and the framework" and teachers distinguishing "the bolts and the strands" (JI). As a result, if it is done correctly, the "deeper learning" and the "relationship" between the child's learning can be "captured correctly" (JI).

Joyce added that she would sometimes "observe" to sense what was "happening or going on" rather than have "biased view of what is going on" (JI). She believed that this was due to having teachers' own thoughts of play and "customs of ways of playing" that had been "culturally constructed" though their own learning or "experiences" (JI). Joyce stressed that sometimes "joining in" the play with the children enables her to assess 
children more "efficiently" and that is "only practicable if the teacher is more experienced" (JI). She added that she does not "take over the play" but "feeds off" their ideas of "fun, [to] capture their interest" and assess their learning (JI).

\section{Practice and Observations}

Observations of Joyce's involvement in play activities took place over three consecutive days as Joyce requested.

Joyce's planning

Joyce's planning for the week:

"Provide [Child B] with opportunities to extend her friendships through sociodramatic play. Recently she has been playing with [Child A] and [Child C] in the dramatic playroom and engaging with the play materials such as the play food and cutlery. By continuing to provide [Child B] with opportunities to engage with these play resources, we can further support [Child B] as she plays with and alongside others who share this interest. Support children in the art area to work on ideas for their art and extend the ability to write their names on their own artwork. To support the further development of children's self-regulation skills during free play" (Jdoc).

\section{Observation Day 1}

Joyce sits in the dramatic playroom with the children she teaches who are aged two to five years. Joyce records the interactions between the children for their learning stories. During the first observation, children are playing with objects in the dramatic playroom. 
Children $A, B, C$ and $D$ are playing at the table in the dramatic playroom with pretend food items. They have toy food spread out on plates and are playing with and alongside each other.

Joyce: What do you have here? (She gestures to the food set on the plates. Child $B$ looks at Joyce and picks up a plate of food to show Joyce.

Child $D$ stretches out her hand to indicate that she wants the toys Child $B$ is playing with).

Joyce: (to Child D) You can have a turn once [Child B] is finished. We need to remember to share and wait our turn.

Joyce remains at the children's level, observing their play. Child B moves to get a mannequin's head used for dramatic play hair styling by the children. She passes it to Joyce. Joyce places it on the table and laughs.

Joyce: Oh dear! Can we help her with her hair? (Joyce and Child $B$ then work together to take out the plastic curlers from the mannequin's hair). How many hair curlers have you got? (Child $B$ looks at the hair curlers for a moment and then back at Joyce). Joyce: (begins counting and Child $B$ joins in) 1,2,3,4. We've got four curlers. (Child $B$ takes a brush and begins to brush the mannequin's hair. Joyce notices that Child $D$ is leaving the room with a toy that is supposed to stay in the dramatic playroom). Joyce:You give her hair a nice brush. l'll be back in a minute. (Joyce gets up and goes to Child D). Remember the kitchen toys need to stay in the dramatic playroom. (Child D listens to Joyce and returns the toys to the dramatic play kitchen set). Joyce: What are you drinking? Is it coffee? (to Child $A$ and the child nods).

Joyce continues to observe the play. Joyce discusses the different foods on the plate. She picks up each food from the plate and asked the children the name the item. For example, when she holds up a banana, the children say together "banana". This continues until the children have completed naming all the food on the table. She encourages sharing and turn taking while playing with the objects on the table.

Joyce: Are you sharing? Are you swapping? (she directs the question to Child $A$ and

$D$ who are both holding a plastic toy cash register. Child $D$ lets go of the toy and Joyce supports Child A). What button do you need to push? (both Joyce and Child 
A try pushing different buttons on the cash register until it opens). That is good. Now once you have finished playing with it, you can pass it to [Child D].

She observes the children playing with their peers and supports social interactions, such as turn taking and sharing. She does not initiate how they should be playing but sits as an observer with them. Joyce then informs the children that it was time to leave the room as it needs to be set up with beds for sleep time.

Joyce: Can we take these toys through to the block room? What toys shall we take?

(the children agree and collect the toy food and cutlery to take them to the block room).

Joyce goes to the block room taking some toys with her. Joyce places a blanket on the floor and the toys she brought with her on the floor.

Joyce: Ta-da, a picnic! Who wants a picnic? (Child A, B, C and $D$ join the play alongside Joyce).

Joyce: Wow, you have been playing with that for ages, I will have to remember that for tomorrow and get it out again (to Child $E$ who has been playing with the cash register).

Joyce and the children continue to play with the picnic set up and she remains supporting the children by encouraging them to share their toys.

Joyce: You may use the plate once [Child A] finished with that one (to Child B). Can we wait until [Child $C$ ] has finished playing with it until we have a turn? Are they grapes? Yum. Is that an apple? They continue play until it is the children's nap time.

\section{Observation Day 2}

Joyce moves to the main area where various puzzles are kept, the camera ready for recording. This section for play has books and boxes of construction toys. Joyce starts interaction with Child $A$ who has started a puzzle.

Joyce: Do you have all the pieces? (Child A looks around). Look there are some 
more (Child $A$ fetches the pieces and works on the puzzle for approximately 5 minutes before completing).

Joyce gets a box of various construction-type toys. She tips it onto the floor and sorts through all the pieces. Child $A$ joins Joyce.

Joyce: What shape is this?

Child A: Star (Joyce continues showing different objects and Child A identifies them.

The play reaches its conclusion when Child $A$ moves onto another activity).

Joyce then moves to the art area. Child C, D and E are engaged with the puzzles that Joyce has left for them.

Joyce: Can you try to complete the puzzles (she addresses Child $C, D$ and E. She picks one for the three of them and they sit around the puzzle).

Joyce notices Child B holding a piece of black paper.

Joyce: Do you want some chalk?

Child B: Yes (Joyce goes to get him chalk and Child B starts drawing on the paper and tries to create and image of a face. Joyce suggests that Child B could make a face out of playdough stamp. Joyce shows the child how to dip the stamp in paint then stamp on the paper. Child $B$ tries and looks pleased with the result). Joyce then moves to stop a disagreement between two children (Child $C$ and $D$ ) and reminds them to share and take turns. She invites Child A, C, D and E to do some artwork and paint.

Joyce: Wow that looks good (she says to Child $B$ and then takes the camera to document Child B's artwork). Tell me about what you have made. Look at that great piece of artwork (she shows it to Child $A, C, D$ and $E$ ).

Child $B$ : The mouth is open. It has big eyes and a small nose (describes the artwork proudly and enthusiastically to everyone).

Joyce: Would all of you like to try paint some faces? We could try different faces. Let's try sad, happy and different faces. Once you have completed it you can tell me what you have done (sits with the children as they try using the stamps and paint a picture on an easel).

Once the children have completed their artwork, they describe what they have done to Joyce. She then asked them to write their name on their artwork. 
Joyce: You start with the letters you know then I will help you write the rest.

The children then are asked to help clean up before afternoon tea.

\section{Observation Day 3}

Joyce and the children are in the outdoor play area. The children are playing on the swinging bar and Joyce plays alongside the children by swinging on the bars and making whooping sounds. The children laugh along with Joyce.

Two of the children, Child $C$ and $D$ decide to play with the Little Tikes ride-in car. They try to sit in the car together. Child $A$ approaches and joins in the play by trying to pull the car with a clip-on strap. Joyce notices this.

Joyce: Can you both really fit in there? Do you feel safe?

Child $C$ and $D$ reply they do, while Joyce continues to observe them. Child $A$ pulls the clip-on strap sharply, causing the car to topple over. Joyce goes quickly to check whether Child $C$ and $D$ are hurt. Joyce pulls the car upright.

Joyce: In think we should only have one person in the car at a time, don't you? (Child $D$ moves to another play area while Child $C$ hops back in the car while Child $A$ pulls it). Let's remember not to go too fast.

Joyce crouches to be able to observe the children better. Child B approaches Joyce and embraces her. Child $B$ has a bubble wand and pretends to blow bubbles which Joyce then pretends to pop by clapping her hands and saying "pop". Child B continues in this play, blowing bubbles. Child $\mathrm{E}$ appears wearing a mermaid costume and Joyce cautions the child about trying to climb wearing the costume as it restricts the ability to move. Joyce suggests that Child $E$ take off the costume and then come out to play. Joy reminds Child $C$ and $A$ to be safe while playing in the ride-in car. Joyce then decided to ask Child $B$ and $E$ who are now crouched down with her if they would like to jump. She then springs up in the air from the crouching position. Child B and E copy her movements and then Child $B$ resumes with the imaginary bubbles. 
Joyce notices two other children playing with toy cars near the equipment shed. Child $F$ has managed to get a toy car stuck under a wooden pallet near the equipment shed.

Child F: It is stuck!

Joyce: Why don't you try reaching underneath the pallet to get the car. Just do it carefully.

(Child $F$ follows her suggestions and retrieves the car). Well done.

Joyce observes Child $F$ and $G$ begin throwing the cars. She then suggests they instead construct a ramp for the cars to redirect their play.

Joyce: Shall we build a ramp? Let's see how we can do it. (Joyce gets a plastic spouting from the equipment shed). Where are you going to put the ramp? (Child $F$ and $G$ set up the plastic spouting on a raised garden bed). Well done both of you. Shall we see how the cars go on your ramp?

Child $F$ and $G$ are happy and push their cars down the ramp. They ask Joyce for more cars and she then asked them to get more from the sandpit equipment box. Child $\mathrm{H}$ takes an interest in the play and joins in. Joyce sets up another ramp and the three children take turns racing their car down the ramp. Joyce then requests that another teacher find more cars and the teacher brings a basket with various toy vehicles in them. Joyce then asks the children if they know the names of the vehicles and while they are playing, the children name the vehicles that are going down the ramp. Four more children join the play activity. Joyce gets more ramps set up. Joyce then sets a pipe as a ramp.

Joyce: Will this car fit through the pipe? (she holds a plane and shows the children before trying to put the plane in the pipe) Uh oh, it's stuck! How do we get it out? (Joyce gets a broom and tries to push the plane out with broom handle and gets the plane out).

The children continue the experiment with different size cars. Child $\mathrm{H}$ then takes one of the ramps and sets it up against a tree for a steeper incline. Joyce notices this and informs the other children about the steeper ramp. The children try different ramps that Joyce retrieved from the equipment shed before it is time to tidy up for lunch. 
Joyce's learning story documentation

Joyce had documented her observation of the children's learning during their play activities into their learning stories:

"[Child B] continues to display a strong interest in socio-dramatic play, using the play resources to enhance her play and support her interactions with others. She is using more language during these interactions and is displaying an understanding of the skills required to work with and alongside others, such as sharing and turn taking. Children are trying out different ideas in the art area, experimenting with materials. Many are continuing to practice writing their names, with encouragement from teachers. Children are being supported to think about what they are doing during play and the choices they make to extend the selfregulatory skills."

The relationship between Joyce's Beliefs and Practices

Joyce said her beliefs about play and assessment practices were influenced by "Centre B's philosophy of play, her own initiative, as well as learning through experience" (JI). However, she stressed that play should be learner-centred as it was an expression of "their whole self" (JI). Joyce's belief in "children's interest" as the centre of play was consistent during the observations as she selected play activities and extended the play activities based on the children's interest and how "they act" (JI, JO). For example, when she observed a child holding a mannequin's head, she used that interest to help the child count (JO). Her "observations of the children during play" helped her "interact with a child" and "scaffold their knowledge" (JI). 
Joyce stated that she "believed the child's voice" (JI) was important and "organising play activities" that they were "interested" (JI) in being beneficial was observed in her practice when she interacted with children (JO). In addition, by identifying their interests, she can "set up the resources to attract their interest" (JI) during play (JO). This was observed by her pre-setting the play area and children enjoying their play activities (JO). On the second day of the observation, Joyce's interaction with the children was asking the children to "tell her" (JI) what they were doing during the play activity session (JO). She then extended their play activity to add more details or show them different ways of doing something, but she never disrupted or stopped them doing what they enjoyed (JO). Her belief in "child-led activities" was observed as she supported children's self-directed imaginary play on day one. Joyce reported that she believed play should be learner centred with children taking an active role. She stated that play activities should be interactive and during the observation sessions encouraged children to explore and discover themselves based on their interests. Joyce's beliefs and practices aligned with the social constructivism theoretical framework by giving importance to social interactions, children's development, and language during play-based activities. She provided an interactive play environment. Her beliefs aligned with the features shared between cognitive constructivism and social constructivism such as taking into consideration the children's "interest" and their active role of exploring and discovering during play (JI).

Joyce's role during play was "learner centred" and she provided children with an interactive environment that supported their learning and extended the child-led activities. She used language to scaffold the interaction. She facilitated play and encouraged children to self-regulate their behaviour during interaction. For example, on day three Joyce supported the children playing in Little Tikes ride-in car by encouraging them to make safer choices in their play. Joyce's belief and practice relationships are shown in Figure 5.1. 


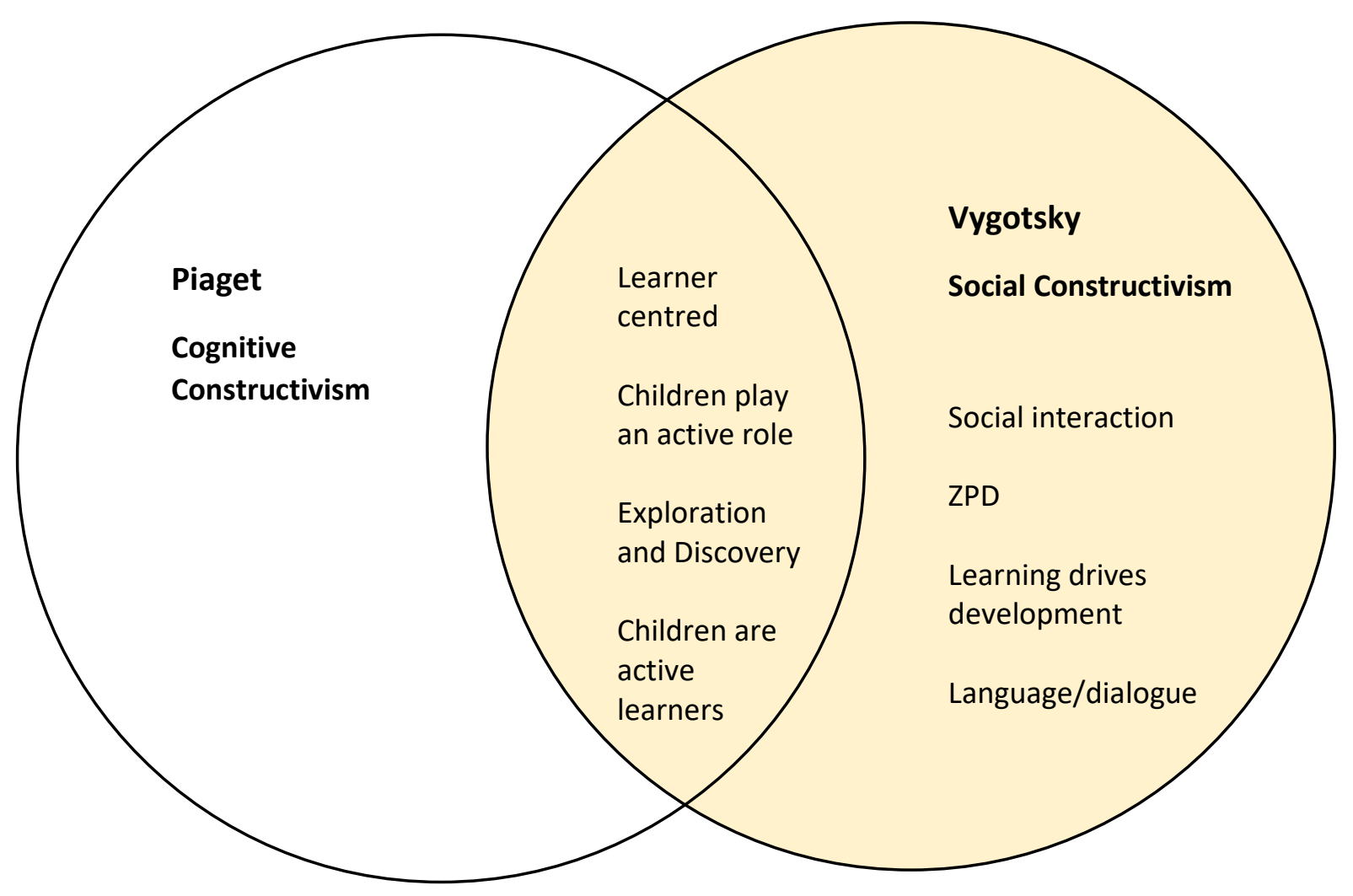

Figure 5.1: Joyce's reported beliefs and observed practice

\section{Themes}

\section{Child centred and teacher modelled facilitative play}

Data analysis of teacher interviews, observations, field notes and documents suggested that Joyce took on an active listener role in relation to what interested the children and provided suggestive play materials related to their interest as activities. She provided play activity experiences for children through her interaction and capturing their "interest" by actively "listening" to children's communication to peers or her "asking them" prior to the play session (JI). This allowed her to provide a modelled play structure to children. She provided stimulating and inviting play resources through her planning and discussions with other teachers. This enabled children to spend their play activity doing 
things that were "important, meaningful, and interesting" for them (JI). The children interacted with play resources and imaginary play activities that Joyce had prepared based on their "interests" (JI), with Joyce using those activities to extend children's learning when she felt "appropriate" (JI).

In addition to her play-based activities, Joyce demonstrated an activity to the children in order to "extend their interest" (JI). For example, on day three when the children were throwing the toy cars, she re-directed their energy by showing them how to build a ramp for their cars. She modelled the play and created a "fun" environment for the children. She did not restrict their creativity but encouraged the children to explore and experiment. However, she did use the play-based activity to consolidate their learning by asking them to name the various vehicles. She extended the play activity by enabling them to actively experiment with the resources.

Promote self-regulation through interactive facilitation during play

The promotion of "children's self-regulation" during play activities was another aspect Joyce highlighted in her interview (JI). She "did not directly help them" solve the problems but "extended the children's understanding" through interactive facilitation by suggesting possible solutions (JI). For example, when one of two children wanted to ride the Little Tikes car together, she did not stop them, but asked questions about safety. When the car toppled over, she reminded the children about speed and safety, so they are able to modify their behaviour through self-regulation and adhere to safety rules (JO).

She encourages children's self-regulation of their social competencies through observations of their behaviours. She reiterated concepts of sharing, turn taking, waiting 
for their turns, helping each other, and encouraging peers. She complimented good behaviour or a modification of their behaviour through self-regulation. She believed "deeper learning" is an important factor in play and through observations of children she was able to help modify behaviour by interacting with children. This was observed when Joyce supported the children's play on day three when redirecting their play from throwing toy cars to driving them down ramps (JO).

\section{Realistic assessment that streamlines relevant information}

Joyce stated that assessment was "fundamental" in ECE, but that she did not know what was "fashionable" and there were "various ways" of assessing (JI). She believed she did not know what is current to assess learning through play, but had knowledge there were various methods. She stated that observations were how she assessed children's learning. In addition, Joyce indicated that assessment should be realistic documentation of children's learning and only streamlined, relevant information on children's learning. To her, assessment was not "talking too much but picking out details" from the Te Whāriki curriculum and "documenting deeper learning" (JI). For example, in her planning for Child $B$, her goal was to provide opportunities to "extend friendships through sociodramatic play" (Jdoc). Her documented observation of Child B was that there was "progression towards attaining the goals set, by displaying skills required to work with peers" (Jdoc). In this she identified Child B's goal as engagement with resources and playing alongside others with similar interests. 


\section{CHAPTER SIX:}

\section{CASE STUDY THREE: RITA}

Introduction to Rita (pseudonym)

Background, education, and teaching experience

At the time of the research, Rita had been teaching for twenty years in the ECE Centre $\mathrm{C}$. She started working at Centre $\mathrm{C}$ as an untrained reliever and completed her Diploma in Teaching (ECEC) in 2011 with the centre's support (RI). She continued teaching in Centre $\mathrm{C}$ after her receiving her Diploma and her experience in teaching has been only from Centre $\mathrm{C}(\mathrm{RI})$.

Professional Learning and Development

The focus of much of Rita's professional learning has been weaving Te Whāriki curriculum and the framework into the teaching and learning practices $(\mathrm{RI})$. This has been done through the planned curriculum for the centre $(\mathrm{RI})$. Rita added that one focus of her professional learning and development has been embedding literacy and numeracy skills into the teaching and learning practices (RI). However, Rita stressed that none of the professional learning and development have been in the area of "how children learn" (RI). 
Rita's Early Education Centre (Centre C)

ECE Centre $C$ is a non-profit Christian-based centre, licensed for 45 children, including 25 children up to age 2 . The centre has seven qualified, full-time teachers (RW). Centre C's philosophy is underpinned by Christian beliefs and a focus on strong, positive relationship with families and the community (RW). The centre's value is having trusted relationships with each child and family and wanting to embed the 'our place' to become 'your place' value into children at the centre (RW).

The centre focuses on improving use of Te Reo Māori for instructions and daily routine and acknowledges the need for bicultural practices and to integrate Te Reo Māori across the curriculum (Rdoc). The centre emphasises allowing children to learn through play and provides individualised learning programmes based on each child's interest using a range of opportunities and experiences (RW). Te Whāriki is woven throughout the planned curriculum emphasising the learning partnership between teachers, parents, and families (Rdoc). This ensures "children are taught literacy and numeracy skills in an ageappropriate manner" (RI).

\section{Centre C's assessment practice}

Learning stories are written using the "StoryPark online portfolio system, with hardcopies printed out for the children's profile books" (RI). The "printed stories use the StoryPark templates for story layout" and "learning tags are added to connect to $T e$ Whāriki" (RI). Several of the stories focus on group learning/activities and highlight the learning of social skills such as cooperation and teamwork $(R O)$. The stories are written "in conversational style, often to the child themselves" (RI). The main room contains the 
Centre's planning board, which displays some of the current interests among the children $(R O)$. Interests are "grouped around the board with photographs of the children engaging in the activity" (RI), or photographs of the interest itself, such as wild animals (RO). There are small note pads available to add ideas, themes, or observations regarding these interests or any others that may be emerging $(\mathrm{RO})$.

Rita's Beliefs about Learning through Play

Rita defined play as "the life of a child" and "anything" the child is interested in (RI). She believed if play was planned around children's "interests" then they will be able to "soak up everything" during the play activities and it will "truly be a learning experience" $(\mathrm{RI})$. As a result, she believed children will get the most out of play and "enjoy" it as well. Joyce stressed that if they were "happy" and having "fun", they will "get more out of it" $(\mathrm{RI})$. She believed play was important for children when the move to "primary education as a continuity of learning" (RI).

According to Rita, play should consider children's "interests, competitiveness, ages and enjoyment" (RI). At Centre $\mathrm{C}$, teachers put their planning on the wall and during staff meetings $(\mathrm{RO})$, teachers try to "recognise" similarities and differences between the children's interest which then becomes their "focus when organising play-based activities" (RI). For example, Rita indicated that teachers "noticed" the children's interest in "constructions" as there was some construction work happening near the centre, so they made sure some of the "play activities involved construction type toys" (RI). Rita added to ensure "successful" learning through play, there should be adequate "resource available" for children (RI). 
While Rita found " $T e$ Whāriki a useful tool in assessing children's learning through play", at times she found the Centre's programme planning "frustrating" (RI). Rita stated that the teachers in the Centre "worked hard to plan and extend children's learning", but the "assessment aspect of programme planning" was at times "lacking" (RI). She believed that this was because of the "amount of paperwork required" made the "teaching team feel bogged down", which may lead to more shallow understandings of children's individual learning (RI). However, the use of Te Whāriki enabled Rita to "support what the children are already doing" without "dictating what learning should be occurring" (RI). Teachers, she believed "should meet the children's needs", so it is important to be able to "notice, respond" and "extend" their skills and knowledge during play (RI). Rita found it to be "interesting in thinking about these different approaches" as well as "instilling the centre's philosophy of play" (RI).

Rita's understanding of assessing learning through play

Rita indicated that it took her "four years" to learn about assessing children's learning and "what was behind", "what was happening" and "what worked" (RI). This has led to her believe that assessing children should be "holistic", "inclusive" and "a continuation of a building block of what the children are already doing" (RI). She stated that she "liked the Te Whāriki curriculum and the framework" and "using them to support" children learning was "beneficial" (RI). In addition, Rita felt that "assessing play" should always be from what "children are already doing" to how they have "progressed" (RI). Teacher "observations" are the "most important way to recognise if "learning has taken place" (RI).

Rita indicated that she "acquired her skills in assessing play" through "watching other teachers around her" (RI). She gained this knowledge through "seeing other teachers respectful and positive responses" to children's learning (RI). This included 
"watching, observing and learning" how children react to different strategies used by teachers to capture learning during play" (RI). She worked on her "foundation to build" her "philosophy, the reasons how and why it was important" and get the "deeper understanding" of "assessing children's learning in all aspects" (RI).

She believed that if "would be great" if the centre's "planning and assessment were brilliant" but, it has been a "struggle" as nothing really "stuck" in regard to planning practices (RI). Rita described the "programme planning" for the over Twos as "never being strong" although the "teachers work hard" during the "programme planning, building interest and extending the interest" of the children, but "the evidence and paper trail is not great" (RI).

Rita felt that learning through play should be "recorded" effectively, not just "watching children and having conversations" (RI). Assessing the "interactions" during the play and "documenting the learning" during the "interactions" are important (RI). Centre C used Storypark and Rita like the aspects of "building a community" but she disliked the "layout" and "all the stories" look "exactly the same" so she finds it "boring" format to use as printouts for the children's profile books (RI).

\section{Practice and Observations}

Rita's practice was observed three consecutive days as requested by Rita.

Rita's planning

Rita's planning for the week: 
"Support children's friendships during imaginary play. Continue to support children's sense of responsibility in caring for the learning environment by encouraging participation in care tasks such as tidying up after themselves. Encourage children to care for others while playing, keeping themselves and others safe" (Rdoc).

\section{Observation Day 1}

Child $\mathrm{N}$ and Child $\mathrm{H}$ are engaging in imaginary play, using dramatic play props to act as firefighters. Child $\mathrm{N}$ is struggling to put on a firefighter jacket which Rita notices. She approaches.

Rita: Where's the fire?! Quick put it on! (Rita helps Child N put his arm in the jacket and helps button it up. She then assists Child $\mathrm{H}$ to put on some firefighter pants).

Rita: Let's take your boots off first and then we can get the pants on more easily. (Child $H$ follows Rita's suggestion and takes off his gumboots. He then pulls the firefighter pants on and puts on his gumboots. Just then, a fire engine drives past Centre $C$, with its siren going)

Rita: Quick, quick, put out the fire! (Child $N$ and $H$ look excitedly at Rita and smile, before running outside to continue their play).

Rita then begins to set up one of the tables for indoor activities and sees Child $F$ standing alone.

Rita: What shall we put on this table? (Child F looks around thoughtfully and then points to a drawer that contains small play figures and furniture).

Rita: You want the dolls and furniture?

Child F: Yes.

Rita: Cool. Shall we put them on this table then? (Child $F$ nods, and then Rita and $F$ work together to place the dolls and furniture on the table).

Rita: Great work! Thanks for your help. 
Child $\mathrm{F}$ stays at the table to play with the dolls and furniture. Child $\mathrm{N}$ and $\mathrm{H}$ then return from playing outside and go to the dramatic play area. They continue their firefighter themed imaginary play, with Child $\mathrm{H}$ choosing a firefighter jacket to wear. Child $\mathrm{H}$ looks to Rita for help and she helps him to put on the jacket.

Rita: Did you put out the fire? (to Child $N$ and $H$ ). Will those boots protect your toes? (Child $N$ and $H$ look down at their gumboots and smile). What about your jackets? Do you think they will keep you safe from the fires?

Child N: Yes, they will!

Rita: Did you know they are having big fires in Australia right now? You could get on a plane and help fight the fires. (Rita takes her phone and opens to YouTube to find appropriate videos for the children to watch. (She finds one and sits down with the children. Child $\mathrm{N}$ and $\mathrm{H}$ move to see the video and are joined by Child $T$ and $R$ ). Can you see they are using helicopters to put out the fire?

Child T: I'm going to put out that fire!

Rita: What do you think you could use to put out the fire?

Child N: Water!

Child H: And a helicopter!

Rita: A helicopter. That's a good idea.

Child H: Let's go! (Child H moves to the outdoor area and is followed by Child N. They continue to engage in their imaginary play of fighting fires.

Rita was the designated indoor teacher and moves to assist in the art area and sees Child $B$ and Child A drawing. She asks them to describe their artwork and helped them write their names. The children then help Rita put the stuff away to get ready for morning tea.

\section{Observation Day 2}

Rita has set up the block area and observes children A, B and C playing. The children have constructed various buildings and have used toy cars as part of their play. The children then decide to move to another area. 
Rita: Remember to put your blocks away please, tamariki. Would you like some help (Children A, B and C agree to Rita's offer of help. Rita approaches the block area and crouches down to assist the children in tidying up. Rita encourages the children to tidy up). Do you want to put the long blocks away? (to Child $C$ and Rita points to an area of the room where there are several long blocks). Look! There are some over there (Child C collects the blocks and places them on the shelf). That's it, Ka pai.

The children and Rita work together to collect the blocks and put them on the block shelf. Child $B$ points to an area of the construction room, where one of the small buildings are. Child B: Look! That's the lava (pointing to the construction room).

Rita:Yes, and that's the lava coming out of the volcano.

Child A: And it's going to burn those cars (points to some toy cars near the 'lava' to Rita).

Rita: Oh dear. Are the cars going to move out of the way?

Child B: Yeah.

Rita continues to support the children as they tidy up the construction area. Child $A$ and $\mathrm{C}$ pass some blocks to Rita to place on the shelf.

Rita: Thank you. Shall we count the blocks as we put them away? (Rita counts slowly in Te Reo as she places the blocks on the shelf). Tahi, rua, toru... what comes after toru? Do you remember?

Child $B$ and Child $C$ : Whā.

Rita: That's right, ka pai. High five! (Rita motions for the children to give her a high five by holding up her hand. The children then give her a high five, one by one. Child C's parent then arrives to collect Child $C$ to take home).

Rita: Wow [Child C], look whose here! Why are you getting picked up so early?

Child C: I'm going trick or treating for Halloween.

Rita: Wow, that sounds fun. What are you going to dress up as?

Child C: A red Power Ranger!

Rita: Cool. Have fun. Bye. (Rita waves to Child C).

Child C: Bye Rita.

Rita then continues to work with Child $A$ and $B$ to finish tidying up the construction area. 


\section{Observation Day 3}

Rita moves to the outdoor area to relieve one of the other teachers for their break. As she moves outside, a younger child (Child A) trips over on the matting and begins to cry. Rita moves to Child $A$ and crouches down to the child's level.

Rita: Oh dear, did you fall over? (Child A nods. Rita offers two small balls to Child A, who takes them from Rita). Would you like a cuddle? (Child A nods, so Rita picks her up and gives her a cuddle. Rita carries Child $A$ to where several children are playing and sits nearby so she can observe the play area, nursing Child $A$ on her knee).

Two older children (Child J and S) approach Rita.

Child J: I went trick or treating last night, Rita!

Child S: Me too! I went as Cat Boy!

Rita: Cool. What did you dress up as?

Child J: I went as Paw Patrol! (Child J turns to Child S). Let's play Paw Patrol! (Child

$S$ smiles and the two run off together. Rita looks at Child $A$, who is still sitting on her knee).

Rita: Would you like to go on the slide? (Child A nods, so Rita places her off her knee).

Child A walks towards the climbing equipment, with Rita following behind her. Child A begins to climb a small climbing box, which is attached to the rest of the climbing equipment and slide. Child A hesitates, so Rita encourages her.

Rita: Put your feet there and your hands there. (Rita directs Child A's attention to the foot and hand holes in the climbing box. Child A follows Rita's directions and slowly climbs up the climbing box).

Rita: That's it, Ka pai! (Child $A$ stands on the climbing box looking pleased with her efforts. Rita smiles back and claps). Yay!

Rita continues to observe Child $A$ on the climbing equipment, along with the other children in the area. Child B rushes past, pushing a large toy truck along the ground. Rita looks at Child $B$ and reminds him to be careful.

Rita: Be careful. You get so fast pushing that truck around. Remember what 
happened when you went too fast around the corner? (Child B pauses and looks at Rita).

Child B: I crashed! (He looks at her excitedly as he recounts this incident).

Rita: That's right and you hurt your leg, didn't you? What are you transporting in your truck? (Child B smiles but doesn't answer. Rita suggests some possible answers to her question, in order to prompt a response). Is it chocolate? Is it pirates? Is it cars?

Child B: No, it's rocks. (He laughs continues to push his truck around the playground). Rita continues to observe the children in the area and encourage Child A with her climbing. Rita then asks the children to put away their toys and get ready for their afternoon tea.

Rita's learning story documentation

Rita had documented her observation of the children during their play and learning in their learning stories:

"We have watched [Child $\mathrm{H}$ ] and [Child N] playing together this week in imaginary fire fighter play. We have encouraged them to share and take turns with the play resources and include others in their play. We have continued to support [Child C] in further developing his sense of responsibility in caring for the learning environment. [Child C] really enjoys the construction area and uses a lot of the equipment when building. He still needs reminding to tidy up but is more willing to help when he needs to. We will continue to support [Child B] to make better choices when playing, reminding him keep himself safe" (Rdoc). 
The relationship between Rita's Beliefs and Practices

Rita's said her beliefs about play and assessment practices were "influenced by the professional learning and development she gained through Centre $\mathrm{C}$ and her own teaching experience" (RI). Rita described play as "the life of a child", suggesting that it "should be interesting" (RI). She said that it enables children to "gain a learning experience and at the same time be fun" (RI). To support play and learning, she indicated that she provided a "socially organised environment" (RI) and engaged with children through "facilitation" (RI). In addition, she provided opportunities for children to explore and discover knowledge through scaffolding and based on their own interest, such as extending the children's knowledge of firefighters through YouTube (RO). However, during the observation she had limited teacher-engagement with the play activities and remained an outsider observing their interactions with peers and play $(\mathrm{RO})$.

Rita's espoused belief of play and her practices differed in certain aspects. Although Rita indicated she was "still learning" and "frustrated about effective planning and assessing children and documenting learning" (RI), the observations showed children having fun and she had extended their play-activities to develop their self-regulating skills (RO). However, all the observations showed that she had close relationships with the children as they were seen talking about "going to the movies, "enjoying a birthday party" and talking about their home activities with her $(\mathrm{RO})$. During the three observation sessions, she showed the ability to engage in their free play, self-selected activities or planned activities effectively as children constantly came and interacted with her or talked about their activities once they went home the previous day (RO). For example, when the children decided to role play as firefighters, she encouraged them and developed their knowledge about putting out fires, by scaffolding and interacting with the learners $(R O)$. Rita was able to include a teaching moment on current affairs about the Australian fire by quickly showing them videos on YouTube (RO). 
Rita's belief that learning through play was "continuation of a building block" (RI) was observed in her practice during the firefighter role play as more children became involved in the play and she was able to add to their existing knowledge (RO). Her observation of the children's interest enabled her to progress and support their own interest $(\mathrm{RO})$. She built on and encouraged their interest in construction, by displaying construction vehicle toys. She created a play environment "similar to one on a construction site" (RI).

Rita believed she was "struggling", "still learning" and "frustrated" while trying to "implement play and assessing the learning" (RI). However, during the three observations of her teaching practices, she was able to engage with the children; choose materials children were interested in; and extend their knowledge effectively (RO). She had also documented the children's outcomes after the activities to be included in their learning stories (Rdoc). Rita's beliefs and practices leaned towards the social constructivism theoretical framework. She interacted with the children to learn about their interests and her play activities were learner-centred. Her role during play was a facilitator who limited her engagement in the play activities. She supported the learners by scaffolding within the socially organised environment. Rita's belief and practice relationships are shown in Figure 6.1. 


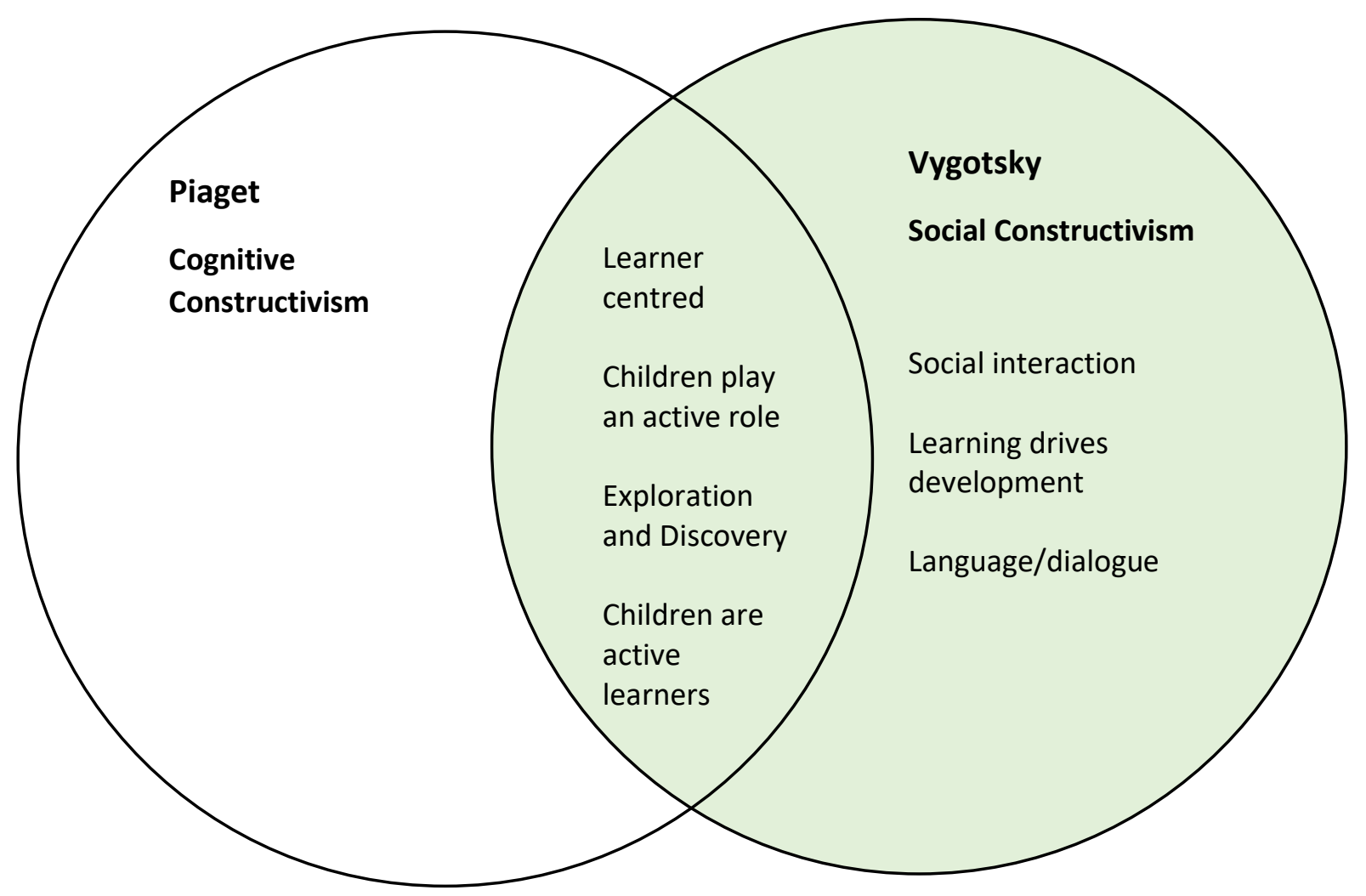

Figure 6.1: Rita's reported beliefs and observed practice

\section{Themes}

Data analysis of Rita's interviews, observations, field notes and written documentation suggested Rita assumed what might be described as an active facilitator role during play by setting up the play environment, materials, and props for the children. Through her interactions and observations of the children, she captured the interest of the children. As she believed that was important for teachers to consider "interests, competitiveness, ages, and enjoyment" (RI) when selecting play activities, she set up the play environment, so children were able to engage in what interested them. She ensured it build on what they already knew to maintain "continuity" in their learning (RI). 
Although she set up the props for role play, children chose based on their interests and she engaged with them through interaction in role play activities. She prompted children with questions and initiated communication to facilitate their play, to make it fun, and add dramatic elements to it. For example, encouraging the role play of firefighters to make it similar to real life situations for the children. Rita embraced the facilitator role during each observed play activity and used language to scaffold the children's learning and extend their knowledge.

\section{A holistic assessment practice}

Rita believed that ECE assessment should assess children's learning through play in a "holistic method that is inclusive" and consider what was behind the learning, what was currently happening, and what worked $(\mathrm{Rl})$. Her assessment practice includes noticing, responding, and extending a child's skill and knowledge during play as assessment should be of the "child's building block of knowledge" (RI). Her assessment practice was inclusive of the "centre's philosophy of play" and thinking of the "various approaches" but it took her four years to gain confidence in assessing children's learning (RI). Learning the "approaches to assessment had been a frustrating journey" as although she had done so "by watching other teachers using the different strategies, she still "struggled to capture the learning aspect during play" (RI). Rita indicated that she would like "a consistent plan or strategy" on how to assess learning (RI).

Rita's weekly planning for learning through play mostly focused on a designated group of children, with some individual children's learning goals stated (Rdoc). For example, her learning through play planning indicates that her role is to support children's "sense of responsibility in caring for the learning environment" which included tidying up (RI). The analysis of the learning stories document however, was specific to individual children. Observation of her practice and her learning story documentation indicated that teachers "continued to support [Child C] in further developing his sense of responsibility 
in caring for the learning environment" and "needs reminding to tidy up and more willing to help" (RI). Another example of specific child documentation was that "[Child $\mathrm{H}]$ and [Child N] played together in an imaginary firefighter play" (RO). She added that "we have encouraged them to share and take turns with play resources and include others in their play" (RI). Observation of individual's continuity of learning for the week was holistic and broad learning goals for the whole group were not captured in the learning stories (Rdoc). Teachers used their "inside knowledge" for the learning stories as they knew the "children individually" and what "each needed to learn during the play activities"(RI). 


\section{CHAPTER SEVEN:}

\section{DISCUSSION}

In this chapter, the findings of this research are discussed in relation to teachers' beliefs and practice about learning through play. The first section explores teachers' beliefs surrounding play and its role in learning. The relationship between teachers' beliefs and their practice is then examined, followed by a look at how teachers' beliefs shape their approach to assessment.

Teachers beliefs about the role of play in children's learning

The teachers in this study had similarities and differences when describing play and its role in children's learning. Teachers' beliefs and assumptions were influenced by contextual factors such as the differing centre philosophies and goals, limited professional development opportunities, challenges of working with multifaceted ideas about play and children's learning.

Differing definitions and understanding of play

Teachers in this research had varying definitions and understanding about learning play. Geoff defined play as a "children's interaction with the world around them" and had the understanding play should be the "forefront of their day" (GI). He believes that play is how children learn about "their world" and to role model their "views" (GI). Joyce defined play as "children expressing themselves" with the understanding that play was children's expression of their "whole self, holistic self, their culture, their ideas and experiences" (JI). Joyce added that play was "urges" of children wanting to "do or repeat" because it was important to them (JI). Rita defined play as the "life of a child" and "anything the child is 
interested in" this she saw and enabling them to "soak up everything" and have "truly learning experience" (RI). These indicate that all three teachers' beliefs and understanding of play fall heavily within a constructivist world view, that play is learnercentred and is meaningful and important to the children (Piaget,1973; Vygotsky, 1967).

While researchers are attempting to generate definitions to reflect the complexities of play, inconsistent definitions among teachers are a result of looking at play through differing theoretical lenses (Alcock \& Stobbs, 2019; Pelligrini, 2013; Nuttall, 2003). Research indicates that a teacher's definition and understanding of play is context specific, complex, and influenced by the learning environment and their beliefs (Wood \& Attfield, 2005). This was evident in this research as the findings revealed there were various definitions of play and differing understandings about play and learning.

The teachers in this research all shared the view that "play was important to children" (GI, JI,RI). All three teachers believed that play and learning go hand in hand and that it was important in children's learning and development. Research indicates that differing definitions and understanding are a result of the teacher's individual knowledge and understanding of play (Baker, 2014; Howard, 2010). This research has shown that teachers hold differing and complex definitions and understanding of play in the ECE. Therefore, there is a need to provide support to ECE teachers to help them gain a deeper understanding of play within the curriculum so they are able to navigate their play pedagogy to align more closely with the New Zealand Te Whāriki curriculum and framework of a child-centred learning (Howard, 2010; Leggett \& Ford, 2013; MOE, 2017).

Varied understanding of the role of play in learning

All three teachers in this research reported that play was beneficial and should be incorporated into the curriculum. Geoff highlighted a relationship between play and 
learning by "identifying the benefits such as developing children's learning styles, language, cognitive function, social-emotional skills, and social competency" (GI). Geoff indicated that play was the "forefront of all planning" and incorporated into different aspects of the children's day so they "learn about the world" (GI). The other two teacher participants, Joyce and Rita, highlighted the role of play in children's learning in a more general way. Joyce reported that the role of play was to "inspire children to become courageous investigators" and that play was "absolutely fundamental" to children's learning $(\mathrm{JI})$. Although Joyce did not report specific benefits of play, observation sessions revealed Joyce encouraged children to self-regulate their behaviour during interactions by identifying acceptable behaviour. Rita reported that she believed that if children are able to engage in play in a safe and nurturing environment that "they will get more out of it" (RI).

Studies indicate the role of play in supporting learning (Alcock \& Stobbs, 2019; Moore et al., 2014) and helping to improve children's social, cognitive and language skills (Nuttall, 2003; Saracho \& Spodek, 2006). Teachers' guidance and interaction help to promote learning through play. However, the open nature of the Te Whāriki curriculum seats the responsibility on teachers to facilitate children's learning (Nuttall, 2003) and this has been the 'gap' in teachers' understanding about the role of play and its relationship to learning (Blaiklock, 2010; 2018). This research has made this 'gap' visible and revealed differences in understanding between teachers on the role of play in learning, with teachers holding diverse and complex beliefs on learning through play (Geoff, Joyce and Rita).

This is another example where differences in teachers' understanding of the role of play and learning in ECE should be addressed. There were significant differences in the teachers' understanding about the role of play and learning, from one teacher being very specific and the other two teachers having a more generalised understanding. Teachers reported that there was a lack of professional development and learning 
opportunities to help them understand learning through play and assessing learning. A key finding from research conducted on the understanding of play and learning has been the need to build on teachers' knowledge through professional development courses (Hedges \& Cullen, 2005; Mitchell et al., 2008). This could potentially support teachers in New Zealand ECE to develop a more robust and in-depth understanding about the relationship between the role of play in developing children's learning.

The Relationship between Teachers' Beliefs and their Practice

In this research there were distinctive differences between teachers in their practices and assessing learning as a result of their beliefs and understanding of learning through play. The teacher participants made reference to the complexity of incorporating play into the curriculum and assessing children's learning through play ( $\mathrm{Gl}, \mathrm{Jl}, \mathrm{RI}$ ). Due to the complex nature of assessing learning through play, teachers' beliefs varied, as did their role in children's play. While some studies provide evidence that teachers' beliefs influence their practice (Hedge \& Cassidy, 2009; Hedges \& Cullen, 2005; Oppermann et al., 2019), other studies have revealed inconsistencies between teachers' espoused beliefs and their practice (Blaiklock, 2013). For example, Farquhar's (2012) study highlighted that although teachers had adopted aspects associated with learning through play practice, there were distinctive differences between their practice.

The flow of play: The role of insider and outsider

Teachers in this research had different views about learning through play and the ways by which to involve themselves in children's play. In this research, one teacher (Geoff) believed that it was important to engage with the child in the "child's world" and to "support their learning" (Gl). During observations, Geoff was often an 'insider' and took on the role of a participant in the play while contributing actively to the flow and the 
direction of the play. Any extension of knowledge during play was as a result of his observation and his perception of the need to teach language. He prompted and interacted with the children throughout the observed practice, scaffolding their competency in learning the vocabulary. By comparison, both the other two teachers (Joyce and Rita) were more 'outsiders' of the flow during play. They tended to not get involved in the play but prompted the direction of play activities from the side-lines. This modified the play in which the children were involved, and the teachers were able to extend the children's learning through bringing in new knowledge or adding to their current knowledge. Both teachers believed that their role during play should be largely "facilitation" that ensured teachers were able to "meet the need" of a child (JI, RI). One example of this was when Joyce built a ramp for the toy cars to enable children to selfregulate their behaviour. Another was when Rita extended the children's firefighter roleplay by showing them videos of the bushfires in Australia.

Kagan (1990) indicated teachers' beliefs influence the implementation of play in ECE. They can take on the role of observer, facilitator, mediator, or participant (Jones \& Reynolds, 1992). There are teachers who perceive their role in play is to facilitate the play, but others view their role as being involved in the play, often when they believe there should be some structure to play and orientate children towards learning (Hadley, 2002). These findings are consistent to research findings that teachers play a significant role in providing opportunities for children to engage in discovery and inquiry (Aras, 2016; Clark \& Kragler, 2005; Edwards, 2016) and make the children's learning meaningful (Farquhar, 2012; McLachlan, 2018; Zhang, 2017).

In this research, a theorised explanation for the different roles and approaches taken by teachers when implementing play and assessment strategies is that they are due to the teachers' own beliefs of how and what learning happens (Alcock \& Stobbs, 2019; Howard, 2010). These reflect differing understandings that teachers held about play, learning and approach to assessment in this research (Blaiklock, 2013; Fang, 1996). 
Therefore, it is important for teachers take into consideration the 'how' and 'from whom' they receive information on play, to gain a deeper understanding about their roles during play (Leggett \& Ford, 2010).

\section{Teacher Roles: Teacher 'guided' or 'child-led' activities}

Research on teachers' beliefs and practice reveal that although teachers reported children's freedom to choose their play activities based on their interest, observed practice indicated otherwise (Wood \& Bennett, 2000). Teachers' roles during the play activities varied between ECE centres (Wood, 2007; 2009; Hedges, 2014; Hedges \& Cooper 2016; 2018). All the teachers in this research espoused the belief that children's interests were the core of their planning and implementation of learning through play, however observations of play and observed practice revealed that the role of play, the teacher's role, the environment and the context varied.

Whichever role the teachers embraced, outsider or insider in the flow of play, they took on several roles to ensure play was effective. In this research all three teachers took on the role of a facilitator, providing play materials, however, only one teacher (Geoff) played a greater role in guiding the play activities. The other two teachers (Joyce and Rita) set up the materials in the designated play area and the children were able to play by choosing their materials of interest. Although all three participant teachers indicated they believed in "children's interest" and "learner centred" (GI,JI, RI), Geoff often played a greater role in guiding and supporting the play due to the age of the children participating.

Both Joyce and Rita facilitated and extended the individual child's interest during play and scaffolded their knowledge specifically on the children's observed play activity. However, all three participant teachers acted as mediators offering new materials or 
suggesting substitutions for disputed materials or roles. In this role the teachers modelled flexible thinking and problem-solving through interactions (McArdle, 2001). Geoff's role as a mediator was limited during the observations due to the age of the children, with Geoff being prompted to take more of a lead role in the interactions. Geoff tried to intervene and create interest by getting involved in the materials and activities by organising a much greater number of teachers-led activities (Cutter-Mackenzie \& Edwards, 2013; Edwards \& Cutter-Mackenzie, 2013).

Contrastingly, both Joyce and Rita stated that play should be around children's interests and all the play activities observed were considerably more child-led. They promoted social development and self-regulation to ensure acceptable behaviour by children during play and with their peers. The teachers made various comments to extend the child-led play activities. Both teachers were observed using facilitative interactions to enable children to successfully scaffold their learning and extend their play (Vygotsky,1978). The overall findings are consistent with other research which suggests that differences in teacher's beliefs and practices are related to dissimilarities in relation to their definition of play (Alcock \& Stobbs, 2019; Baker, 2014).

\section{Diverse understanding about assessment approaches}

The strength of the Te Whāriki curriculum enables wide-ranging principles and objectives to be used to assess children's learning and development (Eberle, 2014). However, the curriculum enables teachers assessing during play activities to be open to different possibilities and outcomes (Bernstein, 2000; Dalli, 2011). Due to the lack of emphasis on subject content knowledge in Te Whāriki, teachers' described curriculum planning and pedagogical approaches which were consistent with their individual 
interpretation of curriculum as focussed on the "learning" (Geoff, Joyce and Rita) as opposed to the content when implementing the play activities.

During the research, participants reported that they believed in the value of play as tool, or medium of learning. Through play, teachers reported children making observable achievement. However, there were variations from their planning to their assessment on the learning goals for the children, depending on whether the planning was by the teachers, centre wide or from teacher/parent discussions. All three teachers had pre-planned some of the play activities based on children's interests, recurrently enacting goals and assessment to measure the learning. All teachers reported they used "observations and learning stories" in their assessment approach (Geoff, Joyce, Rita).

The findings of this research revealed all three teachers believed that assessing learning through play was important and associated learning stories with assessment. However, Geoff reported that for him, assessment was a self-exploration of his teaching practices. It was important for him to continually think about children and their development during the assessment. He reported that by placing himself with the children during the play, he was able to enhance their learning, improve their understanding and put ownership back to them through observations. Geoff emphasised that this enabled him to understand and observe the transition and acquisition of language.

By contrast, Joyce and Rita indicated that they sometimes struggle to understand assessment of learning and how to measure if learning was taking place. Joyce believed that assessment of learning through play should be realistic and she had developed her own strategies that enabled her to streamline relevant information. She indicated it that it required "understanding the bolts and strands of the Te Whāriki curriculum and framework to capture the deeper learning" (RI). Rita reported that assessing learning during play should be inclusive and holistic and a continuation of a building blocks. Rita added that it is crucial for teacher to recognise learning has taken place. Both Joyce and Rita indicated 
that their acquired skills and understanding of assessing play were developed through observation of other teachers and talking to their colleagues. However, Rita was the only teacher who reported she had to build her foundation and philosophy on why it was important to assess children's learning and she had struggled to gain the understanding.

It is theorised that this is partly due to the openness of the Te Whāriki curriculum and framework which means that responsibility is held in the hands of the teachers. Due to the different possibilities and complexities of identifying learning through play (Brown, 2004), it is therefore significant for teachers to upskill their own understanding and knowledge on assessment to enable them to implement play and observe learning effectively (ERO, 2007; Farquhar, 2003). As evidenced in the findings, the practice of all three teachers was strongly shaped by their own experiences and a 'trial and error' process that influenced their beliefs on best practice. As a result, ECE teachers who try to navigate the two different constructs, play and learning, are left with having to mitigate between developmentally appropriate play as well as the expectation placed on them by the Te Whâriki curriculum and framework of the role of child-centred learning during play (Blaiklock, 2013; Farquhar, 2012; Hedges \& Cooper, 2016).

Teacher beliefs connected to distinctive assessment approaches and practice

All three teachers indicated their approach to assessing learning during play was through observations, learning stories, and anecdotal records (GI, Jl, RI). The observation data revealed teachers took photos and video recordings of the play sessions (GO, JO, $\mathrm{RO}$ ). While the findings of this research revealed that teachers were confident in their approach towards assessing through observations, each teacher's approach was distinctive. Geoff believed all children should have goals set for them which can be achieved during play. This belief was observed during his planning, when he described 
setting an environment that encourages exploration in an independent manner and provides opportunities for social interaction. His planning of play activities was not individualised for each child, but his learning stories documentation highlighted Child $\mathrm{C}$ developing closer relationships with another peer. All three observations of Geoff's practice during play activities showed him engage with children and ensure that language development was a priority. In working with under Twos, he put particular emphasis on children's gestures and body language to capture their learning. Geoff espoused beliefs about assessment and the importance and benefits of assessing children were observed in his practice and learning stories, though as described above, not always in his planning.

Joyce planned individual learning goals for the children. She documented what the children had already been doing and how she was going to extend their learning during play. For example, Joyce indicated that Child B would be provided opportunities to extend her friendship through socio-dramatic play being supported to work alongside other children with similar interests. Joyce also indicated that she saw play activity as an opportunity to further develop children's self-regulation skills. Joyce's observation and documentation in Child B's learning story was that there was progression towards attainment of goals. Joyce beliefs about streamlining only relevant information about children's learning during play was consistent and observed in her approach and assessment practice.

Rita believed that there was a continuum assessing learning through play as it should begin with what children already know and if learning had taken place. She reported that assessing should be holistic and inclusive. However, Rita was critical of the paper trail required and although she believed it is important for documenting children's learning. She also found the StoryPark layout too limiting and standardised. Rita's goals or support and encouragement reflected goals that she had set for herself and what she would be doing for children to attain learning. However, in her learning story, she was very specific that Child $C$ needed to develop a sense of responsibility and caring for the 
environment. Another individual attainment observed in the learning stories was about Child $\mathrm{H}$ and $\mathrm{N}$ playing together but needing to learn to share and take turns.

All three teachers in this research used both formal and informal methods, such as observation and learning stories, to gather information. In documenting children's learning through play, it may be wise for educators to focus their attention on Carr's (1998a; 1998b) idea of learning dispositions. Each of the five learning dispositions is connected to one of Te Whāriki's strands, with a specific behaviour providing the focal point when assessing children's learning. Focussing on the learning dispositions while assessing children's learning can enable educators to assess how children learn while engaged in various play activities, and therefore plan and implement an inclusive curriculum more effectively. Such an approach will require educators to look beyond resources, activities, and equipment for more complex understandings of children's interests.

The findings of this research also reveal that teachers' beliefs and understanding about learning through play and assessment have been developed through their own experience and strongly influenced by their centre and colleagues. Given their knowledge was socially constructed (Bubikova-Moan, Næss Hjetland \& Wollscheid, 2019; Bodrova, 2003; Charlesworth et al., 1991) teachers' experience and learning from others make significant contributions to their knowledge about assessment approaches and their practice. However, there can be challenges when teachers have to rely on their own experiences and engagement with peers to mentor and inform them about good assessment approaches, as it may not always lead to quality of practice (Reynolds, 2007). 


\section{CHAPTER EIGHT:}

\section{CONCLUSION}

\section{Summary of Research Findings}

This research reflects three important areas of complication for implementing learning through play: firstly, there were significant differences among teachers when they reported their understanding of play, learning and assessment and their practices. Secondly, these differences can be understood in terms of the individual teacher's contexts. For example, their ECE centre's philosophies, collegial support, and interactions and each teacher's professional learning and development experiences. Lastly emphasis on and implementation of learning through play and approaches to assessments may be limited by the influence of a teacher's pedagogical knowledge and skills.

These findings of this research suggest that the teachers in this study believed in learning through play, and that their beliefs about play and learning as assessment approaches, play a significant role in their practice. However, their definition and understanding of play varied and they experienced challenges in developing their assessment practice in regard to learning through play.

The findings indicate that teachers were conceptualising and planning learning goals for children, however planning and implementation of individual goals and addressing achievement of learning outcomes for the children presented challenges. This study highlights the need for greater consideration of how teachers might frame learning goals and competencies as part of their learning through play practices. Perhaps, this might best be achieved through a comprehensive and nationwide approach to professional learning and development. 
This study, like others, has highlighted a complex interplay between beliefs and practice. This included both consistencies and inconsistencies between teacher belief and practice. For example, the teachers in this study espoused their beliefs about childcentred play activities and children's interests being their focus during the planning and the enactment of play activities, but this was not always the case. For example, in the priority put during play activities on social and language learning. This contradiction may have resulted from teachers' complex understanding of play, learning and assessment. The conclusion of this study is that the relationship between teachers' beliefs and practice should not be underestimated. In fact, this interplay should be investigated further, as it will likely reveal important indicators of the specific way teachers' knowledge indirectly influences children's learning.

\section{Implication}

This research indicates that teachers have multifaceted understandings about learning through play and approaches to sound assessment practices. Therefore, serious consideration must be given to any gaps that may exist in teachers' understanding, knowledge and their practice of learning through play. The implications of this research are considered in relation to teachers' learning through play practice and their professional development. This is a small-scale study and I have stated, while cross-case analysis is intended, to suggest broader implications and make generalisations is problematic.

\section{Teachers' professional development}

There is a range of professional development opportunities available for ECE teachers, however not all teachers embrace professional learning and development 
programmes and each ECE centre is free to choose the PD they want their teachers to attend or how the PD should be run. Ad hoc professional development allows the teachers to practice their own interpretation of implementation of learning through play and approaches to assessment.

The findings of this research have highlighted how both ECE teachers' beliefs and practice may be influenced by the centre they work in, their mentors, and by their professional learning and development. Teachers' definition and understanding of play and learning was influenced by all these factors, specifically their approach to assessing learning and learning goals for children. The indication that PD has to power to change teachers' beliefs and practice is further incentive to engage the teachers in professional development about learning through play and the Te Whāriki curriculum. Although PD is not a quick fix that immediately improves teachers' existing knowledge and practice, it can enhance knowledge and confidence in play-based activities, learning and approaches to assessing learning.

Teachers engaged in PD need continuous support and opportunities to reflect on their practice and examine how outmoded ideas and assumptions can be transferred to meet current practice. Furthermore, if teachers want to make play-based activities children-centred, attention must be paid to developing teachers' knowledge, understanding and skills for utilising play as a learning tool. As discussed in Chapter Seven, the teachers' espoused and tacitly held beliefs were influential on their practice and approach to assessment during play-based activities and learning. Therefore, it is important that those who run PD programmes encourage teachers to examine their deepseated beliefs. The enactment of PD, while gradual and challenging (Guskey, 2002), is acknowledged to some influence on teacher change. Those organising ECE teachers' professional learning and development must pay attention to helping teachers gain skills about learning through play and approaches to assessing children's learning. 


\section{Limitation of the Study}

Lev Vygotsky (1978) and Jean Piaget (1973) proposed theorisation of learning through play is an attempt to offer a broader perspective on effective learning through play practice that involved a child-centred approach. According to the constructivist theories, children are put in the spotlight, however the focus of the teacher's role should be concerned with more as a facilitator who encourages discovery and exploration, while extending the children's knowledge based on their own interests. Although Vygotsky's and Piaget's theory were consistent with effective learning through play concepts, there is a need to reposition learning through play within a wider framework that consists of self-regulation theories, motivational theories, as well as behavioural and cognitive theories. Therefore, further research focusing on all the aspects of teacher's efficacy beliefs, children's self-regulation, cognitive development, and motivation in relation to learning through play would be a valuable contribution for future research.

\section{Future Research Directions}

This research aimed to provide a rich description of teachers' beliefs and practices on learning through play and their approach to assessment. As explained in Chapter Three, this research was both limited and small scale, therefore there is a need for more qualitative studies detailing New Zealand ECE teachers' beliefs practice within a range of different contexts, professional development and centre settings. There is also a need for further research on teachers' understanding of children's learning goals, interests, and assessment practices. This might include teachers' use of the Te Whāriki and the Kei tua o te Pae resource and Learning Stories.

Findings from this research supported previously made claims that the relationship between teacher beliefs and practice was complex. Teachers' beliefs were influential in 
regard to their role during learning through play. While it was beyond the scope of this research to investigate teachers' learning experience, all their professional learning and development experience further research into these aspects would make valuable contributions to the field of learning through play (Wood \& Bennett, 2000). A weakness of small-scale qualitative research is the generalisability. Therefore, I acknowledge using a quantitative method to investigate ECE teachers' beliefs and practice about learning through play and assessment approach through surveys/questionnaires administered to a larger sample of teachers across New Zealand, would afford complementary information by extending the scope and breadth that to allow generalisation to a wider population.

\section{Contribution of the Current Research}

This study responds to calls for contributions to knowledge of learning through play related to teachers' beliefs and practice. A significant contribution of this research is the rich and detailed description of teachers' beliefs and practices, which has highlighted the complexity of the implementation of learning through play. In-depth studies of ECE teachers in their contexts illustrate the fact that teachers' experiences, knowledge and skills about learning through skill do not completely fit with current learning through play (Sturgess, 2003). There have been calls for continued contribution to the field of learning through play (Hedges \& Cooper, 2014; Farquhar, 2012; Hedges \& Cooper, 2016; McLachlan et al., 2017; McLachlan, 2018; Zhang, 2017).

This research and analysis make a valuable contribution to the field of play and learning in the ECE setting, with respect to identifying a gap between teachers' understanding about play and their practice. It draws attention to teachers' multifaceted understanding of the definitions and understanding of learning through play and what their role should be, which may restrict them from fully utilising play as a learning tool and limit their assessment strategies in identifying learning. 


\section{Concluding Statement}

My research has shown that teachers' espoused beliefs about learning through play and assessment and their practice are at times inconsistent. While I found that teachers report beliefs about their practice which have some similarities, the way those beliefs were enacted into practice showed considerable variations. It is apparent that effective learning through play cannot be implemented without addressing teachers' embedded beliefs that impact their practice and their understanding about play-based pedagogies and assessments in particular. Teachers need professional learning and development support if they are to acquire this knowledge have the opportunity to make such changes. 


\section{REFERENCES}

Absolum, M., Flockton, L., Hattie, J., Hipkins, R., \& Reid, I. (2009). Directions for assessment in New Zealand (DANZ): Developing students' assessment capabilities. Retrieved from http://assessment.tki.org.nz/Assessmentin-theclassroom/Directions-for-assessment-in-New-ZealandDANZreport.

Alcock, S., \& Stobbs, N. (Eds.). (2019). Rethinking play as pedagogy. New York NY: Routledge.

Alvestad, M., Duncan, J., \& Berge, A. (2009). New Zealand ECE teachers talk about Te Whāriki. New Zealand Journal of Teachers' Work, 6(1), 3-19.

Aras, S. (2016). Free play in early childhood education: A phenomenological study. Early Child Development and Care, 186(7), 1173-1184.

Ash, D., \& Wells, G. (2006). Dialogic inquiry in classroom and museum. In Z. Bekerman, N. Burbules, \& D. Silberman-Keller (Eds.), Learning in places (pp. 35-54). New York: Peter Lang.

Ashiabi, G. S. (2007). Play in the preschool classroom: Its socioemotional significance and the teacher's role in play. Early Childhood Education Journal, 35(2), 199-207.

Bailey R. (2002). Playing social chess: Children's play and social intelligence. Early Years, 22: 163-173.

Baker, F. S. (2014). Teachers' views on play-based practice in Abu Dhabi Kindergartens. International Journal of Early Years Education 22 (3), 271286.

Baldwin, J., \& Baldwin, J. (1978). Reinforcement theories of exploration, play, and psychosocial growth. In E. O. Smith (Ed.), Social play in primates (pp. 231253). New York NY: Academic Press.

Bateman, A., \& Church, A. (2017). Children's use of objects in an early year playground. European Early Childhood Education Research Journal, 25(1), 55-71. 
Bandura, A. (1986). The explanatory and predictive scope of self-efficacy theory. Journal of Social and Clinical Psychology, 4(3), 359-373.

Bell, N. N. (1990). Theorising practice in early childhood education. (Master of Arts in Education), Massey University, Palmerston North, New Zealand.

Bennett, N. (1997). Teaching through play: Teachers' thinking and classroom practice. United Kingdom: McGraw-Hill Education.

Berg, B. L. (2007). Qualitative research methods for the social sciences (6th ed.). Boston: Allyn and Bacon.

Bergen, D. (2002). The role of pretend play in children's cognitive development. Early Childhood Research \& Practice, 4(1), n1.

Berk, L. E. (2001). Awakening children's minds: How parents and teachers can make a difference. New York: Oxford University Press.

Bernstein, B. (2000). Pedagogy, symbolic control and identity: Theory, research, critique. (Revised ed.). London, England: Taylor \& Francis.

Black, P., \& Wiliam, D. (1998). Inside the black box. Raising standards through classroom assessment. The Phi Delta Kappan, 80(2), 139-148.

Blaiklock, K. (2010). Te Whāriki, the New Zealand early childhood curriculum: Is it effective?. International Journal of Early Years Education, 18(3), 201-212.

Blaiklock, K. (2013). What are children learning in early childhood education in New Zealand?. Australasian Journal of Early Childhood, 38(2), 51-56.

Barkatsas, A., \& Malone, J. (2005). A typology of mathematics teachers' beliefs about teaching and learning mathematics and instructional practices. Mathematics Education Research Journal, 17(2), 69-90.

Bjorklund, C. (2008). Toddlers' opportunities to learn math. International Journal of Early Childhood, 40, 81-95.

Blaiklock, K. (2018). Te Whāriki: The New Zealand early childhood curriculum. In International handbook of early childhood education (pp. 1075-1093). Springer, Dordrecht. 
Bodrova, E. (2003). Vygotsky and Montessori: One dream, two visions. Montessori Life, 15(1), 30-32.

Bodrova, E. (2008). Make-believe play versus academic skills: A Vygotskian approach to today's dilemma of early childhood education. European early childhood education research journal, 16(3), 357-369.

Bodrova, E., Germeroth, C., \& Leong, D. J. (2013). Play and self-regulation: Lessons from Vygotsky. American Journal of Play, 6, 111-123.

Bogdan, R. C., \& Biklen, S. K. (2007). Qualitative research for education: An introduction to theories and methods, Boston MA: Pearson.

Borich, G. (1999). Dimensions of self that influence effective teaching. In R. P. Lipka, \& T. M. Brinthaupt (Eds.) The role of self in teacher development (pp. 92-117). Albany: State University of New York Press.

Bubikova-Moan, J., Næss Hjetland, H., \& Wollscheid, S. (2019). ECE teachers' views on play-based learning: a systematic review. European Early Childhood Education Research Journal, 27(6), 776-800.

Bredekamp S., Copple C. (1997). Developmentally appropriate practice in early childhood programs (Revised ed.). Washington, DC: National Association for the Education of Young Children.

Broadfoot, P. (2007). An introduction to assessment. New York, NY: Continuum

Brooker, L. (2001). Interviewing children. Doing early childhood research: International perspectives on theory and practice, 162-177.

Bronfenbrenner, U. (1979). The ecology of human development. Cambridge, MA: Harvard University Press.

Bronfenbrenner, U., \& Morris, P.A. (2006). The bioecological model of human development. In R.M. Lerner \& W. Damon (Eds.), Handbook of child psychology (6th edn, pp. 793-828). Hoboken, NH: John Wiley \& Sons.

Brown, G. T. L. (2004). Teachers' conceptions of assessment: Implications for policy and professional development. Assessment in Education: Principles, Policy and Practice, 11(3), 301-318. 
Brown, M. C., McNeil, N. M., \& Glenberg, A. M. (2009). Using concreteness in education: Real problems, potential solutions. Child Development Perspectives, 3, 160-164.

Bruner, J. (1972). The nature and uses of immaturity. American Psychologist, 27, 687-708.

Bryman, A. (2008), The end of the paradigm wars?. In P. Alasuutari, L. Bickman, L. \& J.Brannen, (Eds.), The SAGE Handbook of Social Research Methods (pp. 13-25), London: Sage.

Cagiltay, K., Kara, N., \& Aydin, C. C. (2014). Smart toy-based learning. In Handbook of research on educational communications and technology (pp. 703-711). Springer, New York, NY.

Carr, M. (1998a). Assessing children's experiences in early childhood. Final report to the Ministry of Education, part one. Wellington: Ministry of Education Research Division.

Carr, M. (1998b). Project for assessing children's experiences. Final report to the Ministry of Education, part two: Five case studies. Wellington: Ministry of Education Research Division.

Carr, M. (2001). Assessment in early childhood settings: Learning stories. London: Paul Chapman.

Carr, M., \& Lee, W. (2012). Learning Stories: Constructing Learner Identities in Early Education. London: Sage.

Carr, M., \& Lee, W. (2019). Learning stories in practice. SAGE Publications Limited. Carr, M., May, H., \& Podmore, V. (2000). Learning and teaching stories: Action research on evaluation in early childhood education. Final report to the Ministry of Education. Wellington: New Zealand Council for Educational Research.

Carr, M., May, H., Podmore, V. N., Cubey, P., Hatherly, A., \& Macartney, B. (2002). Learning and teaching stories: Action research on evaluation in early childhood in Aotearoa-New Zealand. European Early Childhood Education 
Research Journal, 10(2), 115-125.

Charlesworth, R., Hart, C., Burts, D., \& Hernandez, S. (1991). Kindergarten teachers' beliefs and practices. Early Childhood Development and Care, 70, 17-35.

Chazan, S. (2002). Profiles of play: Assessing and observing structure and process in play therapy. Jessica Kingsley Publishers.

Clark, P., \& Kragler, S. (2005). The impact of including writing materials in early childhood classrooms on the early literacy development of children from lowincome families. Early Child Development and Care, 175(4), 285-301.

Claxton, G. \& Carr, M. (2004). A framework for teaching learning: The dynamics of disposition. Early Years: Journal of International Research and Development, 24(1): 87-98.

Cohen, L., Manion, L., \& Morrison, K. (2007). Research methods in education (6 ed.). New York, NY: Routledge-Falmer.

Cole, P. M. (1985). Display rules and the socialization of affective displays. In G. Zivin (Ed.), The development of expressive behaviour (pp. 269-290). New York: Academic Press.

Cole, P. M. \& Wertsch, J.V. (1996) Beyond the individual--social antinomy in discussions of Piaget and Vygotsky. Human Development 39, 250-256.

Cooper, M., \& Hedges, H. (2014). Beyond participation: What we learned from Hunter about collaboration with Pasifika children and families. Contemporary Issues in Early Childhood, 15(2), 165-175.

Coplan, R. J., Rubin, K.H., \& Findlay, L.C. (2006). Social and nonsocial play. In D.P. Fromberg \& D. Bergen (Eds.), Play from birth to twelve: Contexts, perspectives, and meanings (2nd ed., pp. 75-86). New York: Garland.

Cowie, B. (2009). Teacher formative assessment decision making: A consideration of principles and consequences. Assessment Matters, 1, 47-63.

Cowie, B., \& Mitchell, L. (2015). Equity as family/Whānau opportunities for participation in formative assessment. Assessment Matters, Special Issue 8 , 
$119-141$.

Creswell, J. W. (2007). Qualitative inquiry \& research design: Choosing among five approaches (2nd ed.). Thousand Oaks, California: Sage.

Creswell, J. W. (2009). Research design: Qualitative and mixed methods approaches. Thousand Oaks, London: Sage.

Cutter-Mackenzie, A., \& Edwards, S. (2013). Toward a model for early childhood environmental education: Foregrounding, developing, and connecting knowledge through play-based learning. The Journal of Environmental Education, 44(3), 195-213.

Cutter-Mackenzie, A., Edwards, S., Moore, D., \& Boyd, W. (2014). Young children's play and environmental education in early childhood education. New York: Springer Science \& Business Media.

Dalli, C. (2011). A curriculum of open possibilities: A New Zealand kindergarten teacher's view of professional practice. Early Years, 31(3), 229-243.

Delamont, S. (1992). Fieldwork in educational settings. London: Falmer Press.

DeLuca, C., Pyle, A., Valiquette, A., \& LaPointe-McEwan, D. (2020). New Directions for Kindergarten Education: Embedding Assessment in Play-Based Learning. The Elementary School Journal, 120(3), 000-000.

Denham, S. S. (1998). Emotional development in young children. New York: Guilford.

Denscombe, M. (2003). The good research guide for small-scale social research projects, (2nd ed.). Maidenhead: Open University Press.

Denscombe, M. (2007). The good research guide: For small-scale social research projects (3rd ed.). Buckingham, UK: Open University Press.

Denzin, N. K., \& Lincoln, Y. S. (2008). The landscape of qualitative research. London: Sage

Denzin, N. K., \& Lincoln, Y. S. (2011). The SAGE handbook of qualitative research ( $4^{\text {th }}$ ed.). Thousand Oaks, CA: Sage 
DeVries, R. (2006) Games with Rules. In D.P. Fromberg and D. Bergen (Eds) Play from Birth to Twelve, 2nd Ed. Abingdon, Oxon: Routledge.

Dewey, J. (1910). How we think. Boston: D C Heath and Company.

Dewey, J. (1966). Democracy and Education. New York: Free Press.

Dockett, S. (2011). The challenge of play for early educators. In S. Rogers (Ed.), Rethinking play and pedagogy in early childhood education: Concepts, contexts and cultures. London: Routledge

Dockett, S., \& Perry, B. (1996). Young children's construction of knowledge. Australian Journal of Early Childhood, 21(4), 6-12.

Drummond, M. J. (1995). Assessing children's learning. London, England: David Fulton.

Durden, T. and Dangel, J.R. 2008. Teacher-involved conversations with young children during small group activity. Early Years, 28(3), 251-66.

Eberle, S. G. (2014). The Elements of Play. Journal of Play 6 (2): 214-233.

Edmiston, B. (2017). Dialogic dramatic playing with young children. The Routledge International Handbook of Early Childhood Play, 137.

Education Review Office. (2007). The quality of assessment in early childhood education. Wellington, New Zealand: Crown Publishers.

Edwards, S. (2016). New concepts of play and the problem of technology, digital media and popular-culture integration with play-based learning in early childhood education. Technology, Pedagogy and Education, 25(4), 513-532.

Edwards, S. (2017). Play-based learning and intentional teaching: Forever different?. Australasian Journal of Early Childhood, 42(2), 4-11.

Edwards, S., \& Cutter-Mackenzie, A. (2013). Pedagogical play types: What do they suggest for learning about sustainability in early childhood education? International Journal of Early Childhood, 45(3), 327-346.

Edwards, S., Cutter-Mackenzie, A., Moore, D., \& Boyd, W. (2017). Finding the 
balance: A play-framework for play-based learning and intentional teaching in early childhood education. Every Child, 23(1), 14-15. Canberra, ACT: Early Childhood Australia

Ertmer, P. A., \& Newby, T. J. (1993). Behaviorism, cognitivism, constructivism:

Comparing critical features from an instructional design perspective.

Performance improvement quarterly, 6(4), 50-72.

Farquhar, S. (2003). Quality teaching early foundations: Best evidence synthesis.

Wellington, New Zealand: Ministry of Education.

Farquhar, S. (2012). Narrative Identity and Early Childhood Education. Educational Philosophy and Theory, 44(3), 289-301.

Fang, Z. (1996). A review of research on teacher beliefs and practices. Educational Research, 38(1): 47-65.

Fisher, K., Hirsh-Pasek, K., Golinkoff, R. M., Singer, D. G., \& Berk, L. (2011). Playing around in school: Implications for learning and educational policy.

Fleer, M. (2009). Supporting scientific conceptual consciousness or learning in 'a roundabout way'in play-based contexts. International Journal of Science Education, 31(8), 1069-1089.

Fromberg, D. (1986). Play. In C. Seefeldt (Ed.), Early childhood curriculum: A review of current research (pp. 48-84). New York: Teachers College Press.

Garegae, K. G. (2016). Teachers' professed beliefs about the nature of mathematics, its teaching and learning: Inconsistencies among data from different instruments. Philosophy of Mathematics Education Journal, 30, 1-18.

Glover, A. (1999). The role of play in development and learning. In E. (Main Ed.) \& E. Jones (Consulting Ed.). Child's play: Revisiting play in early childhood settings (pp. 5-15). Baltimore: Paul H. Brooks Publishing Co.

Gol-Guven, M. (2017). Play and flow: Children's culture and adults' role. Journal of Early Childhood Studies 1(2), 247-261.

Guba, E., \& Lincoln, Y. (1985). Effective evaluation: improving the usefulness of evaluation results through responses and naturalist approaches. San 
Francisco: Jossey-Bass.

Guskey, T. R. (2002). Professional development and teacher change. Teachers and teaching, 8(3), 381-391.

Hadley, E (2002). Playful disruptions. Early Years, 22, 9-17,

Haggerty, M., Loveridge, J., \& Alcock, S. (2020). Shifts in policy and practice in early childhood curriculum priorities in Aotearoa-New Zealand: Entanglements of possibility and risk. Policy futures in Education. Sage

Halberstadt, A. G., Denham S. A., \& Dunsmore J. C. (2001). Affective social competence. Social Development, 10, 79-119.

Hall, N. (1991). Play and the emergence of literacy. In J. Christie (Ed.), Play and early literacy development (pp.3-25). Albany, New York: State University of New York Press.

Hall, N. (2000). Literacy, Play, and Authentic Experience. In K. Roskos \& J. Christie (Eds.). Play and literacy in early childhood: Research from multiple perspectives (pp.189-204). New Jersey: Erlbaum.

Hargreaves, E. (2007). The validity of collaborative assessment for learning. Assessment in education: Principles, policy \& practice, 14(2), 185-199.

Hegde, A. V., \& Cassidy, D. J. (2009). Kindergarten teachers' perspectives on developmentally appropriate practices (DAP): A study conducted in Mumbai (India)." Journal of Research in Childhood Education, 23(3): 367-381.

Hegde, A. V., Chisato, S., Crane-Mitchell, L., \& Averett, P. (2014). Japanese nursery and kindergarten teachers' beliefs and practices regarding developmentally appropriate practices. International Journal of Early Years Education, 22(3), 301-314.

Hedges, H. (2000). Teaching in Early Childhood: Time to merge Constructivist views so learning through play equals teaching through play. Australasian Journal of Early Childhood, 25(4), 16-21.

Hedges, H. (2011). Connecting 'snippets of knowledge': Teachers' understandings of 
the concept of working theories. Early Years, 31(3), 271-284.

Hedges, H. (2013). The future of Te Whāriki: Political, pedagogical and professional concerns. Weaving Te Whāriki: Aotearoa New Zealand's early childhood curriculum document in theory and practice, 277-298.

Hedges, H. (2014). Children's content learning in play provision: Competing tensions and future possibilities. The Sage handbook of play and learning in early childhood, 192-203.

Hedges, H., \& Cooper, M. (2016). Inquiring minds: Theorizing children's interests. Journal of Curriculum Studies, 48(3), 303-322.

Hedges, H., \& Cooper, M. (2018). Relational play-based pedagogy: Theorising a core practice in early childhood education. Teachers and Teaching, 24(4), 369-383.

Hedges, H., \& Cullen, J. (2005). Subject knowledge in early childhood curriculum and pedagogy: Beliefs and practice. Contemporary Issues in Early Childhood, 6(1): 66-79.

Hedges, H., \& Jones, S. (2012). Children's working theories. The neglected sibling of Te Whāriki's learning outcomes. Early Childhood Folio, 16(1), 34-39.

Henniger, M. L. (1994). Planning for outdoor play. Young children, 49(4), 10-15.

Hill, M., Cowie, B., Gilmore, A., \& Smith, L.F. (2010). Preparing assessment capable teachers: What should preservice teachers know and be able to do? Assessment Matters, 2, 43-64.

Hitz, R., \& Wright, D. (1988). Kindergarten issues: A practitioners' survey. Principal, $21,28-30$.

Hooker, T. (2019). Using ePortfolios in early childhood education: Recalling, reconnecting, restarting and learning. Journal of Early Childhood Research, 17(4), 376-391.

Howard, J. (2010). Early years practitioners' perceptions of play: An exploration of theoretical understanding, planning and involvement, confidence and barriers 
to practice. Educational \& Child Psychology, 27(4):91-102.

Hughes, F. P. (1999). Children, play, and development (3rd ed.). Needham Heights, MA: Allyn \& Bacon.

Hughes, F. P. (2003). Spontaneous play in the 21st century. Contemporary perspectives on play in early childhood education, 21-39.

Hutchin, V. (1996). Tracking significant achievement in the early years. London, England: Hodder Education.

Jones B., Reynolds G. (1992). The play's the thing: Teachers' roles in children's play. New York: Teachers College Press

Johnson, J. E. (1998). Play development from ages 4-8. In D. P. Fromberg \& D.Bergen (Eds.), Play from birth to twelve and beyond: Contexts, perspectives, and meanings (pp. 146-153). New York: Garland Publishing, Inc.

Kagan, D. M. (1992). Professional growth among preservice and beginning teachers. Review of educational research, 62(2), 129-169.

Kagan, S. L. (1990). Children's play: The journey from theory to practice. In E. S. Klugman, \& S. Smilansky (Eds.), Children's play and learning: Perspectives and policy implications (pp.173-187). New York: Teachers College Press.

Kirschner, P. A., Sweller, J., \& Clark, R. E. (2006). Why minimal guidance during instruction does not work. Educational Psychologist, 41, 75-86.

Kirkby, J., Keary, A., \& Walsh, L. (2018). The impact of Australian policy shifts on early childhood teachers' understandings of intentional teaching. European Early Childhood Education Research Journal, 26(5), 674-687

Knauf, H. (2020). Documentation Strategies: Pedagogical Documentation from the Perspective of Early Childhood Teachers in New Zealand and Germany. Early Childhood Education Journal, 48(1), 11-19.

Lee, W., M. Carr, M., Soutar, B., \& Mitchell, L. (2012). Understanding the Te Whāriki approach: Early Years Education in practice. London: Routledge.

Lee, K., Courtney, M., McGlashan, A., Neveldsen, P., \& Toso, M. (2019). Initial 
teacher education students' perceptions of technology and technology education in New Zealand. International Journal of Technology and Design Education, 1-22.

Leggett, N., \& Ford, M. A. (2010). Fine balance: Understanding the roles educators and children play as intentional teachers and intentional learners within the early years learning framework. Australasian Journal of Early Childhood. 38(4):42-50.

Leggett, N., \& Ford, M. (2013). A fine balance: Understanding the roles educators and children play as intentional teachers and intentional learners within the Early Years Learning Framework. Australasian Journal of Early Childhood, 38(4), 4250.

Lillard, A. S., Matthew D. L., Emily J. H., Rebecca A. D., Eric D. S., and Carolyn M. P. (2013). The Impact of pretend play on children's development: A Review of the Evidence. Psychological Bulletin, 139(1): 1.

Lincoln, Y. S., \& Guba, E. G. (1985). Naturalistic inquiry. Newbury Park, CA: Sage.

Lindsey E. W., Colwell M. J. (2003). Preschoolers' emotional competence: Links to pretend and physical play. Child Study Journal, 33, 39-52

Marcon, R. A. (2002). Moving up the Grades: Relationship between preschool model and later school success. Early Childhood Research \& Practice, 4(1), n1.

Mawson, B. (2011). Playcentre parent educators' assessment practice. New Zealand Research in Early Childhood Education, 14, 39-51.

McArdle, P. (2001). Children's play. Child: Care, Health and Development, 27, 509514.

McArdle, F., Grieshaber, S., \& Sumsion, J. (2019). Play meets early childhood teacher education. The Australian Educational Researcher, 46(1), 155-175.

McCarty, F., Abbott-Shim, M., \& Lambert, R. (2001). The relationship between teacher beliefs and practices, and Head Start classroom quality. Early Education and Development, 12(2), 225-238.

McLachlan, C. (2013, 4th December). Children's learning and development in New Zealand: Physical, cognitive and socio-emotional perspectives. Inaugural Professorial Address, Palmerston North, New Zealand. 
McLachlan, C. (2018). Te Whāriki revisited: How approaches to assessment can make valued learning visible. He Kupu, 5(3), 45-56.

McLachlan, C., Smith, J., McLaughlin, T., Ali, A., Conlon, C., Mugridge, O., \& Foster, S. (2017). Development of teachers' knowledge and skills in implementing a physical education curriculum: A New Zealand early childhood intervention study. International Journal of Early Childhood, 49(2), 211-228.

McLachlan-Smith, C. (1996). Emergent literacy in New Zealand kindergartens: An examination of policy and practice. (Doctor of Philosophy), Massey University, Palmerston North, New Zealand

Martlew, J., Stephen, C., \& Ellis, J. (2011). Play in the primary school classroom? The experience of teachers supporting children's learning through a new pedagogy. Early Years 31 (1), 71-83.

Meckley, A. (2002). Observing children's play: Mindful methods. International Toy Research Association, London, 12.

Merriam, S. B. (2001). Qualitative research and case study applications in education: Revised and expanded from case study research in education. San Francisco: Jossey-Bass.

Mertens, D. M., \& Hesse-Biber, S. (2013). Mixed methods and credibility of evidence in evaluation. New directions for evaluation, 2013(138), 5-13.

Miller, L., \& Smith, A. P. (2004). Practitioners' beliefs and children's experiences of literacy in four early years settings. Early Years, 24(2), 121-133.

Miles, M.B., and Huberman, A. M. (1994). Qualitative data analysis: An expanded sourcebook. Thousand Oaks, California: Sage Publications.

Ministry of Education. (1993). Te Whāriki. Draft Guidelines for Developmentally Appropriate Programs in Early Childhood Services. Wellington: Learning Media Ltd.

Ministry of education (1996). Te Wha"riki. He Wha"riki Ma"tauranga mo"nga" Mokopuna o Aotearoa: Early childhood curriculum. Wellington: Learning 
Media Ltd. Retrieved from http://www.education.govt.nz/earlychildhood/teaching-and-learning/ece-curriculum/tewhariki/.

Ministry of Education. (2004a). Kei Tua o te Pae. Assessment for learning: Early childhood exemplars. Book 1 - An introduction to Kei Tua o te Pae. Wellington, New Zealand: Learning Media.

Ministry of Education. (2004b). Kei Tua o te Pae. Assessment for learning: Early childhood exemplars. Book 4 - Children contributing to their own assessment. Wellington, New Zealand:Author.

Ministry of Education. (2004c). Kei Tua o te Pae. Assessment for learning: Early childhood exemplars. Book 9 - Inclusive assessment. Wellington, New Zealand: Author.

Ministry of Education. (2004/2007/2009). Kei Tua o te Pae. Assessment for learning: Early childhood exemplars. Wellington, New Zealand: Author. Ministry of Education. (2011). Ministry of Education position paper: Assessment (Schooling sector). Ko te whārangi takotoranga ārunga, ā te tāhuhu I te mātauranga, te matekitenga. Wellington, New Zealand: Learning Media Ltd. Ministry of Education. (2017). Te Whāriki. He Whāriki mātauranga mō ngā mokopuna o Aotearoa. Early childhood curriculum (2nd ed.). Wellington, New Zealand: Learning Media Ltd.

Moon, K., \& Reifel, S. (2008). Play and literacy learning in a diverse language prekindergarten classroom. Contemporary Issues in Early Childhood, 9(1), 49-65.

Moore, D., Edwards, S., Cutter-Mackenzie, A., \& Boyd, W. (2014). Play-based learning in early childhood education. In Young Children's Play and Environmental Education in Early Childhood Education (pp. 9-24). Cham: Springer.

Mordock, J. B. (1997). Ego supportive play therapy for children who lack imaginative play: Building defenses. International Journal of Play Therapy, 6(1), 23.

Mueller, J. J., \& File, N. (Eds.). (2019). Curriculum in Early Childhood Education: Re- 
examined, Reclaimed, Renewed. Routledge.

Myck-Wayne, J. (2010). In defense of play: Beginning the dialog about the power of play. Young Exceptional Children 13(4), 14-23.

Nicolopoulou, A., Cortina, K. S., Ilgaz, H., Cates, C. B., \& de Sá, A. B. (2015). Using a narrative-and play-based activity to promote low-income preschoolers' oral language, emergent literacy, and social competence. Early childhood research quarterly, 31, 147-162.

Nuttall, J. (2003). Exploring the role of the teacher within Te Whāriki: Some possibilities and constraints. In J. Nuttall (Ed.), Weaving Te Whāriki. Aotearoa New Zealand's early childhood curriculum document in theory and practice (pp. 161-186). Wellington, New Zealand: New Zealand Council for Educational Research.

O'Donoghue, T. A. (2007). Planning your qualitative research project: An introduction to interpretive research in education. Taylor \& Francis.

Olsen, A., \& Sumsion, J. (2000). Early childhood teacher practices regarding the use of dramatic play in K-2 classrooms. Paper presented at the Annual Conference of the Australian Association for Research in Education. Sydney: AARE.

Osanloo, A., \& Grant, C. (2016). Understanding, selecting, and integrating a theoretical framework in dissertation research: Creating the blueprint for your "house". Administrative issues journal: connecting education, practice, and research, 4(2), 7.

Oppermann, E., Brunner, M., \& Anders, Y. (2019). The interplay between preschool teachers' science self-efficacy beliefs, their teaching practices, and girls' and boys' early science motivation. Learning and Individual Differences, 70, 86-99.

Pajares, M. F. (1992). Teachers' beliefs and educational research: Cleaning up a messy construct. Review of educational research, 62(3), 307-332.

Pang, E., \& Simoncelli-Bulak, L. (2017). Benefits of Play-based Learning in the Kindergarten Classroom. Success in High-Need Schools Journal, 13(1), 23. Panksepp, J. (1993). Rough and tumble play: A fundamental brain process. In K. 
MacDonald (Ed.), Parent-child play: Descriptions \& implications (pp. 147184). Albany: State University of New York Press.

Parke, R. D., Roisman, G. I., \& Rose, A. J. (2019). Social development. John Wiley \& Sons.

Parker, A., \& Neuharth-Pritchett, S. (2006). Developmentally appropriate practice in kindergarten: Factors shaping teacher beliefs and practice. Journal of research in childhood education, 21(1), 65-78.

Patton, M. Q. (2002). Qualitative research and evaluation methods. Thousand Oaks, CA: Sage.

Pellegrini, A. D. (1995). A longitudinal study of boys' rough-and-tumble play and dominance during early adolescence. Journal of Applied Developmental Psychology, 16(1), 77-93.

Pellegrini, A. D. (1988). Elementary-school children's rough-and-tumble play and social competence. Developmental Psychology, 24(6), 802.

Pellegrini, A. D. (2006). Recess: Its role in education and development. Psychology Press.

Pellegrini, A. D. (2008). The roles of aggressive and affiliative behaviors in resource control: A behavioral ecological perspective. Developmental Review, 28, 461487.

Pellegrini, A. D. (2009). The role of play in human development. New York: Oxford University Press.

Pellegrini, A. D. (2013). Play. Oxford University Press.

Pelligrini, A. D., Smith P. K. (1998). Physical play activity: The nature and function of a neglected aspect of play. Child Development, 69, 577-584.

Pellegrini, A. D., \& Gustafson, K. (2005). Boys' and girls' uses of objects for exploration, play, and tools in early childhood. In: Pellegrini AD, Smith PK, eds. The Nature of Play: Great Apes and Humans (pp. 113-138). New York, NY: Guilford Press. 
Piaget, J. (1951), Play, dreams and imitation in childhood, London: Heinemann.

Piaget, J. (1955), The child's construction of reality, London: Routledge \& Kegan Paul

Piaget, J. (1973). To understand is to invent: The future of Education. New York: Grossman.

Samuelsson, I. P., \& Carlsson, M. A. (2008). The playing learning child: Towards a pedagogy of early childhood. Scandinavian journal of educational research, 52(6), 623-641.

Pyle, A., \& Bigelow, A. (2015). Play in Kindergarten: An interview and observational study in three Canadian classrooms. Early Childhood Education Journal 43 (5): 385-393.

Pyle, A., \& Danniels, E. A. (2017). Continuum of play-based learning: The role of the teacher in play-based pedagogy and the fear of hijacking play. Early Education and Development, 28(3):274-289.

Ramani, G. B., \& Siegler, R. S. (2008). Promoting broad and stable improvements in low-income children's numerical knowledge through playing number board games. Child Development, 79, 375-394.

Ranz-Smith, D. J. (2007). Teacher perception of play: In leaving no child behind are teachers leaving childhood behind?. Early education and development, 18(2), 271-303.

Raver, C. C. (2002). Emotions matter: Making the case for the role of young children's emotional development for early school readiness. SRCD Social Policy Report, 16(3), 3-18.

Raymond, A. M. (1997). Inconsistency between a beginning elementary school teacher's mathematics beliefs and teaching practice. Journal for research in mathematics education, 550-576.

Reese, E., Gunn, A., Bateman, A., \& Carr, M. (2019). Teacher-child talk about learning stories in New Zealand: a strategy for eliciting children's complex language. Early Years, 1-16.

Reynolds, B. (2007). Researching authenticity: The relationship between 
kindergarten teachers' espoused theories and their actual practices. NZ Research in Early Childhood Education, 10, 155-167.

Richardson, V. (1996). The role of attitudes and beliefs in learning to teach. Handbook of research on teacher education, 2, 102-119.

Robertson, N., Morrissey, A. M., \& Rouse, E. (2018). Play-based learning can set your child up for success at school and beyond. Science Education News, 67(1), 50.

Rogoff, B. (1993). Children's guided participation and participatory appropriation in sociocultural activity. In R. H. Wozniak \& K. W. Fischer (Eds.), Development in context: Acting and thinking in specific environment. (pp. 121-153). Hillsdale, NJ: Erlbaum.

Rossman, G. B., \& Rallis, S. F. (2012). Learning in the field: An introduction to qualitative research. Thousand Oaks, CA: Sage.

Roussou, M. (2004). Learning by doing and learning through play: an exploration of interactivity in virtual environments for children. Computers in Entertainment (CIE), 2 (1), 10-10.

Rubin, K. H. (1986). Play, peer interaction and social development. In A.W. Gottfried \& C. C. Brown (Eds.), Play interactions: The contributions of play materials and parental involvement to children's development (pp. 163-174). Lexington, MA: Heath.

Samuelsson, I P., \& Johansson, E. (2006). Play and Learning—Inseparable Dimensions in Preschool Practice. Early Child Development and Care 176(1): 47-65.

Saracho, O. N. (2015). Historical and contemporary evaluations of early childhood programmes. Early Child Development and Care, 185(8), 1255-1267.

Saracho, O. N., \& Spodek, B. (2006). Young children's literacy-related play. Early child development and care, 176(7), 707-721.

Sarama, J., \& Clements, D. H. (2009). "Concrete" computer manipulatives in 
mathematics education. Child Development Perspectives, 3, 145-150.

Sarter, M. (2006). The consequences of atheoretical, task-driven experimentation:

Theoretical comment on Paban, Chambon, Jaffard, and Alescio-Lavtier (2005), 120(2), 493-494.

Schwandt, T. A. (2000). Three epistemological stances for qualitative inquiry. In N.

K. Denzin \& Y. Lincoln (Eds.), Handbook of qualitative research (pp. 189214). Thousand Oaks, CA: Sage.

Schwartzman, H. (1978). Transformations: The anthropology of children's play. New York: Plenum.

Scharer, J. H. (2017). Supporting young children's learning in a dramatic play environment. Journal of Childhood Studies, 42(3), 62.

Seidman, I. (2006). Interviewing as qualitative research: A guide for researchers in education and the social sciences (3rd ed.). New York, NY: Teachers College Press.

Seidman, I. (2013). Interviewing as qualitative research. A guide for researchers in education \& the social sciences (4th ed.). New York, NY: Teachers College Press.

Selmi, A. M., Gallagher, R. J., \& Mora-Flores, E. R. (2014). Early childhood curriculum for all learnerSelm: Integrating play and literacy activities. SAGE Publications.

Sherley, B. M. (2011). Kindergarten and new entrant teachers' beliefs and practices in mathematics teaching and learning. (Doctor of Philosophy in Mathematics Education), Victoria University of Wellington, Wellington, New Zealand.

Sherwood, S. A. S., \& Reifel, S. (2013). Valuable and unessential: The paradox of preservice teachers' beliefs about the role of play in learning. Journal of Research in Childhood Education 27 (3): 267-282.

Skinner, B. F. (1938). The behaviour of organisms. Englewood Cliffs, NJ: PrenticeHall.

Smilansky, S. (1968). The effects of Sociodramatic Play on Disadvantaged 
Preschool children. New York: Wiley.

Smilansky, S., \& Shefatya, L. (1990). Facilitating play: A medium for promoting cognitive, socio-emotional and academic development in young children. Silver Springs, MD: Psychosocial and Educational Publications

Smith, P. K. (1988). Children's play and its role in early development: A re-evaluation of the 'Play Ethos'. In: A. D. Pellegrini (Eds), Psychological Bases for Early education. (207-226). New York, NY: John Wiley \& Sons Ltd.

Smith, P. K., \& Pellegrini, A. (2008). Learning through play. Encyclopedia on early childhood development, 24(8), 61.

Smith, L., \& Shepard, M. (1988a). Escalating academic demand in kindergarten: Counterproductive policies. The Elementary School Journal, 89, 135-145.

Smith, L., \& Shepard, M. (1988b). Kindergarten readiness and retention: A qualitative study of teachers' beliefs and practices. American Educational Research Journal, 25(3), 307-333.

Sroufe, L. A. (1997). Emotional competence: The organization of emotional life in the early years. Cambridge, UK: Cambridge University Press.

Stake, R. E (2006). Multiple case study analysis. New York, NY: Guilford Press.

Stake, R. E. (2010). Qualitative research: Studying how things work. New York: The Guilford Press.

Steele, M. M. (2005). Teaching students with learning disabilities: Constructivism or behaviorism?. Current Issues in Education, 8.

Stipek, D. J., \& Weisz, J. R. (1981). Perceived personal control and academic achievement. Review of Educational Research, 51(1), 101-137.

Stipek, D., \& Byler, P. (1997). Early childhood education teachers: Do they practice what they preach? Early Childhood Research Quarterly, 12, 305-325.

Stipek, D., Feiler, R., Daniels, D., \& Milburn, S. (1995). Effects of different instructional approaches on young children's achievement and motivation. Child development, 66(1), 209-223. 
Stipek, D. J., Karen, B. G., Julie, M. S., \& Valanne, L. M. (2001). Teachers' beliefs and practices related to mathematics instruction. Teaching and teacher education 17(2), 213-226.

Strauss, A. L., \& Corbin J. (1994). Basics of qualitative research. Thousand Oaks: Sage Publications.

Stuart, D., Aitken, H., Gould, K., \& Meade, A. (2008). Evaluation of the implementation of Kei Tua o te Pae. Assessment for learning: Early childhood exemplars: Impact evaluation of the Kei Tua o te Pae 2006 professional development. Report prepared for the Ministry of Education. Wellington, New Zealand: Cognition Consulting.

Sturgess, J. (2003). A model describing play as a child-chosen activity-is this still valid in contemporary Australia? Australian Occupational Therapy Journal, 50, 104-108.

Sutton-Smith, B. (1966). Piaget on play: A critique. Psychological Review, 73, 104110.

Taguma, M., Litjens, I., \& Makowiecki, K. (2012). Quality Matters in Early Childhood Education and Care: New Zealand 2012.

Thorndike, E. L. (1913). Educational psychology: volume II: the psychology of learning. New York: Teachers College Columbia University

Tsao, Y. L. (2008). Using guided play to enhance children's conversation, creativity and competence in literacy. Education, 128(3), 515-520.

Vartuli, S. (1999). How early childhood teacher beliefs vary across grade level. Early childhood research quarterly, 14(4), 489-514.

Vig, S. (2007). Young children's object play: A window on development. Journal of Developmental and Physical Disabilities, 19(3), 201-215.

Vygotsky, L. S. (1967). Play and its role in the mental development of the child. Soviet psychology, 5(3), 6-18.

Vygotsky, L. S. (1978). Mind in society: The development of higher psychological processes. Cambridge, MA: Harvard University Press. 
Wallerstedt, C., \& Pramling, N. (2012). Learning to play in a goal-directed practice. Early Years, 32, 5-15.

Waters, J., \& Rekers, A. (2019). Young Children's Outdoor Play-Based Learning. Encyclopedia on Early Childhood Development.

Watson, J. B. (1913). Psychology as the behaviorist views it. Psychological Review, 20, 158-177.

Wang, J., Elicker, J., McMullen, M., \& Mao, S. (2008). Chinese and American preschool teachers' beliefs about early childhood curriculum. Early Child Development and Care, 178(3), 227-249.

Weisleder, A., \& Fernald, A. (2013). Talking to children matters: Early language experience strengthens processing and builds vocabulary. Psychological Science, 24, 2143-2152.

Wentzel, K. R., \& Asher, S. R. (1995). The academic lives of neglected, rejected, popular, and controversial children. Child Development, 66,754-763.

Weisberg, D. S., Hirsh-Pasek, K., Golinkoff, R. M., Kittredge, A. K., \& Klahr, D. (2016). Guided play: Principles and practices. Current Directions in Psychological Science, 25(3), 177-182.

White, J., Ellis, F., O’Malley, A., Rockel, J., Stover, S. \& Toso, M. (2008). Play and learning in Aotearoa New Zealand Early Childhood Education. In I. PramlingSamuelson, \& M. Fleer (Eds). (pp. 19-50). Play and learning in early childhood settings: International perspectives. Dordrecht etc: Springer.

Wolfgang, C. H., Stannard, L. L., \& Jones, I. (2001). Block play performance among preschoolers as a predictor of later school achievement in mathematics. Journal of Research in Childhood Education, 15(2), 173-180.

Wilks, A. (1993). Assessment of children in early childhood centres. Report to the Ministry of Education. (Master of Education), Massey University, Palmerston North, New Zealand.

Wood, E. (2007). New directions in play: consensus or collision?. Education 3-13, 35(4), 309-320. 
Wood, E. (2009). Developing a pedagogy of play. Early childhood education: Society and culture, 27-38. Sage, London

Wood, E., \& Attfield, J. (2005). Play, learning and the early childhood curriculum. Sage.

Wood, E., \& Bennett, N. (2000). Changing theories, changing practice: Exploring early childhood teachers' professional learning. Teaching and teacher education, 16(5-6), 635-647.

Yin, R. K. (2009). Case study research: Design and methods (4th ed.). California: Sage.

Youniss, J. (2017). The nature of social development: A conceptual discussion of cognition. In Issues in childhood social development (pp. 203-227). Routledge.

Zeichner, K., \& Gore, J. (1989). Teacher socialization. In W. Houston (Ed) Handbook of research on teacher education (pp. 329-348). New York: MacMillan.

Zhang, Q. (2017). Emergent literacy as sociocultural practice: How well do New Zealand parents fit with Te Whāriki?. Journal of Early Childhood Literacy, 17(1), 69-91. 


\section{APPENDICES}

\section{APPENDIX A}

\section{Appendix A1}

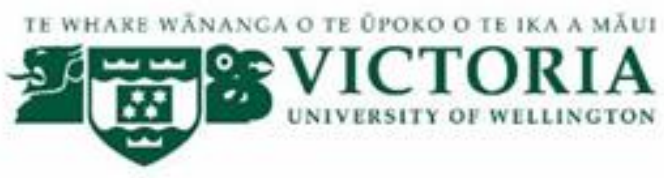

\section{HOW DO EARLY CHILDHOOD TEACHERS' BELIEFS ON CHILDREN'S LEARNING THROUGH PLAY IMPACT THEIR APPROACH TO ASSESSMENT?}

\section{INFORMATION SHEET FOR ORGANISATIONS/HEAD TEACHERS}

Thank you for your interest in this project. Please read this information before deciding whether or not your organisation will take part. If you decide to participate, thank you. If you decide not to take part, thank you for considering my request.

\section{Who am I?}

My name is Matthew James and I am a Masters student in Education at Victoria University of Wellington. This research project is work towards my thesis.

\section{What is the aim of the project?}

This project aims to explore the relationship between teachers' beliefs about the role of play children's learning and their approach to assessment. This study will involve three teachers from three different centres. The proposed research seeks to explore this relationship. More specifically the research seeks to explore and seek answers to the following questions:

1. What beliefs do early childhood teachers hold about role of play in children's learning?

2. How do early childhood teachers assess children's learning through play?

3. How do teachers' beliefs about the role of play in children's learning impact their approach to assessment?

Your organisation's participation will support this research by providing insight into teachers' beliefs regarding play and learning, as well as assessment practices. This research has been approved by the Victoria University of Wellington Human Ethics Committee (27689). 


\section{How can you help?}

If you agree to be involved, I would like to interview and observe one teacher participant who volunteered to take part and ask them questions about their beliefs regarding play and learning, and how these beliefs impact assessment practices. The interview will take 40 to 60 minutes with a follow interview of around 30-40 minutes. The interviews will take place at a location of their convenience. I would like to audio record the interview with the permission of the teacher participant and write it up later. The interviews will be confidential, meaning that I will know who participated, but the identity of the teacher participant will be protected.

My aim is to observe three play-based sessions in your centre, in which the teacher participant is involved in. Observations will focus on interpersonal interactions between the teacher participant and children during play-centred activities. I plan to allow 40-60 minutes for each observation, which will occur over the course of September to October 2019. The observations will not have any impact on the teacher participant's work. Each individual participant, including children and their parents, will be asked to provide consent before their involvement in the research. I will take written running records during the observations. The observations will be confidential, meaning that I will know who participated, but the identities of the participants will be protected.

\section{What will happen to the information the participants give?}

Participation in this research is confidential. This means that the researcher named below will be aware of the identity of your organisation, but your organisation will not be identified in any reports, presentations, or public documentation.

Only my supervisor, the transcriber and I will read the notes or transcript of the interview. The interview transcripts, summaries and any recordings/survey data will be kept securely and destroyed on 28 March 2025.

\section{What will the project produce?}

The information from my research will be used in my Masters thesis, and with participant permission, may be presented at conferences and used in publications. I will also provide your organisation with a report summarising the results of the research.

\section{If you accept this invitation, what are the rights of your organisation?}

You do not have to accept this invitation if you don't want to. If you do decide that your organisation will participate, you have the right to:

- $\quad$ ask any questions about the study at any time;

- $\quad$ withdraw your organisation's participation from the study before 15 November 2019, however, individual participants retain the right to decide if their data will be withdrawn;

- $\quad$ be able to read a summary report of this research. 
If you have any questions or problems, who can you contact?

If you have any questions, either now or in the future, please feel free to contact either:

\section{Researcher:}

Matthew James

jamesmatt@myvuw.ac.nz

\section{Supervisor:}

Maggie Haggerty

Senior Lecturer

School of Education

044639624

maggie.haggerty@vuw.ac.nz

\section{Human Ethics Committee information}

If you have any concerns about the ethical conduct of the research, you may contact the Victoria University HEC Convenor: Dr Judith Loveridge. Email hec@vuw.ac.nz or telephone +64-4-463 6028. 


\section{Appendix A2}

TE WHARE WÃNANGA O TE ŨPOKO O TE IKA A MÃUI

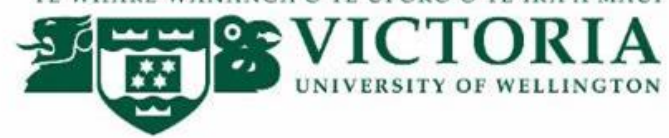

\section{HOW DO EARLY CHILDHOOD TEACHERS' BELIEFS ON CHILDREN'S LEARNING THROUGH PLAY IMPACT THEIR APPROACH TO ASSESSMENT?}

\section{CONSENT TO PARTICIPATE (ORGANISATION)}

This consent form will be held for 5 years.

Researcher: Matthew James, School of Education, Victoria University of Wellington.

I have read the Information Sheet and the project has been explained to me. My questions have been answered to my satisfaction. I understand that I can ask further questions at any time.

I agree that my organisation will take part.

ınderstand that:

I may withdraw this organisation from this study at any point before 15 November 2019, and the information provided by members of the organisation will be returned to them/or destroyed.

Any information the participants provide will be included in a final report but the transcripts, observation notes and recordings will be kept confidential to the researcher and the supervisor.

The identities of the participants will not remain confidential to the researcher.

I understand that the results will be used for a Masters thesis and/or academic publications and/or presented to conferences.

The name of my organisation will not be used in reports and utmost care will be taken not to disclose any information that would identify the organisation.

I would like to receive a copy of the final report and have added my email address below. 
Signature of participant:

Name of participant:

Date:

Contact details: 


\section{Appendix A3}

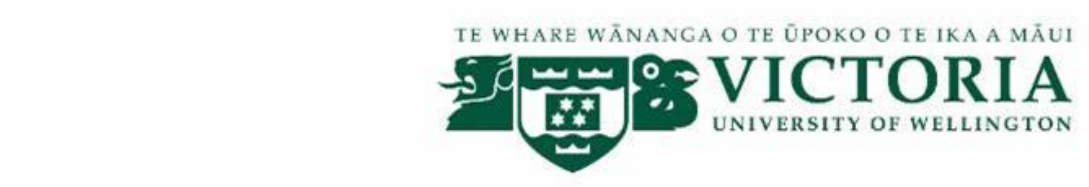

\section{HOW DO EARLY CHILDHOOD TEACHERS' BELIEFS ON CHILDREN'S LEARNING THROUGH PLAY IMPACT THEIR APPROACH TO ASSESSMENT?}

\section{INFORMATION SHEET FOR TEACHER PARTICIPANTS FOR INTERVIEWS AND OBSERVATIONS}

You are invited to take part in this research. Please read this information before deciding whether or not to take part. If you decide to participate, thank you. If you decide not to participate, thank you for considering this request.

\section{Who am I?}

My name is Matthew James and I am a Masters student in Education at Victoria University of Wellington, and also work as an early childhood teacher. This research project is work towards my thesis.

\section{What is the aim of the project?}

This project aims to research the relationship between teachers' beliefs about the role of play children's learning and their approach to assessment. More specifically the research seeks to explore and seek answers to the following questions:

1. What beliefs do early childhood teachers hold about role of play in children's learning?

2. How do early childhood teachers assess children's learning through play?

3. How do teachers' beliefs about the role of play in children's learning impact their approach to assessment?

Your participation will support this research by providing information on beliefs regarding play and learning, and how these beliefs impact assessment practices. This research has been approved by the Victoria University of Wellington Human Ethics Committee (27689).

\section{How can you help?}

You have been invited to participate because of your work as an early childhood teacher. If you agree to take part, I will interview you at a location of your convenience. I will ask you questions about your beliefs on play and learning, and how these beliefs impact your assessment practices. The interview will take 40 to 60 minutes, with post observation questions of around 30 to 40 minutes. I will audio record the 
interview with your permission and write it up later. You can choose to not answer any question or stop the interview at any time, without giving a reason.

I would also like to observe you in your work with children during play-centred activities. Observations will focus on interpersonal interactions between teachers and children during play-centred activities, and I will also seek permission from children and the consent of their parents prior to commencing observations. Observations will be recorded by a handwritten running record. I would like to conduct three observations of approximately 60 minutes, over September-October 2019. You can withdraw from the study by contacting me at any time before 15 November 2019. If you withdraw, the information you provided will be destroyed or returned to you.

\section{What will happen to the information you give?}

This research is confidential. This means that I as the researcher named below will be aware of your identity, but the research data will be combined, and your identity will not be revealed in any reports, presentations, or public documentation. However, you should be aware that in small projects your identity might be obvious to others in your community.

Only my supervisor and I will read the notes or transcript of the interview. The interview transcripts, summaries and any recordings will be kept securely and destroyed five years after the completion of the thesis.

\section{What will the project produce?}

The information from my research will be used in my Masters dissertation, and with permission, may possibly being used for future presentations.

\section{If you accept this invitation, what are your rights as a research participant?}

You do not have to accept this invitation if you don't want to. If you do decide to participate, you have the right to:

- $\quad$ choose not to answer any question;

- $\quad$ ask for the recorder to be turned off at any time during the interview;

- $\quad$ withdraw from the study before 15 November 2019;

- $\quad$ ask any questions about the study at any time;

- $\quad$ receive a copy of your interview recording;

- $\quad$ receive a copy of your interview transcript;

- $\quad$ read over and comment on a written summary of your interview and observations;

- $\quad$ be able to read any reports of this research by emailing the researcher to request a copy.

If you have any questions or problems, who can you contact?

If you have any questions, either now or in the future, please feel free to contact: 
Researcher:

Matthew James

jamesmatt@myvuw.ac.nz
Supervisor:

Maggie Haggerty

Senior Lecturer

School of Education

044639624

maggie.haggerty@vuw.ac.nz

\section{Human Ethics Committee information}

If you have any concerns about the ethical conduct of the research, you may contact the Victoria University HEC Convenor: Dr Judith Loveridge. Email hec@vuw.ac.nz or telephone +64-4-463 6028. 


\section{Appendix A4}

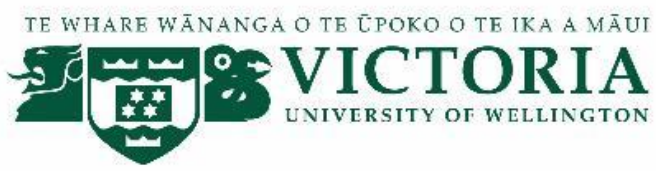

\section{HOW DO EARLY CHILDHOOD TEACHERS' BELIEFS ON CHILDREN'S LEARNING THROUGH PLAY IMPACT THEIR APPROACH TO ASSESSMENT?}

\section{CONSENT TO INTERVIEW AND OBSERVE}

This consent form will be held for five years, until 28 March 2025.

Researcher: Matthew James, School of Education, Victoria University of Wellington.

I have read the Information Sheet and the project has been explained to me. My questions have been answered to my satisfaction. I understand that I can ask further questions at any time.

I agree to take part in an audio recorded interview.

I agree to take part in observations.

understand that:

I may withdraw from this study at any point before 15 Oct 2019, and any information that I have provided will be returned to me or destroyed.

The identifiable information I have provided will be destroyed on 28 March 2025.

Any information I provide will be kept confidential to the researcher and the supervisor.

I give permission for the information collected as part of the research to be used for a Masters thesis and/or academic publications and/or presented to conferences.

I understand that the recordings and running records will be kept confidential to the researcher and the supervisor.

[I understand that organisational consent has been provided and the organisation will not be named in any of the reports].

My name will not be used in reports and utmost care will be taken not to disclose any information that would identify me. 
I would like a copy of the recording of my interview:

I would like a copy of the transcript of my interview and observation:

I would like a summary of my interview and observation:

I would like to receive a copy of the final report and have added my email address below.
Yes $\square \quad N$

Yes $\square \quad N$

Yes $\square \quad N$

Yes $\square \quad N$

Signature of participant:

Name of participant:

Date:

Contact details: 


\section{Appendix A5}

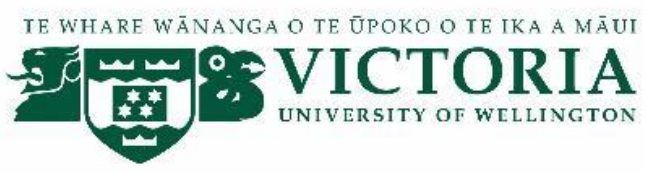

\section{HOW DO EARLY CHILDHOOD TEACHERS' BELIEFS ON CHILDREN'S LEARNING THROUGH PLAY IMPACT THEIR APPROACH TO ASSESSMENT?}

\section{INFORMATION SHEET FOR PARENTS/GUARDIANS}

You are invited to take part in this research. Please read this information before deciding whether or not to take part. If you decide to participate, thank you. If you decide not to participate, thank you for considering this request.

\section{Who am I?}

My name is Matthew James and I am a Masters student in Education at Victoria University of Wellington, and also work as an early childhood teacher. This research project is work towards my thesis.

\section{What is the aim of the project?}

This project aims to research the relationship between teachers' beliefs about the role of play children's learning and their approach to assessment. More specifically the research seeks to explore and seek answers to the following questions:

1. What beliefs do early childhood teachers hold about role of play in children's learning?

2. How do early childhood teachers assess children's learning through play?

3. How do teachers' beliefs about the role of play in children's learning impact their approach to assessment?

Your participation will support this research by providing information on beliefs regarding play and learning, and how these beliefs impact assessment practices. This research has been approved by the Victoria University of Wellington Human Ethics Committee (27689).

How can you help?

I would also like to observe your child as they interact with their teacher in play based activities. Observations will focus on interpersonal interactions between teachers and children during playcentred activities, and I will also seek permission from your child prior to commencing observations. Observations will be recorded by a handwritten running record. I would like to conduct three observations of approximately 60 minutes, over September-October 2019. You can withdraw from the study by contacting me at any time before 15 November 2019. If you withdraw your child, the information gathered on them will be destroyed. 


\section{What will happen to the information you give?}

This research is confidential. This means that I as the researcher named below will be aware of your child's identity, but the research data will be combined, and your child's identity will not be revealed in any reports, presentations, or public documentation.

Only my supervisor and I will read the observation notes. The observation notes and summaries will be kept securely and destroyed five years after the completion of the thesis.

\section{What will the project produce?}

The information from my research will be used in my Masters dissertation, and with permission, may possibly being used for future presentations and publications.

\section{If you accept this invitation, what are your rights as a research participant?}

You do not have to accept this invitation if you don't want to. If you do decide to participate, you have the right to:

- $\quad$ withdraw your child from the study before 15 November 2019;

- $\quad$ ask any questions about the study at any time;

- $\quad$ be able to read a summary of this research reports which will be made available to your Early

Childhood Education Centre.

If you have any questions or problems, who can you contact?

If you have any questions, either now or in the future, please feel free to contact either:

Researcher:

Matthew James

jamesmatt@myvuw.ac.nz

\section{Supervisor:}

Maggie Haggerty

Senior Lecturer

School of Education

044639624

maggie.haggerty@vuw.ac.nz

\section{Human Ethics Committee information}

If you have any concerns about the ethical conduct of the research, you may contact the Victoria University HEC Convenor: Dr Judith Loveridge. Email hec@vuw.ac.nz or telephone +64-4-463 6028. 


\section{Appendix A6}

TE WHARE WĀNANGA O TE L̃POKO O TE IKA A MĀUT

\section{TH: VICTORIA \\ HOW DO EARLY CHILDHOOD TEACHERS' BELIEFS ON CHILDREN'S LEARNING THROUGH PLAY IMPACT THEIR APPROACH TO ASSESSMENT? \\ CONSENT FORM FOR PARENTS/GUARDIAN}

This consent form will be held for 5 years.

Researcher: Matthew James, School of Education, Victoria University of Wellington.

- I have read the Information Sheet and the project has been explained to me. My questions have been answered to my satisfaction. I understand that I can ask further questions at any time.

- I agree for my child to take part in an observation, with a written recording being taken.

inderstand that:

nay withdraw my child from this study at any point before 15 November 2019 and any information that I have provided will be returned to me or destroyed.

- $\quad$ The identifiable information gathered will be destroyed on 28 March 2025.

- Any information gathered will be kept confidential to the researcher and the supervisor.

- I understand that the findings may be used for a Masters thesis and with permission, possibly academic publications and/or presented to conferences.

- I understand that the observation notes will be kept confidential to the researcher and the supervisor.

- I understand that organisational consent has been provided and the organisation will not be named in any of the reports.

- My child's name will not be used in reports and utmost care will be taken not to disclose any information that would identify them.

Signature of parent:

Name of child:

Date: 
am happy for Matthew to watch me and my teacher playing together and write $\mathrm{d}_{\mathrm{t}}$ hat we do.

hild's name:

Zircle/colour appropriate face)
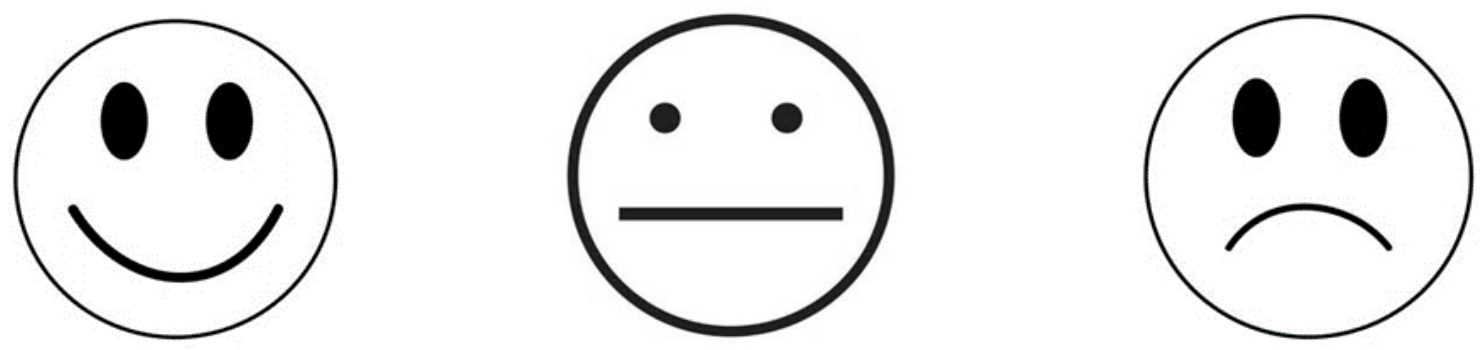


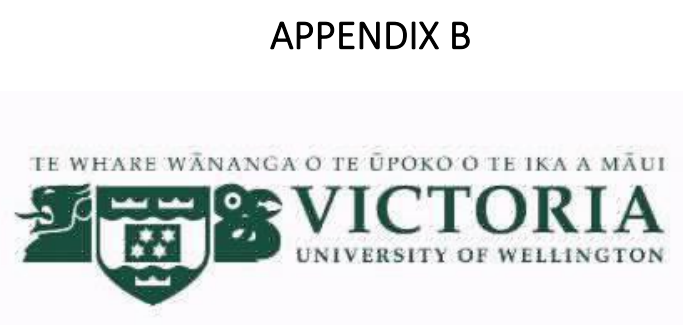

Researcher: Matthew James, School of Education, Victoria University of Wellington

\section{HOW DO EARLY CHILDHOOD TEACHERS' BELIEFS ON CHILDREN'S LEARNING THROUGH PLAY IMPACT THEIR APPROACH TO ASSESSMENT?}

\section{Questions for participants:}

- How would you define play?

- What is your understanding of the relationship between play and its role, if any, in children's learning?

- How would you define assessment?

- How did you learn about assessing children's learning?

- How do your assessments of children's learning inform your curriculum planning?

- Do children's play interests play a role in your curriculum planning? If so, how?

- What are some of the key elements you look for when observing children's play and learning?

- Are there any thoughts you would like to share regarding the research topic? 
Observations will be utilised alongside interviews to record rich, running record descriptions of interpersonal interactions and behaviours between the teachers and children, which will be used to explore and capture the themes and categories through thematic analysis (Mutch, 2005). My aim is to observe three play-based sessions in each centre, playing the role of a non-participant observer. Observations will focus on interpersonal interactions between teachers and children during playcentred activities. I plan to allow 40-60 minutes for each observation. Field notes will be used during the research to allow me to become more familiar with the different educational environments, through descriptions recorded describing the location and atmosphere where the observations of the play-based learning and interviews will be undertaken.

While undertaking this research, I will comply with Victoria University of Wellington's ethical principles and guidelines on human subjects by adhering to processes such as obtaining informed consent and minimizing risk to the participants by assuring their confidentiality. I will provide information to the participants of the purpose of the research and the nature of the observations and interviews. I will gain informed consent prior to research and will endeavour to ensure that all participants understand their rights to withdraw from the research.

\begin{tabular}{|l|l|}
\hline \multicolumn{2}{|l|}{ Observation notes (to be completed for each observation) } \\
\hline Date: & \\
\hline Location: & \\
\hline Start time: & \\
\hline End time: & \\
\hline Who was present: & \\
\hline
\end{tabular}




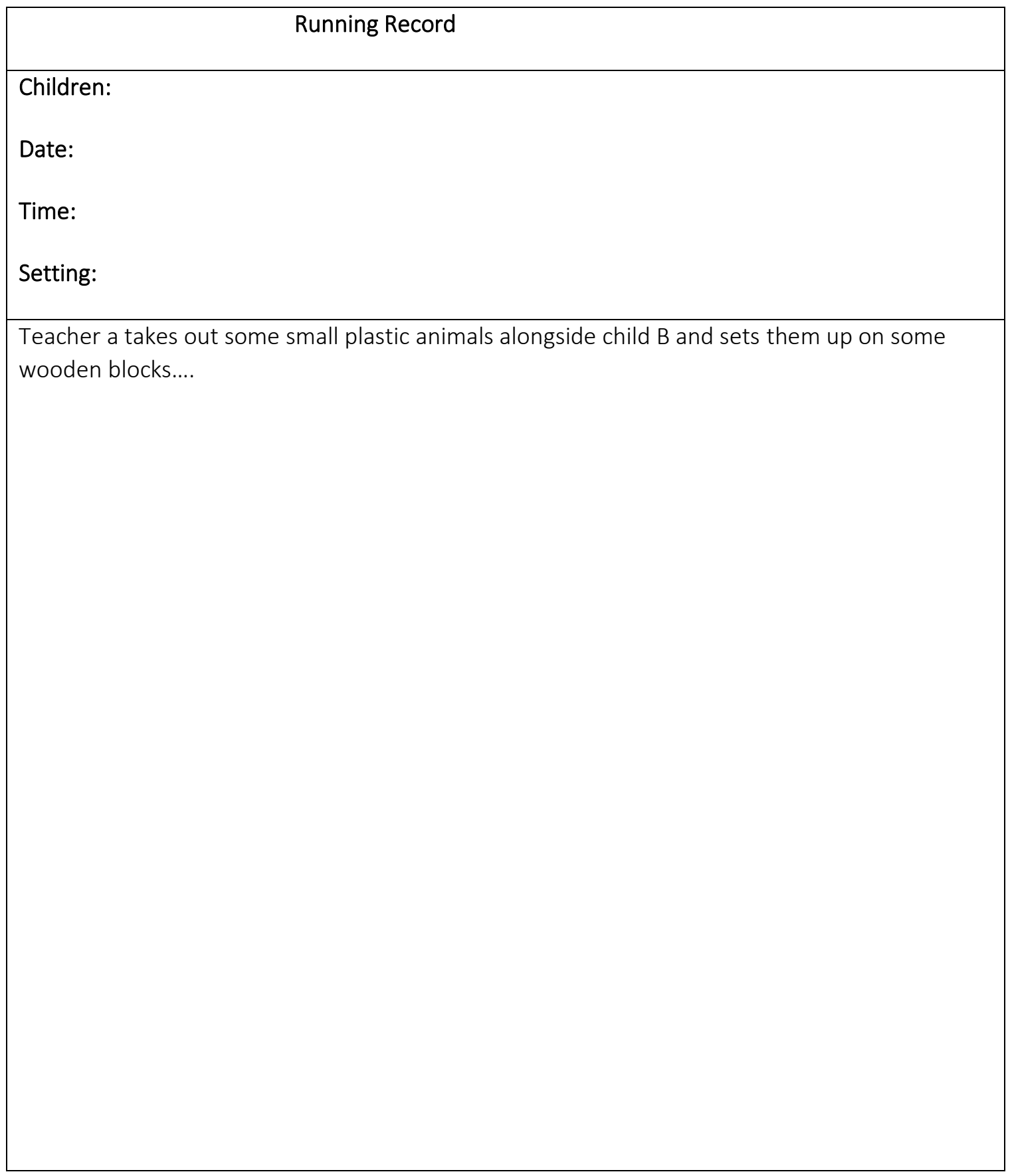




\section{APPENDIX C}

Interviews and observation schedule

\begin{tabular}{|l|l|l|}
\hline Participant & Data collection & Date \\
\hline Geoff & Interview & Monday 21 Oct, 2019 \\
\cline { 2 - 3 } & Observation Day 1 & Monday 21 Oct, 2019 \\
\cline { 2 - 3 } & Observation Day 2 & Tuesday 22 Oct, 2019 \\
\cline { 2 - 3 } & Observation Day 3 & Wednesday 23 Oct, 2019 \\
\cline { 2 - 3 } & Closing interview & Wednesday 23 Oct, 2019 \\
\hline \multirow{5}{*}{ Joyce } & Interview & Tuesday 22 Oct, 2019 \\
\cline { 2 - 3 } & Observation Day 1 & Tuesday 22 Oct, 2019 \\
\cline { 2 - 3 } & Observation Day 2 & Wednesday 23 Oct, 2019 \\
\cline { 2 - 3 } & Observation Day 3 & Thursday 24 Oct, 2019 \\
\cline { 2 - 3 } & Closing interview & Thursday 24 Oct, 2019 \\
\hline \multirow{5}{*}{ Rita } & Interview & Monday 27 Oct, 2019 \\
\cline { 2 - 3 } & Observation Day 1 & Monday 27 Oct, 2019 \\
\cline { 2 - 3 } & Observation Day 2 & Tuesday 28 Oct, 2019 \\
\cline { 2 - 3 } & Observation Day 3 & Wednesday 29 Oct, 2019 \\
\cline { 2 - 3 } & Closing interview & Wednesday 29 Oct, 2019 \\
\hline
\end{tabular}

